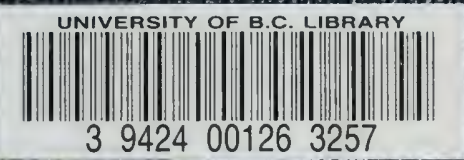

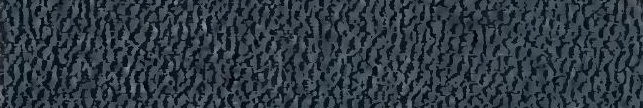

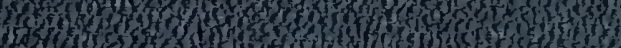
ate

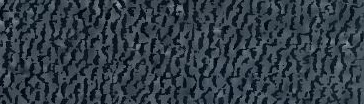
3.7. 3.

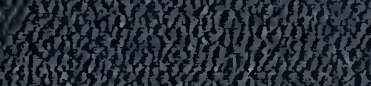
STORAGE ITEM PROCESSING LF 1 - F 200 U.B.C. LIBRARY 


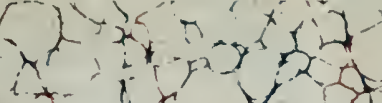

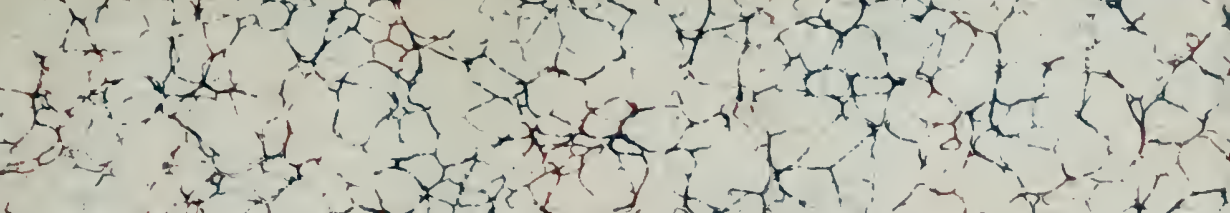

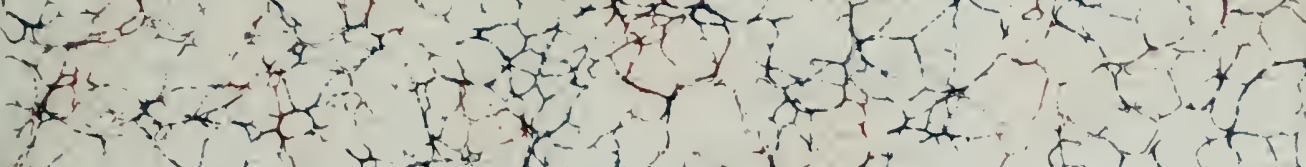

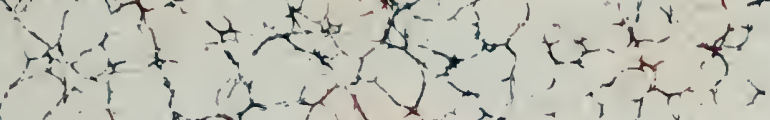

$2,1,7+4+2$

(1) and

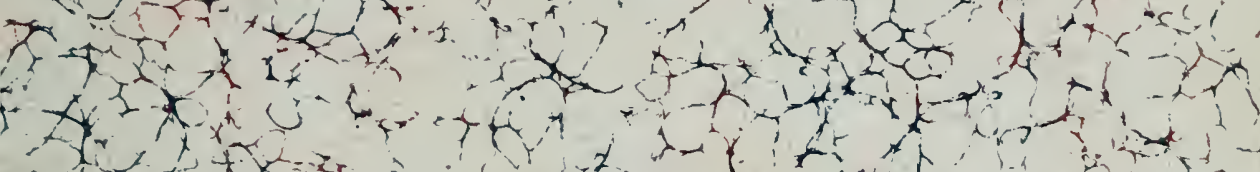

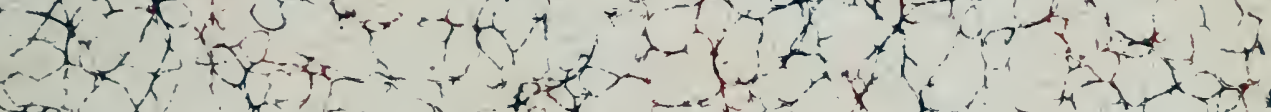

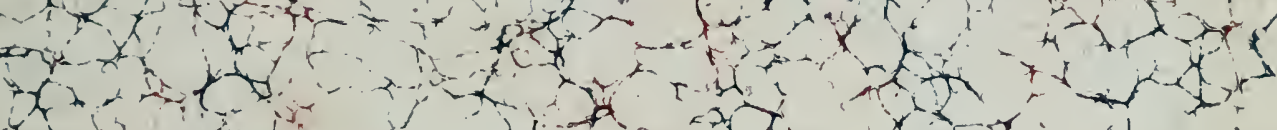
a d t tof a

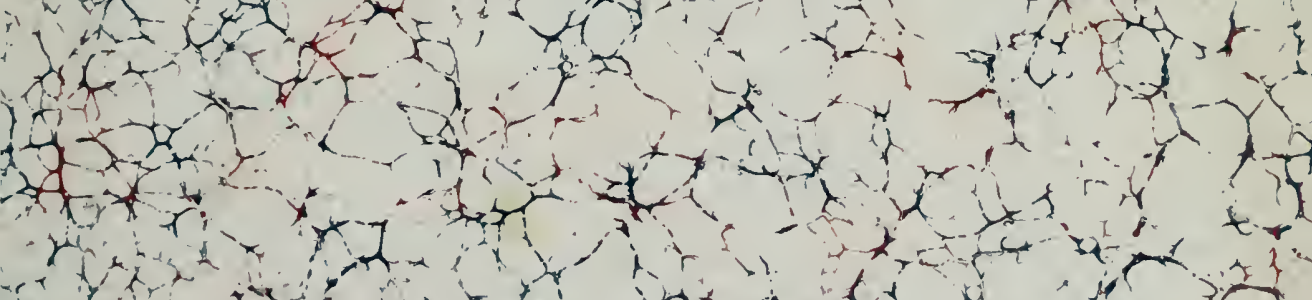
For at. $6 x+540+4$

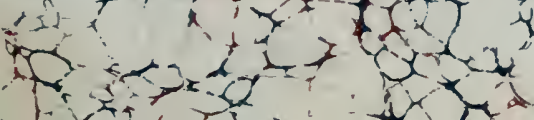

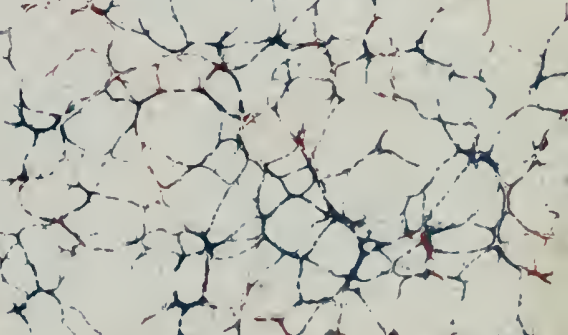




Digitized by the Internet Archive in 2010 with funding from

University of British Columbia Library 


\section{EL LIBRO}

DE LAS

AVES DE CAÇA. 



\section{EL LIBRO}

DE LAS

\section{A VES DE CACCA}

DEL CANCILLER

\section{PERO LOPEL DE AYALA}

CON LAS

\section{G L O S A S}

DEI, DUQUE DE ALBURQUERQLE

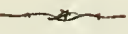

(PUblícalo la SOCIEDAd DE BIBLIófilos.)

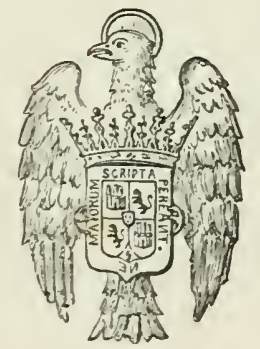

MADRID

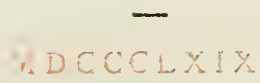


EJEMPLAR NÚM. 249.

IMPRENTA DE M. GALIANO, PI. IZA DE LOS MINISTERIOS, 2. 


\section{INTRODUCCION.}

Don Emilio Lafuente y Alcántara, á quien la Sociedad de Bibliófilos tenia encomendado el dar á luz con las ilustraciones convenientes el Libro de las Aves de Caza, del canciller Pero Lopez de Ayala, falleció en Archidona el 27 de Mayo del año próximo pasado, despues de una larga y penosa enfermedad, agravada, ya que no producida, por asíduas $\mathrm{y}$ constantes vigilias literarias.

Individuo de número de la Real Academia de la Historia, y bibliotecario de la Universidad Central, habia, jóven aún, dado muestras nada equívocas de su laboriosidad y talento, publicando en i 860 la obra intitulada: Inscripciones árabes de la $\mathrm{Al}$ hambra; en i 862 el Catálogo de los manuscritos adquiridos para el Estado durante la campaña de Africa; en el de 63 el Cancionero popular, y por 
último en el de 67 el Ajuar Machmua (r), ó coleccion de crónicas arábigas que para ilustrar la historia patria durante la dominacion musulmana, da á luz actualmente la ya citada Academia.

En el mismo año de i 867 la Sociedad de Bibliófilos cometia á su cuidado la publicacion de cierta crónica granadina, atribuida á Hernando de Baeza, y conservada en la Biblioteca del Escorial, á la que él mismo añadia otros fragmentos históricos de igual importancia bajo el título de Relaciones de algunos sucesos del Reyno de Granada.

Terminados dichos trabajos, que por sí solos bastarian á calificarle de crítico sagaz y orientalista entendido, ocupábase Lafuente en imprimir la presente obra y en allegar materiales para su ilustracion, cuando la muerte vino, segun queda dicho, á sorprenderle, en medio de tareas para él familiares y de su particular aficion; puesto que agotada ya la edicion de las Investigaciones sobre la Monteria, de su hermano D. Miguel (2), se proponia tambien reimprimirlas, corregidas y aumentadas.

Tirados ya los doce primeros pliegos del Libro del Canciller, y corregidos de primera los restantes, la obra hubo de quedar en tal estado, hasta encontrar quién tomase á su cargo la empresa, no

(1) Coleccion de obras arabigas de Historia y geografia, que publica la Real Academia de la Historia, tomo I.

(2) Investigaciones sobre la Montería y los demás ejercicios del Cazador, por D. Miguel Lafuente Alcántara. Madrid I $849,8 .^{\circ}$ 
fácil por cierto, de llevarla á cabo, atendida la confusion en que el difunto dejara sus papeles, y los ligerísimos apuntes que entre ellos se han hallado. Faltaba por completo la descripcion de los códices de que se habia valido; no estaba hecho, ni aún empezado, el Glosario de voces anticuadas, y en cuanto á la ilustracion de los textos, ya en su mayor parte impresos, y puntos discutibles que habia necesariamente de abrazar la introduccion ó prefacio á toda la obra, nada, absolutamente nada, ha parecido, siendo de presumir los conservase íntegros en la memoria.

Las cosas en este estado, cúpole al que suscribe interpretar los deseos y aspiraciones del difunto bibliófilo, estudiar asunto para él nuevo del todo, y suplir lo que faltaba para la terminacion del volúmen ya casi impreso en su totalidad, y tiradas tambien las cromo-litografias que debian ilustrarle.

La cetrería (I), ó caza con azores, fué ejercicio y pasatiempo de la gente noble durante la edad media. Sin hacer subir su invencion hasta Ulyses, como pretende algun escritor moderno (2), bien puede asegurarse que las naciones septentrionales, que salidas

(1) De accipiter que en latin significa "ave de rapiña" $y$ accipitraria, que es el arte de cazar con dichas aves, se formaria la palabra aceptrería ó cetrería á que otros asignan diferente orígen.

(2) Fernandez Ferreira, Arte de Caza de Altanería (Lisboa, 1616 , fólio 4.1 
de la Scytia invadieron el orbe romano á mediados del siglo $\mathrm{v}$, lo practicaban ya con increible ardor. Habla de ella Plinio ( $\mathrm{r}$ ), como constituyendo en sus dias principal entretenimiento de ciertas tribus bárbaras en las regiones de la Francia, y Canciani (2), cita varias leyes de los godos, de las cuales se deduce que un azor bien enseñado se vendia en aquel tiempo por un precio equivalente al de doce bueyes, y que al permitir á los acreedores el hacer traba y ejecucion de todos los bienes muebles ó inmuebles de un deudor, tan sólose exceptuaban del embargo el halcon y la espada (3).

Llenas están nuestras crónicas de anécdotas que manifiestan el alto aprecio que los monarcas castellanos hacian de un azor ó gavilan adiestrado para la caza de aves, y del ardor con que los nobles practicaban un ejercicio, que junto con el de las armas, parece haber constituido el solo y único divertimiento de la edad media. Verificábase la caza de cetrería con aves de rapiña, domesticadas y enseñadas á fuerza de industria y de paciencia. Llevábanse sobre la parte anterior del brazo, cubierto este de récia manopla de cuero reblandecido, llamada lua ó guante, para que las aceradas uñas del ave

(1) Histor, natur, lib. X, cap. 8.

(2) Barbarorum Leges antiquo, ley i 5., tít. III de las llamadas Ripuarias.

(3) Ley 16 de Ludovico Pio. 
no se embotasen. Si el azor se mostraba inquieto, ó no estaba aún bien endoctrinado, se le quitaba la luz por medio de una monterilla ó capuz llamado capirote, que le cubria enteramente la cabeza. Collares ricamente bordados en el cuello, y cascabeles de plata ó metal en las patas, engalanaban al neblí y daban mayor realce á su plumaje. Volada la perdiz, la garza ó el ánade, alzábase de pronto el capirote, enderezábase la vista del halcon, y éste se lanzaba con rápido vuelo en persecucion de su víctima que muy pronto bajaba á tierra oprimida entre sus garras. En su descenso el ave de rapiña describia círculos en el aire, y atenta al señuelo, volvia á posarse con su prison ó presa sobre el brazo del cazador. En casa el halcon era colocado sobre una percha ó alcándara con sus pihuelas de valdrés, y la lonja ó correa añadida á aquellas para darle mayor soltura en los movimientos. Si iba de viaje un vistoso alcahaz, á manera de gayola ó jaula, le encerraba con los demás de su especie.

Era esta caza un divertido espectáculo, al que asistian por lo comun montadas en mansos palafrenes, ó mulas de suave andadura, las damas de la comarca, las cuales gustaban de recibir en sus manos las aves campestres ó acuáticas que el neblí, el tagarote y el gavilan habian preso por los aires.

De presumir es que los árabes españoles, que tambien se mostraron aficionadísimos á este género de ejercicio, le aprendiesen de los persas que de 
muy antiguo le practicaron. En el shahnameh, de Ferdúsi, grande epopeya oriental en que se narra la historia de los antiguos reyes de Persia, es muy frecuente la mencion de halcones y azores domesticados para el uso y entretenimiento del hombre. Varios son los tratados de cetrería escritos en lenguas orientales que se conservan en la Biblioteca del Escorial ( I ; y como por otra parte es cosa sabida que los mejores halcones procedian de Tunez y de otras provincias de Berbería (2), y que los términos y voces usadas en aquel arte son en su mayor parte arábigos, no se necesitan mayores pruebas para establecer el hecho de que los árabes andaluces fuéron tan aficionados ó más que los españoles á este linaje de caza (3).

Natural era que las reglas y preceptos de un arte tan vulgarizada y esparcida, y que constituia, segun dejamos indicado, la principal ocupacion y

(1) Entre otros uno del granadino Isa ben Ali Al-azdí, de quien trata Casiri en su Biblioteca Arabico-Hispana Escurialensis, tom. 1, pág. 23 เ.

(2) Son de orígen arábigo las voces Alcaliai, Alcarabán, Alcotán, Alfancque, Arrexaca, A ₹ór, Bahari, Budalon, Sacre y otras que poirán verse en el Glosario de voces anticuadas puesto al fin de este tomo.

(3) Cuentan las historias arábigas que D. Rodrigo fue en extremo aficionado á lo caza de ares con azor, y que entre los presentes que el conde D. Julian, su feudatario, le traia cada año de Africa, lo que más le agradaba eran los azores, halcones y otras a ves de rapina amaestradas para la caza. 
recreo de la nobleza castellana, lograsen sus expositores y maestros, y así es que el sábio rey (i) don

(I) Es cuestion bastante debatida entre los eruditos la de si el Libro de Montería, publicado por Argote de Molina como de Alonso XI, debe ó no atribuirse al rey Sábio. Es evidente que el Sr. Lafuente se proponia tratarla, puesto que entre los escasos apuntes suyos que para esta publicacion se han hallado aparece la siguiente descripcion de dos códices escurialenses. "El señalado con la Y. ij i6, es ún tomo en fólio, escrito sobre papel ceptí, y letra del siglo xrv. Contiene las dos primeras partes del Libro de la Montería, que publicó Gonzalo Argote de Molina, atribuyéndole á D. Alonso X1, y que Rios en su Historia Crítica de la Literatura española asegura ser obra de D. Alonso el Sábio. Allí donde el publicado por Argote (en el capítulo I) dice: departese en tres libros, este que tenemos á la vista dice departese en dos libros, careciendo en efecto de la descripcion de los montes y tierras del señorío de Castilla. Concluye con una carta escrita á Alvar García, adelantado de Galicia, sobre una cuestion promovida con motivo de cierta montería.

Otro haý tambien en fólio señalado con la Y. ij, I9, en perga . mino avitelado, con las iniciales de oro, y letra del siglo xv. El título de letra más moderna, dice así: Libro de Montería del rey D. Alonso el Sábio. Este códice que está mal encuadernado y tiene todas las hojas trastrocadas, es el mismo que publicó Argote de Molina. El expresado D. José Amador de los Rios (Tomo III página 536 , nota) que dice haberle visto, afirma que no contiene másque dos partes, y que trata de la descripcion de los montes y tierras del señorío de Castilla que abundaban en caza; la noticia, empero, es inexacta; pues no sólo el códice contiene las partes publicadas por Argote sino que en el capítulo $10^{\circ}$ dice claramente: departese en tres partes, y no en dos, como dice el Y. ij. 16, el cual carece en efecto de la tercera. He cotejado este manuscrito con la publicacion de Argote y sólo he notado alguna variante en tal cual palabra, y el habérsele olvidado al editor el epígrafe del capítulo I que habla de los montes de tierra de Moya $v$ de 
Alfonso, primero, y más tarde su sobrino el infante D. Juan Manuel, escribieron los tratados de caza que conocemos, aunque incompletos, y en los cua. les además de la venacion ó montería se comprenderia á no dudarlo, la cetrería ó caza con azores.

En el siguiente siglo escribia el canciller Pedro Lopez de Ayala su Libro de las Aves de caça, e de sus plumages e dolencias e melecinamientos, el mismo que ahora se imprime por la primera vez.

Acerca de este caballero poco podrémos añadir á lo que su sobrino Fernan Perez de Guzman dijo ya en sus Generaciones y semblanzas, y reprodujo á fines del siglo pasado el erudito D. Rafael Floranes con notables adiciones (I). Nació en Victoria en 1332. Fuéron sus padres Fernan Perez de Ayala, adelantado del reino de Murcia, y doña Elvira Alvarez de Ceballos, señora de Escalante, Treceño, Arce y otros pueblos de la Montaña. Muy jóven aún, entró á servir al rey D. Pedro, cuyo doncel ó paje de lanza era ya en ı 353 . No debió, sin embargo, continuar mucho tiempo en su servicio, pues en el año siguiente de 1354 le vemos figurar

Cuenca, que debia entrar al fólio 55, columna segunda, antes de las palabras: La tierra de Val de Meca, etc... Tambien tiene este códice la carta á Alvar García. »

(I) Véase el tomo xix de la Coleccion de Documentos inéditos para la Historia de España, de los Sres. Salvá y Baranda, donde la obra del Sr. Floranes, intitulada: Vida literaria del Canciller Mayor de Castilla, Don Pedro Lope; de Ayala, restaurador de las letras en Castilla, se publicó por la primera vez. 
como doncel del infante D. Fernando de Aragon en las conferencias de Tejadillo, junto á Toro. En I 359 era capitan de una de las galeras que el rey D. Pedro hizo armar en Sevilla contra Aragon, y en i 360 alguacil mayor de Toledo.

Encendida en Castilla la guerra fratricida y civil, contienda que terminó en la muerte del rey D. Pedro y entronamiento de su hermano, el bastardo conde de Trastamara, Ayala continuó sirviendo á aquel, hasta el año de r 366 , siendo uno de los últimos señores que abandonaron su partido y se pasaron al contrario (I). Nombróle D. Enrique su alférez mayor del pendon de la Banda (2) en 1367 , pero derrotado en Nájera, hubo Ayala de caer prisionero en manos de los ingleses, si bien poco tiempo despues fué rescatado por gran suma de dineros. En 1374 le hallamos de alcalde mayor y merino de Vitoria, su ciudad natal, y dos años despues de embajador al rey de Aragon sobre el desafío de Juan Ramirez de Arellano (3). D. Juan I que empezó á reinar en i 379, y su hijo D. Enrique III le distinguieron sobremanera, nombrándole este último en ז 398 su canciller mayor en los reinos de Castilla. En la célebre batalla de Aljubarrota que aquel rey perdió en I 383, fué Ayala hecho prisionero

(I) Crónica, año 17 , cap. 4.

(2) Zurita, Enmiendas á las crónicas, etc., año is.

(3) Crónica de D. Pedro, fólio 35 r de la edicion de Toledo. 
y llevado á Portugal, donde y en el castillo de Oviedes, compuso el libro de cetrería de que ahora nos ocupamos.

Pero oigamos lo que Fernan Perez de Guzman dice en elogio suyo: (I) "Fué (dice) alto de cuerpo, e delgado e de buena persona; hombre de grand discreccion e autoridad e de grand consejo assi de paz como de guerra: ovo grand logar acerca de los reyes, en cuyo tiempo fue, ca seyendo moço fue bien quisio del rey Don Pedro, e despues del rey Don Enrique el segundo. Pasó por grandes fechos de guerra e de paz, ca fue preso dos veces, una en la batalla de Najera e otra en Aljubarrota. Fue de muy dulce condicion, e de buena conversacion é de grand conciencia, ca temia muncho á Dios. Amó muncho las sciencias; diose á los libros é historias, tanto que como quier que él fuesse asaz buen cavallero, é de grand discreccion en la plática del mundo, pero naturalmente fué muy inclinado á las sciencias, é con esto grand parte de su tiempo ocupara en leer é studiar, no en obras de Derecho, sinon en Filosofía é Historias. Por causa de él son conoscidos algunos libros en Castiella que antes non lo

(1) La cita se hace por un códice de las Generaciones y semblan ias, anterior á la primera edicion de Valladolid, que no conoció su editor y es del año 1512 , por Pedro Gumiel, en fólio, gótico á dos columnas. 
eran, ansí como el Tito Livio (I), que es la más notable hystoria romana; Las Caidas de los Príncipes (2); los Morales de Sant Gregorio (3); el Isidoro de Summo Bono (4); el Boecio (5); la hystoria de Troya $(6)$. El ordenó la hystoria de Castiella desde

(1) La primera edicion del Tito Livio, romanzado, es de Salamanca, I497, en fólio.

(2) Debió decir Caida y no Caidas. Continuó la obra Alfonso García de Santa María, á la sazon dean de Santiago y despues obispo de Búrgos.

La edicion príncipe es de Sevilla, 1495 , por Meynardo Ungut, Aleman y Lançalao Polono, en fólio.

(3) Flores de Morales de Job, ó sea Coleccion de sentencias entresacadas de los mismos Morales de Sant Gregorio. Hállase csta obra en el Escorial y habla de ella Rios, tomo v, pág. I I1.

(4) De Summo Bono sive de Sententiis, por Isidoro de Sevilla.

(5) La vision de Severino Boecio, intitulada: De consolatione philosophio, logró varias traducciones castellanas, siendo la primera de ellas esta de Ayala, que no se ha impreso nunca, y que Rios señala como existente en la biblioteca de Osuna (tomo v, p. I I2). Otra hay hecha por Fr. Anton Ginebreda, maestro en santa theología, del órden de predicadores de Barcelona, que se imprimió en Tolosa de Francia, por Enrique Mayer á 4 de Julio de I 488 , en fól. got. á 2 col. de 74 hojas, y 8 preliminares sin foliar.

(6) De la Crónica Troyana, traduccion del Excidium Troja o De casu civitatis Troie, pues bajo ambos títulos era conocido en la edad media este libro caballeresco, no se conserva, que sepamos, la version del Canciller. La que corre impresa de D. Pedro Nuñez de Delgado se imprimió varias veces en el siglo xvi, y hemos visto ediciones de Sevilla I 502, I 519,1540 y I 552 , Toledo, 15 I2 y 1562 , Medina del Campo 1587 , etc. De presumir es que Nuñez Delgado aprovechase la traduccion del Canciller, como ya lo sospechó Nicolas Antonio; pero la verdad es que en ninguna de las ediciones que hemos consultado, lo declara así. 
el Rey D. Pedro fasta el Rey D. Enrique el Tercero; é hizo un buen libro de caça, ca fué muy grand caçador, é otro libro rimado del Palacio (I), etc. Amó muncho á mugeres, mas que á tan sábio cavallero como á él se convenia. Murió en Calahorra en edad de setenta y cinco años, año de mil é quatrocientos é siete.»

Dedicó el Canciller su libro á D. Gonzalo de Mena, obispo de Búrgos, á quien llama "pariente y amigo», y terminóle, segun la nota final, en el castillo de Oviedes, en Portugal, en Junio de r 386, por haber caido prisionero con la flor de la caballería de Castilla, en la célebre batalla de Aljubarrota.

Su libro de las aves, aunque muy citado de cuantos escritores se han ocupado del arte llamado Acceptreria ó Cetrería, no habia nunca sido impreso. Sale ahora á luz con las circunstancias que dejamos declaradas, habiéndose, segun parece, consultado para su impresion cuatro códices que el editor designa respectivamente con las letras A. B. C. y D. Es el primero y más antiguo de todos el que posee en esta córte el conde de Altamira, en fólio menor y pergamino avitelado, y de letra, al

La cdicion príncipe de la Historia Troyana de Guido de Columna ó de Columnis es de Colonia, ${ }_{477}$; á la vista tenemos una hecha en Argentina (Strasbourg) en 1486 , que no cita Brunet.

(1) Este ha sido publicado por primera vez por D. Florencio Janer, entre los poetas anteriores al siglo xv. tomo xı. de la coleccion de Rivadeneyra. 
parecer, del siglo xv. Otros varios de inferior nota se custodian en la Biblioteca Nacional, en la de la Real Academia de la Historia y en la del Ministerio de Fomento; pero por las causas arriba indicadas, y faltando entre los papeles del Sr. Lafuente la descripcion de los que le sirvieron para el cotejo, no nos ha sido posible fijar con exactitud ni la biblioteca á que pertenecen, ni la signatura que los distingue.

Casi contemporáneo del Canciller fué Johan de Sant Fagund, cazador del rey D. Juan II de Castilla, el cual habiendo obtenido licencia "para ordenar una pequeña regla de cómo se pueden regir y gobernar los falcones, açores é gavilanes, » compuso una dividida en tres libros ó tratados, que presentó al rey Enrique IV, hijo y sucesor de aquel Monarca. No se conserva, que sepamos, el original de dicha obra, pero en la Biblioteca Nacional de esta córte hay copia esmerada hecha á fines del siglo xvi, juntamente con la glosa ó comentario del duque de Alburquerque. Es un tomo en $4 .^{\circ}$ mayor de 230 hojas, y está señalado con la L. 86.

En este tratado, posterior al de Ayala y escrito quizá con mayor claridad y órden, el autor consignó, no sólo las lecciones y avisos de su propia experiencia, sino tambien las reglas y preceptos «que yacian, escriptas en otros libros "), como:

El libro del Rey nuestro Señor (1).

(1) ¿Habrá de entenderse aquí el libro que tiene en su ci- 
El libro del Rey Balarte.

El de Maestre Guillen, fijo de Rojel Napolitano.

El de Hipocras, el philosopho.

El de Anchís.

El de Aramante, fijo del Rey Galisiano.

El de Mohamad, natural de la ciudad de Fez.

El de Menino de Portugal.

El de D. Felipe de Ories, (I) rico-home de Aragon.

El de Pero Lopez de Ayala.

Este libro de Johan de Sant Fagund, comentó y glosó el célebre favorito de Enrique IV, D. Beltran de la Cueva, duque de Alburquerque, conde de

mara, ctc., ó el libro que compuso nuestro Señor el Rey, es decir: D. Juan el segundo? Ambas interpretaciones nos parecen plausibles, tanto más cuanto Fernan Perez de Guzman dijo de él en sus Generaciones y Semblanzas:

"Usó mucho la caça é el monte é entendia bien en toda la arte de ello."

Además del ejemplar arriba descrito y señalado con la L. S6, hay en la Biblioteca Nacional otros dos, y en la de Fomento un tercero, en que están reunidos el Pero Lopez de Ayala y el San Fagund. En ninguno de cllos, sin cmbargo, se encuentran las Glosas del Duque. ¿¿De dónde, pues, las sacó el Sr. Lafuente?

(1) Mossen Felipe de Urries, décimo de este nombre, tercer señor de Ayerbe, llamado el Celludo, que murió en 1453. Trata de él La Tassa en su Biblioteca Antigua de escritores aragoneses en el atículo correspondiente á su nieto Mossen Ugo (tomo 11, pág. 293), aunque sin mencionar el libro de Cetrería que aquí se lc atribuye. Otro caballero de esta familia, que fué mayordomo del Rey de Aragon, y se llamaba Pedro Jordan Durrez (ó de Urries) se halla mencionado á páginas 12 del libro del Canciller. 
Huelma y de Ledesma, el cual, como fuese muy aficionado á la caza de azor, y á todo género de entretenimientos cortesanos, hizo añadir sus propias observaciones á la obra de aquel: «E por ende el muy ilustre Sr. D. Beltran fizo aquí escribir las espirencias que en los falcones de su señoría experimentó, añadiendo y aumentando por glosa en los capítulos del dicho libro de Johan Sant Fagund las dichas espirencias que en adelante se siguen, las quales mandó su señoría á sus caçadores provar, é fallólas ende muy provechosas en sus falcones, é mandó además su señoría sacar en este dicho libro las propiedades de las medicinas.)

Entre los papeles del Sr. Lafuente no ha sido posible hallar indicacion alguna, ni sus más íntimos amigos nos las han podido proporcionar, acerca del códice de donde se sacaron las Glosas del Duque de Alburquerque, impresas á continuacion del libro del Canciller. Verdad es que en la Biblioteca Nacional de esta córte se halla, segun arriba hemos dicho, la obra de Sant Fagund, glosada por D. Beltran de la Cueva; pero dicha glosa está intercalada en el texto, y no por separado, y además cotejada con la presente se ve que es muy distinta. Por otra parte los treinta y tres capítulos impresos concuerdan perfectamente en los epígrafes y en la materia con otros tantos del libro del Canciller, bastando para persuadirse de ello el simple cotejo de su contenido. De manera que las glosas del Duque, que ahora se 
imprimen, no son, como hubiera podido creerse, al Libro de las aves que cacan, compuesto por Johan de Sant Fagund, sino al Libro de las aves de caça, $\dot{e}$ de sus plumages é de sus dolencias é melecinamientos, del canciller Pero Lopez de Ayala.

Natural era que D. Beltran, que tan aficionado se mostró siempre á este género de ejercicio, y tal práctica adquirió en él, comentase y glosase las dos obras principales que sobre cetrería y caza con azor cxistian en su tiempo; pero lo volvemos á repetir, por más diligencias que hemos hecho no nos ha sido posible averiguar qué códice ó copia tuvo presente el difunto bibliófilo para la impresion comenzada y que no tuvo la dicha de ver concluida.

Continuando, pues, la série bibliográfica de obras en este género, asunto de suyo interesante y que no podia menos de entrar en las miras de tan distinguido editor, añadirémos que en la biblioteca de la Real Academia de la Historia se conserva otro tratado de cetreria intitulado: Libro de caza de halco. nes hecho por Alonso Velazquez de Tovar, del cual hay tambien copia en la Nacional, señalada con la L. I 7 . Nada sabemos de su autor que parece haber florecido en la última mitad del siglo xv.

Ximeno Lope\%, de quien solamente se sabe que habitaba en Nápoles y escribia á mediados del siglo xv, compuso otro libro que, aunque falto, se halla tambien en la Nacional con la siguiente nota final: El presente libro fué acabado, Dios sea loa- 
do, en Nápoles, la vispera de Todos Santos, por manos de Ximeno Lopez. Año de mccccxlvi. Es en $4 .^{\circ}$ y copia del siglo xviri. Posible es que no fuese Lopez autor de él, sino simplemente "copiante».

Mossen Johan Valles, tesorero general, y del Consejo del Emperador en el Reino de Navarra, escribió por los años de 1556 un libro de Acetrería, que original se conserva en la ya expresada Biblioteca Nacional. Es un tomo en fólio, con 229 hojas: útiles, y dividido en cinco libros ó tratados, de los cuales los cuatro primeros tratan exclusivamente de la caza con azores ó gavilanes, y el último de montería. Dedicóle al príncipe D. Cárlos, hijo de Felipe II, mancebo á la sazon de once años, y cuyal temprana y misteriosa muerte tanto ha dado que pensar á críticos nacionales y extranjeros.

D. Matías Mercader, arcediano de Valencia, de quien habla largamente Perez Bayer en sus notas á la Biblioteca Vetus de Nicolás Antonio, parece haber compuesto en latin dos tratados de cetrería, que originales se conservan en la Biblioteca del Escorial. Uno de ellos intitulado: Tractatus de re accipitraria, seu de medendis accipitrum morbis, dedicado al rey D. Fernando I de Nápoles en 1465. Se tradujo al castellano bajo el siguiente título:

"Breve trasunto sacado de los originales libros que los señores Reies de Aragon tenian para el conocimiento de las aves de caça y de toda naturaleza de halcones. Con una breve práctica de sitrería 
(sic) para curar las enfermedades y dolencias que acaecen. Compuesto por el muy reverendo y muy ilustre canónigo D. Mathias Mercader, arcediano de la Santa Iglesia Metropolitana de la ciudad de Valencia, á peticion del invictísimo señor D. Fernando de Aragon, Rey de Nápoles, Sicilia y Ungria, y tambien del generoso y virtuoso canónigo Pedro Lopez de Ayala. Dirigido al ilustrisimo y reverendísimo señor obispo de Burgos D. Gonzalo de Mena. Con las anotaciones del emperador Federico II y del Rey Manfredo, su hijo. El cual sirve para el Excelentísimo señor conde de Concentaina, virey y capitan general en este reino de Nápoles.» Un tomo en cuarto de 28 hojas, con las capitales y el frontis rudamente iluminadas, siglo xvir. Bib. del Ministerio de Fonnento.

El ya citado libro de Matías Mercader se tradujo igualmente al italiano por un anónimo que le añadió al fin un recetario para los halcones. Hay copia de él en la Biblioteca Escurialense (I), así como de otro libro, tambien italiano, del cual hemos hallado una breve noticia entre los papeles del Sr. Lafuente, quien sacó de él (2) las tres láminas de halcones

(1) Tomo II, pág. 294.

(2) Es un tomo en fólio menor, escrito en vitela, de letra al parecer del siglo xvı, con sesenta y dos hojas útiles, lujosamente encuadernado en terciopelo azul. Tiene en el fólio $10^{\circ}$ un escudo de armas miniado, y en el $2 .^{\circ}$ un azor, un gavilan y un halcon en sus alcandaras doradas, sus pihuelas y cascabeles, y pen 
con sus correspondientes alcandaras, pihuelas y capirotes, que acompañan á este tomo.

D. Luis Zapata, señor del Cehel, autor de una Miscelánea que anda impresa en el Memorial histórico de la Academia (tomo xi), pero más conocido aún por su Cárlos Famoso, poema épico de escaso mérito literario, en que se recuerdan las hazañas del Emperador ( $\mathrm{I} /$, compuso un libro de cetreria en verso, que se conserva aún inédito $(2)$.

Las expresadas obras y alguna otra más que podriamos citar, se escribieron hasta mediado el siglo xvi, en que por varias causas, y principalmente por la mejora del arcabuz, comenzó á decaer el arte de la Cetrería.

dientes de aquellos los capirotes con los guantes para ilevarlos en el puño. Empieza el texto al fólio $3 .^{\circ}$ con estas palabras: "All "lmo. Príncipe et signore, monsignore Odeto, Conte de Foix et "de Comenge, signore de Lautrech et de Fronsat, Marescalo de "Franza, Gubernatore de Aquitania et Viceregio e loco tenente generale in Italia."

Segun se ve este libro se dedicó á Odet de Foix, señor de Lautrec, quien habiendo seguido á Luis XlI en su expedicion á Italia, se distinguió en la célebre batalla de Ravena en 1512 , de cuyas resultas Francisco I le nombró tres años despues su teniente general en Italia. Entre esta fecha, pues, y la de 1522 , en que derrotado en Bicocca tuvo que pasar los Alpes y refugiarse en Francia, debe fijarse la época de este tomo que, aunque anónimo. tiene todas las apariencias de original.

(1) Imprimióle en Valencia Juan Mey, 1566 , cuarto.

(2) Véase la introduccion á dicho tomo del Memorial Histórico, pág. IX. 
Con todo durante el siglo xí se publicaron en la Península otras dos, castellana la una, portuguesa la otra, ac arca de las cuales nos ha parecido decir algo en este lugar, por ser en el dia muy buscadas y venderse á precios muy subidos. Fué autor de la primera un caballero palentino, emparentado con las familias más ilustres del reino, cuyo nombre era D. Fadrique de Zúniga y Sotomayor, señor de las villas de Alconchel, Çahinos, Mirabel y otras, cuya hija Doña María estuvo casada con el célebre Don Luis de Ávila, historiador de Cárlos V. Fué D. Fadrique uno de los caballeros más honrados en la córte del Emperador, y extremada su aficion á la caza, como él mismo lo declara en el capítulo primero de un libro que compuso intitulado: Libro de cetreria de caça de azor, en el qual por diferente stilo del que tienen los antiguos que están hechos, verán los que á esta caça fueren afficionados, el arte que se ha de tener en el conoscimiento y caça destasayes, y sus curasy remedios, en el cual alli mesmo habla algunas cosas de halcones y de todas aves de rapi ara, y cómo se han de curar y preservar para que no cayan en dolencias. En Salamanca. En casa de Juan de Canoua. Año mplxy. Un tomo en cuarto de 126 hojas, señaladas con números romanos y además otras seis de preliminares y tabla.

Está dividida la obra en dos libros, de los cuales el primero habla de las diferencias de azores, gavilanes, halcones y otras aves de que el hombre se 
servia para la caza llamada de volatería ó altanería y la manera de educarlos y gobernarlos. Trata el segundo de las enfermedades á que dichas aves están sujetas y el medio de conocerlas y remediarlas.

Fué D. Fadrique aticionado en extremo á dicho noble ejercicio como él mismo lo declara en algunos pasajes de su libro, y sobre todo en el prólogo ( I), donde dice: "Y aunque yo en unos y en otros ejercicios pudiese tener parte, soy más inclinado desde mi niñez al ejercicio de la caza, así porque he empleado los más y mejores años de mi vida en él, como porque gastando las horas en este pasatiempo, olvido otros muchos cuidados que me dan pena, y puedo dejar sin perjuicio de mi honra, y aun porque la vida del campo tomada en sazon me es más alegre y saludable que la del pueblo, y así andando á caça, ora sea por el ejercicio que hago ó por alegría con que la ejercito, ó por la limpieza ó pureza de los aires del campo, me siento más libre de males y enfermedades que cuando estoy muchos dias en el pueblo, y entre las otras cosas que los ingenios de los hombres han hallado, yo soy más dado á la caça de açor, no porque no guste de las otras, ni las deje de usar, sino porque tengo más horas empleadas en esta y me he dado más á ella,á causa de ser la tierra de esta ciudad de Plasencia (donde

(1) Véase el capítulo primero que sirve como de introduccion ó prólogo á toda la obra. 
he vivido y vivo) más aparejada para la caça de açor que de halcon, por el aspereza y sierras de ella; y aun digo que para el ejercicio de la guerra no está mal al caballero que sea caçador desta caça, porque aunque en todas se ejercita el hombre, paresce que en esta se desenvuelve más en la silla, así por andar y correr en tierras más fraguosas, como por hacer más lance con el açor que con los halcones. Así que entre los otros ejercicios á que yo tengo inclinacion, éste de la caça con açores, me es más agradable y le tengo más usado. Y quiero así por esta causa, como porque los caçadores antiguos que escribieron de cetrería hablaron generalmente sobre todas las aves de rapiña, hacer una breve summa que trata principalmente de açores y gavilanes, de que se aprovechan los noveles caçadores que son açor y gavilan, etc.»

Otro tratado notable de este mismo siglo, aunque impreso en el décimo sexto es el de Ferreira, mozo de Cámara del Rey D. Felipe III en Portugal. Es su título: Arte de Caça de Altaneria, dirigida á D. Francisco de Mello, marqués de Ferreira, etc. Composta por Dioguo Fernandez 'Ferreira, moço da Camara del Rey, etc. do seu seruicio. En Lisboa. Na officina de Jorge Rodriguez. Anno de MDCXvi, cuartode i I hojas foliadas, 5 de preliminares $y$ tres más al fin sin foliar.

$\mathrm{El}$ autor fué page de D. Antonio, prior de Ocrato, y criado en su casa desde la más tierna edad. 
Debió nacer por los años de 1546 , puesto que en 1616 , cuando se imprimió su obra, contaba ya setenta años de edad ( I ). Es esta considerada clásica por los portugueses, y está dividida en seis partes: r. " De los gavilanes. 2. De los azores. 3. ${ }^{a}$ De los halcones. 4. ${ }^{a}$ De las dolencias y sus medicinas.

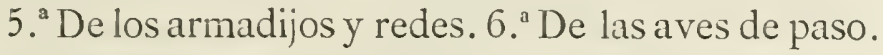

Está la obra precedida de una advertencia en declaracion de los vocablos oscuros, y salpicada de anécdotas que hacen su lectura sabrosa y entretenida en extremo. Cita el autor muchos caballeros portugueses aficionados á la cetrería, y entre ellos al conde de Tentugal, á Alfonso Borges, criado del rey D. Sebastian, á Vicente Queimado, D. Juan Mascarenhas, D. Antonio, prior de Crato (Ocrato) y otros. Erale conocido el libro del Canciller, del que hace citas frecuentes, y su obra toda está trabajada con esmero, aunque pésimamente impresa, como ya lo advirtió Innocencio Francisco da Silva en su Diccionario Bibliográphico portugués.

Concluido ya el cuadro bibliográfico que nos hemos propuesto trazar, queda aún otro punto, acerca del cual nos cumple hacer una advertencia preliminar. Nuestros lectores habrán reparado que, exceptuando las breves notas al pié de cada página,

(1) "Pello que (dice el autor en su prólogo) ñao perdoei ao trabalho sendo de setenta annos de tirar á luz esta scienzia por ime criar nella desde minha mininese caçando con Assores, Falcóes, Gaviaes, etc. Esmerilháes.” 
para señalar alguna que otra variante de escasa importancia, ni la obra del insigne Canciller ni las Glosas del duque de Alburquerque están ilustradas con aquel esmero y laboriosidad que eran de esperar de un escritor tan distinguido como el Sr. Lafuente. Sobre haber en dichas dos obras algunas frases y vocablos de dudosa inteligencia, son muchas las alusiones que en una y otra se hacen á personajes históricos aficionados á la cetrería, y varios los pasajes que sin la conveniente declaracion podrian quedar oscuros. Habia además correcciones, y quizá tambien adiciones que hacer al texto, habiendo todo quedado en suspenso por la temprana y sentida muerte del editor, quien se propondria dar cumplida cuenta de todo en una introduccion. Comprometidos, pues, en cuanto nos era posible á llenar dichos vacíos y omisiones, hemos formado un índice de los nombres propios ó geográficos que ocurren en ambas obras, y salvado al fin del tomo las erratas que en su lectura hemos notado, considerándonos dichosos si la obra por este medio se presenta al público digna de la Sociedad de Bibliófilos que la mandó imprimir, y del erudito cuanto laborioso jóven que la tomó á su caryo. 
CLTRERIA

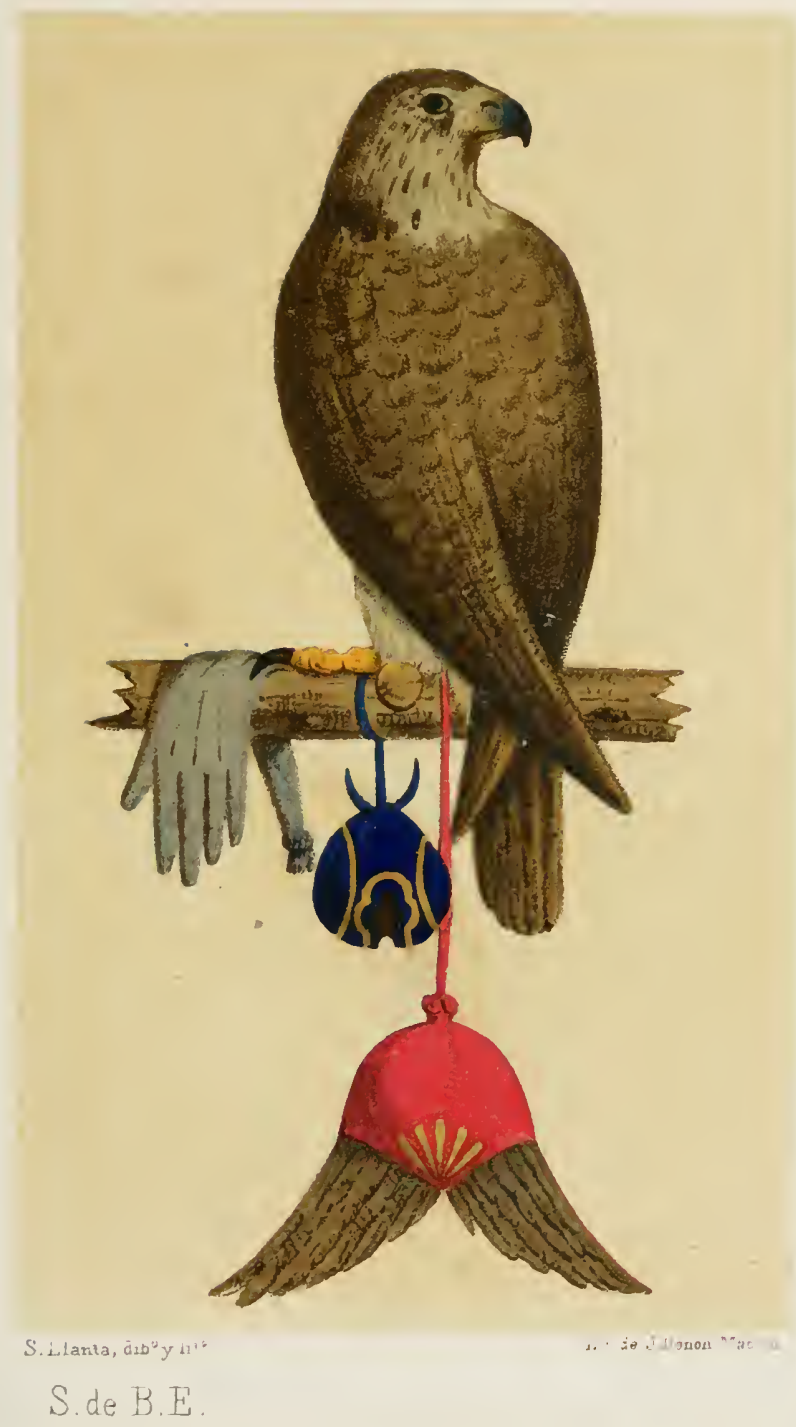



CETRERIA.

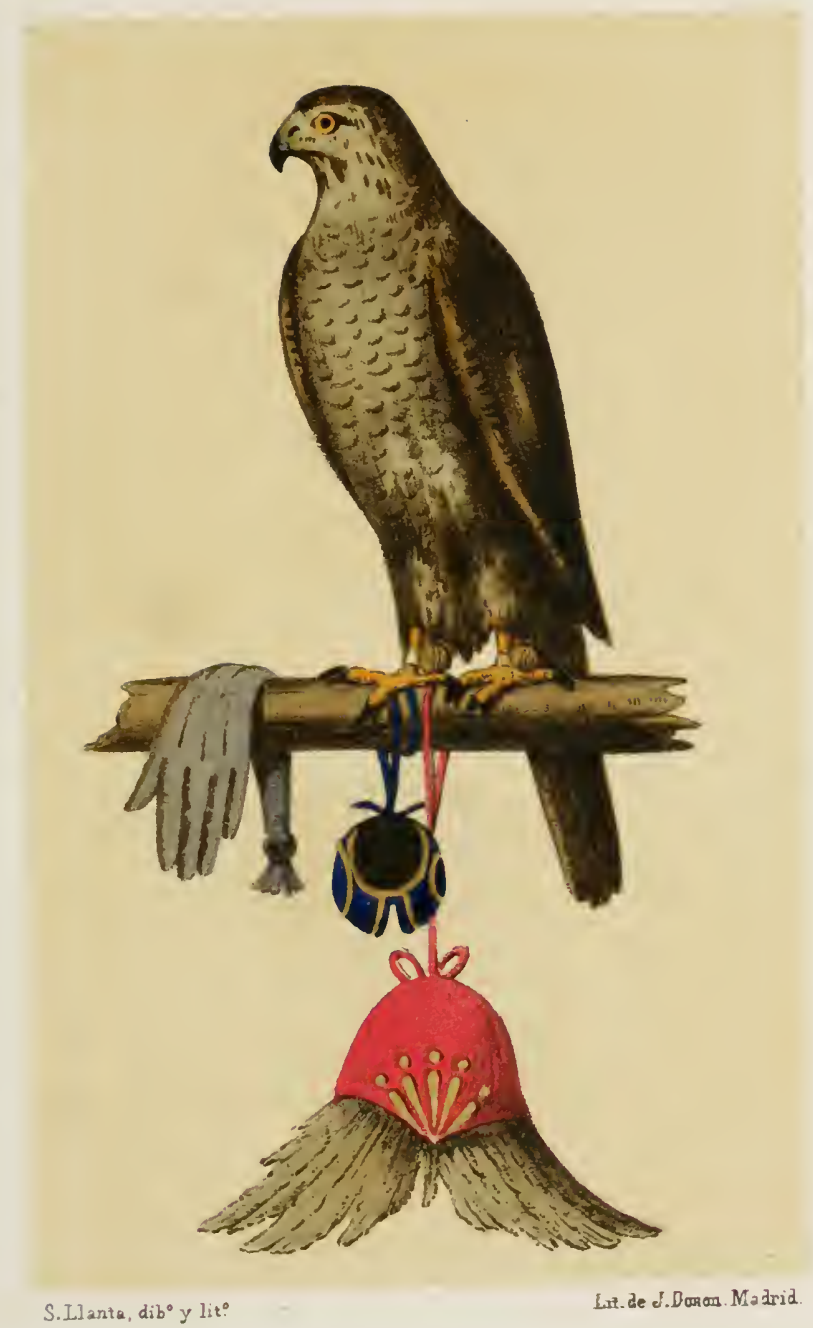

S. de B.E. 



\section{CETRERIA.}

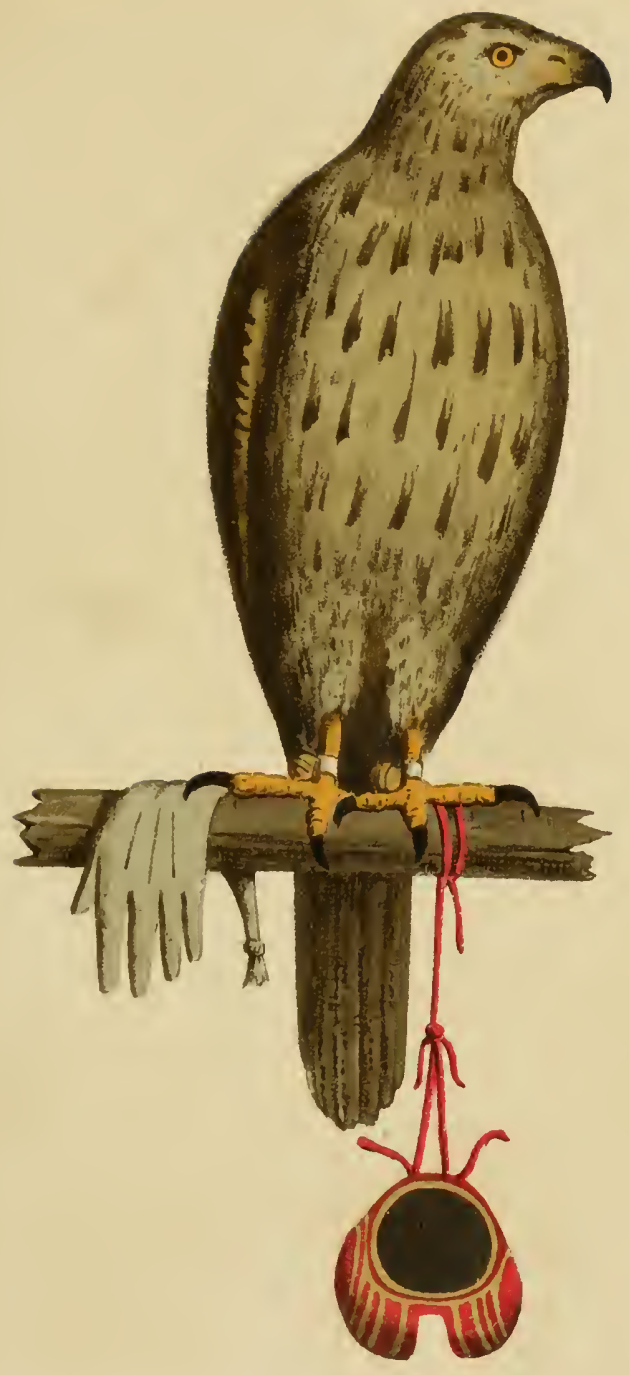

S. de B.E. 



\section{CRISTUS ADSIT NOBIS GRATIA}

EN EL NONBRE DEL PADRE ET DEL FIIO et del espiritu sancto amen. Dize et amonéstanos el apóstol que todas las cosas que auemos de fajer fagamos en el nonbre del señor, porque todo don bueno é acabado dél viene, et sin él non puede ser fecha cosa alguna. Et por ende, llamando la su ajuda et gracia, començaré nna pequeña obra para exercicio de los ombres, por los tirar de oçio et pensamientos, et puedan auer entre los sus enojos et cuydados algund plajer et recreamiento sin pecado; la qual obra será un pequeño escripto, en que departira de la caça de las aues et de sus plumajes et dolençias et melezinamientos.

Al muy honrrado padre é señor don Gonçalo de Mena I, por la gracia de Dios obispo de la muy noble çibdat de burgos, Pero Lopes de ayala, vuestro homil pariente et seruidor, me encomiendo en la vuestra merced. Señor, dize el filósofo Aristó

1 B. Miena. C. Niebla. 
teles en el otauo libro de las éticas en la filosofia moral, que á los verdaderos amigos de buena et honesta amistança 1 non los departe la distançia de lugares; que quiere dezir que por estar los omes 2 amigos verdaderos alongados uno de otro é arredrados por luenga tierra, la verdadera é honesta amistança non se departe de entre ellos, antes está et dura firme en su virtud. E señor, gran tiempo há que fuy et só alongado de vuestra presençia é vista por luengo apartamiento de tierra, empero sienpre la ruestra buena et verdadera et onesta amistança touo siempre en $\mathrm{mí}^{3}$ toda su virtud. E señor, como en las quexas et cuydados sea grand consolaçion al paziente auer memoria de sus amigos, por ende, señor, en la mi grand cuyta é quexa que tomé de tiempo acá en la prision dó estó, oue por consolaçion acordarme de la vuestra verdadera amistança. Ca, segund dize sant exidro, cuando el ome está en buen estado et seguro, la verdadera amistança faze las cosas más dulçes que son. Et si el amigo está en tribulaçion, la buena et verdadera amistança pone en las cosas contrarias y tristes consolacion et grand aliuiamiento. Ca con la consolaçion del amigo sostiénese el corazon del tribulado, et non puede caer 4. Et como por muchas

1 B. Et leal amistad.

Falta en B. Ones.

3 B. Todo siempre en mi touo.

* B. falta caer. 
vegadas fuy alegre et consolado de vos en la caça de las aues, así como de aquel que toue sienpre en ella por maestro et señor ; et por quanto, señor, en esta arte et çiençia de la caça de las aues oy et vi ${ }^{1}$ muchas dubdas, así en el departir de los plumajes et condiciones et naturas de las aues, otrosí en las fazer et ordenar para tomar aquellas presiones que deuen; otrosí para las melezinar cuando adoleçen et son feridas, et desto vi algunos escriptos que departian desto, pero non concordauan unos con otros; Otrosí vi muchos caçadores departir desto ${ }^{2}$, et cada uno tenia su opinion, et por esto acordé de trabajar por non estar oçioso ${ }^{3}$ de poner en este pequeño libro todo aquello que más cierto fallé, así por los libros como por las opiniones de los caçadores, segund la espirençia que deste fecho proué et vi. Et fecho este pequeño libro, acordé de vos lo enbiar, así como á mi señor et á mi maestro, para que lo vos veades, et emendedes et anyadades et mengüedes lo que á la vuestra merced ploguiere. Ca en aquella opinion que vos quisierdes et determinardes, en aquella me acuerdo. Et en este libro tomaré esta órden : primeramente mostraré cual fué la razon que mouió á los omes á la caça de las aues; Et despues porné
B. hoy vi.
B. En esto.
3 C. no estar en esto ocioso. 
capítulos ciertos de todo I lo que aprendy et vi et oy en esta arte, así de los plumajes, como naturas et condiçiones de las aues; et dende la plática del falcon neblí, porque es más noble, et más gentil de todos. Otrosí dende porné las dolençias et señales dellas et melezinamientos et rremedios para ellas.

Nuestro señor Dios quando crió el mundo et fizo ome, todas las animalias por él criadas fizo et puso para seer al seruicio del ome, 2 Et por ende dixo el propheta dauid en el psalmista, alabando á Dios de las gracias et mercedes señaladas que fizo al ome: "todas las obras señor por tí fechas sujugaste al seruicio del ome, aues del cielo, etc.»

Et porque los seruicios que el ome ha de tomar de las cosas, deuen ser onestos et con razon 3 , et por esto acordaron sienpre todos los sabidores que los omes deuen escusarse mucho de estar oçiosos, ca es causa et achaque de pecar; ca non se ocupando el ome en algunas cosas buenas et onestas, naçel ende pensamiento en el corazon del qual pensamiento naçe tristura et amortificamiento; et de la tal tristura viene escándalo et desesperamiento, que es rayz de todo perdimiento. Et otrosí, así como el oçio, segund dicho auemos, traye estos dapnos et males al alma, así trae grand

I B. porné por capítulos ciertos todo lo que aprendí \&.

2 D. para el su seruicio.

3 D. E porque los seruicios del hombre han de ser siempre y tomar de las cosas honestas et razonables. 
dapno al cuerpo, que quando el ome está oçioso sin fazer exercicio, et trabajar con el cuerpo et mudar el ayre, fatíganse los humores et al cuerpo dende le recrecen dolençias et enfermedades. Et por escusar estos dapnos ${ }^{1}$ que vienen al ánima et al cuerpo en estar los omes oçiosos, fallaron aquellos que ouieron de criar los fiios de los reyes et de los príncipes et grandes señores, que los touiesen á todo su poder guardados de ser oçiosos, et trabajasen et fiziesen exerçiçio por sus personas et cuerpos 2 en algunas cosas buenas et honestas, con que tomasen plazer sin pecado, siruiéndose et aprouechándose ${ }^{3}$ de las cosas que Dios crió et fizo para seruicio del ome, segun dicho es. Et entre las + muchas maneras que cataron et fallaron para esto, vieron otrosí que era bien que los señores et príncipes anduviesen algunas oras del dia, como en la mañana et en las tardes, por los canpos, et mudasen el ayre, et feziesen con sus cuerpos exerçiçio. Et pues que así andauan, que era bien que ouiese omes sabidores en tal arte, que sopiesen tomar de las aues brauas, et las asegurasen et amansasen, et las fiziesen amigas et familiares del ome. Et despues con las tales aues tomasen de las otras aues que andauan brauas, et esquiuas por el
B. estos dos daños.
A. Omite personas.
B. D. sirviendo et aprouechándose.
B. D. Omiten las. 
ayre. Et que los tales maestros para fazer esto fuesen muy sotiles et muy ciertos en la tal arte, que asaz I es sotileza et marauilla que por arte es sabiduria del ome una aue tome á otras de las que por su naturaleza nunca tomara, nin en aquella manera que gela fazen tomar; así como un falcon tagarote veemos que por su arte et sabiduria del ome 2 toma una grua, que es aue tan grande et tan layda; otrosí derriba el cisne et el abutarda et la çigüeña et la ansar braua, et enbárgalas en tal manera, que un galgo traua dellas et las tiene fasta quel caçador llega et las toma. Et otrosí en la caça de las aues ay otros bienes, que es una virtud que llama el filósofo en el quarto libro de las éticas manifiçençia, que quiere dezir grandeza ó fechos de grandes señores; ca noble cosa es et grandeza á un seĩor tener falcones et açores et aues de caça en su casa, ca quien los tiene como deue, paresçen muy bien las tales aues en las casas de los grandes señores; otrosí en el canpo delante de ellos quando caualgan et van á uer tal caça. Et por ende trabajaron de auer ${ }^{3}$ la tal caça de aues; et pues que della es la presente materia deste libro, porné aquí los capítulos por los quales podran saber aquellos que desta arte tomaren plazer algunas cosas prouechosas para ayuda de la dicha arte.

\footnotetext{
1 B. D. é asaz.

2 B. y D. Omiten delome.

3 B. trabajaron de uer.
} 
Cipítulo 1. De las aues que son llamadas de rapiña así como açores, falcones et gauilanes, esmerejones et alcotanes.

Capítulo ir. De los 1 plumajes de los falcones 2, et primeramente del falcon neblí.

Capítulo iiı. Del falcon baharí et tagarote.

Capítulo ini. Del falcon girifalte.

C.tpítulo v. Del falcon sacre.

C.Aṕ́tulo vi. Del falcon borny.

Capítulo vir. Del falcon alfaneque.

C.spítulo viri. Como se deue regir et gobernar el falcon neblí é ciertas reglas de platicas para ello ${ }^{3}$.

Capítulo ix. Como se deue alinpiar el falcon del piojo.

Capítulo $\mathrm{x}$. Como se deue purgar el falcon del agua comun que no es vidriada.

Capítulo xi. Como se deue purgar el falcon del agua vedriada. Capítulo xir. De la purga comun para purgar el falcon del cuerpo.

Capítulo xir. Del falcon que deseca.

Capítulo ximr. Del falcon que es asonbrado.

Capítulo xv. Del falcon que ha güermezes 4.

Capítulo xir. Del falcon quel remaneçe el papo 5.

Capítulo xvir. Del falcon que tiene el papo é tripas 6 llenas de viento.

Capítulo xviri. Del falcon que tiene plumas 7 viejas.

CApítulo xix. Del falcon que ha finchamiento en el buche.

C.

Capítulo xxi. Del falcon que ha filandras 8 , ó filomeras.

Capítulo xxir. Del falcon que tiene piedra.

Capítulo xxirr. Dela fistula que se faze en la plaga del falcon.

I B.y D. Que fabla de los y asi en lo sucesivo.

2 B. De las aues.

3 B. y D. Que fabla en que manera se deue regir el falcon nebli, et de ciertas reglas para él.

4 R. y D. Que fabla de los güermezes que son engendradosen la cabeça del falcon.

5 B. y D. Que remanecen con papo.

6 A. omite é tripas. C. la gorga llena de viento.

7 B. y D. Plumadas.

8 B. Filandres. 
Capíturo xxin. De la comezon que tiene el falcon en las plumas que se las come et se las tira ${ }^{1 .}$

Capírulo xxy. Cuando se le tira ó cae al falcon la unna.

Capítulo xxvi. Del falcon que há clauos en los pies.

Capítulo xxvir. Del falcon que ha finchados los pies, ó le arden 2.

Capítulo xxvill. Del falcon que se le quiebra la pierna.

Capítulo xix. Del falcon que se le quiebra el ala.

Capítulo xxx. Del falcon que se le quiebra el ojo.

Capítulo xxxi. Del falcon que ha finchazon entre el cuero et la carne 3.

Capítulo xxxin. Del falcon que regita et tiene papo et tripas frias.

Capítulo xxxin. De los falcones que son feridos de anes t.

Capítulo xxxini. De la ferida del falcon así abierta como cerrada.

Capítulo xxxy. De la caida, o de la abatidura del falcon en que se él fiere 5 .

Capítulo xxxyt. Del falcon que tiene las tripas fuera.

Capítulo xxxyir. Del falcon que tiene las quixadas torcidas.

Capítulo xxxvin. Como deues fazer la muda á tu falcon.

Capítulo xxxix. De algunos falcones que non quieren mudar et como farás para que tu falcon mude muy ayna.

Capítulo xl. Como farás despues que tu falcon fuere mudado.

Capítulo xh. De los açores.

Capítulo xli. De los gauilanes.

Capítulo xlih. De los esmerejones.

Capítulo xlini. De los alcotanes.

Capítulo xly. Del paso de las aues.

Capítulo xlyı. De como se deuen enxerir las peñolas quebradas.

Capítulo xlvil. De cuales cosas et melezinas deue andar aperçebido el caçador et traer consiguo para sus aues.

I D. De la começon que se face en las peñolas.

2 B. y Is. Omiten o le arden.

3 B. y D. Que han trópigo o finchamiento en el buche o en el vientre.

4 A. Que ha trópigo et finchaçon.

5 B. y D. No tienen este capitulo, y luego hacen del 46 dos distintos. 


\section{CAPITULO PRIMERO.}

DE las aUes que son llamadas de rapiña, así COMO AÇOREs, FALCONES, ET GAUILANES, ESMEREJONES ET ALCOTANES.

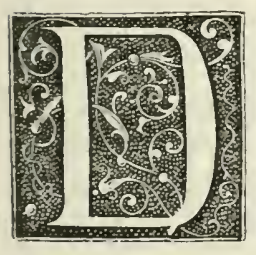

E cada dia vieron los omes de como naturalmente unas aues toman á otras, et se çeuan et gouiernan dellas; et las tales aues son llamadas aues de rapiña; así como son águilas, açores, falcones, gauilanes, esmerejones, alcotanes é otras. Et estas dichas aues, saluo el águila, nunca comen otra carne sinon fuere de aues que ellas por sí toman, et caçan; pero el águila quando non puede tomar ó caçar algund aue de las que acostunbra tomar ó caçar, torna á tomar liebre, ó conejo, ó cordero pequeño, et avn viene al perro muerto, por la grand tragonia que en ella ay. Et otrosí ay otras aues que algunas vezes se çeuan de las aues que toman, pero comunmente sus viandas son carniças de bestias muertas, así como son los cueruos carniceros, que muchas vezes toman aues biuas; pero su caça 
naturalmente es carniça de bestias muertas, et de aquello han su mantenimiento. Et otrosí ay otras aues que son contadas entre las aues de rrapiña, et toman et cacan aues biuas, et eso mesmo toman et se çeuan de ratones et de tales cosas que se crian en la tierra, et destas son atahormas, et budalones et aguilochos. Et todas las aues de rapiña son mayores las fenbras que los machos. Et otrosí ay otras aues que su mantenimiento solo es de carniças, et no toman aues biuas, así como son buetres, auantos, quebrantahuesos. Otrosí ay otras aues que su mantenimiento es de carniças, et gusanos de la tierra, et frutas I así como son cornejas, picaças et otras. Et otrosí ay otras aues que su mantenimiento es de semientes, así como son abutardas, gruas, perdizes, palomas, tórtolas, páxaros 2. Et otrosí ay otras aues que su mantenimiento es de pescados, así como águila pescadora et alcatrazes, et otras aues de mar. Et otrosí ay otras aues que andan ribera de las aguas et su mantenimiento es peçes menudos et gusanos de los que se crian en el agua; et pasçen fuera en las yeruas, así como son anades, cisnes, ansares brauas, et otras. Et así ay aues de muchas maneras et diuersas et de diuersos gouernamientos, pero de todas las aues las más limpias son aquellas que solamente se pascen 3 et mantienen de aues bicas, et cada rez que se quiere çeuar toma aue biua, et desque della son çeuadas non curan de lo que finca, et aunque otro dia lo fallen non curan dello, salio buscar et cazar otra aue biua para su comer. Et estos son açores et falcones, gauilanes, esmerejones, alcotanes : et de tales
D. Omite frutas.
D. Omite paxaros.
A. Omiten pascen. 
aues como estas touieron por bien aquellos que esta arte fallaron de las tomar et de las amansar, et fazer conosçidas al ome, et tomar con ellas de las otras aues brauas, et non solamente tomar con ellas aquellas aues et presiones en aquella manera que la natura les otorga de tomar, mas con el trabajo et sotileza del caçador tómanse otras aues et presiones, et por más estrañas guisas que las soljan tomar. Asi como el falcon tomar la garza alta en las nuues perdida de vista, otrosí tomar la grua yendo alta por el ayre, et así otras aues en muy estraña manera, lo que nunca tomaran sinon fuese por la maestria et sotileza del caçador. Et por esta razon los señores et los que tomaron plazer en tal caça buscaron omes maestros et sabidores et de buen tiento, et de grand sufrimiento para ordenar, et guardar, et caçar con las tales aues. Ca puesto que los señores et los que esta tal caça ploguiese tomasen grand plazer de auer tales aues, et las cobrasen, et las podiesen auer, fincáuales saberlas regir. Otrosí puesto que las ouiesen, como dicho auemos et las sopiesen regir et gouernar fincáuales saberlas guaresçer et melezinar quando adolezcen, et son feridas, et por esto dizia don iohan fiio del infante don manuel, et señor de Villena, que fué muy grant señor, et era muy caçador et muy sotil en esta ciencia de las aues, que grant diferencia auia de querer caçar, et seer sabidor dello en las regir, et fazer las aues; et otrosí auia grant diferencia de saber fazer una aue, á la saber guarescer, et seer buen acetrero, que quiere dezir buen físico para ellas, et buen cerujano. Et porque estas très cosas: primeramente querer caçar et auer grant voluntad dello; lo segundo saberlo fazer et ordenar que tomasen tan estrañas aues, et por tan estraña manera como dicho auemos; lo tercero, cuando su aue adoles- 
ciese, ó fuese ferida, saberla guarescer; et todas estas tres cosas son menester al buen caçador, fablaron los que esta caça plogo en muchas maneras en ello, et fizieron algunos libros, cada uno segund se le entendió et alcanzó su esperiencia. Et como dixe en el comienço, porque auia diuersas opiniones entre los caçadores, acordé de ayuntar en este libro todo aquello que oy á grandes señores et muy caçadores, que más cierto auian fallado, et púselo aquí, so enmienda de los que más y entendieren, lo que yo oy á grandes señores et caçadores en muchas partidas; otrosí oy lo que dixieron algunos dellos que no vy yo. Primeramente en francia al duque de bergonia, et conde de flandes et de artoys, et al conde de tangrabilla; et en aragon al vizconde d'ylla, et á don pedro jordan durrez, mayordomo mayor del rey de aragon, et á don pedro ferrandez de yxar, rico ome. Et en castilla, lo que dixo don juan, fiio del infante don manuel, señor de villena; et á don gonzalo de mena, obispo de burgos, et á don enrrique enrriquez, et á don johan alfonso de guzman, et á remir lorenço, comendador de calatraua, et á garci alfonso de la vega, cauallero de toledo, et á johan martinez de villazan, alguacil mayor del rey, et á don ferrand gomez de albornoz, comendador de montaluan; et lo que dixieron dos falconeros, el uno del rey don fernando de portogal, que dizen pero meniño, et el otro juan ferrandez burriello, falconero del rey don pedro; ca todos estos sopieron et saben mucho en esta arte, et ficieron muchas curas en las aues, que son muy çiertas et muy prouadas. Et luego primeramente diré de los plumajes de los falcones, et quantas maneras de plumajes hay en ellos, et otrosí do crian et nasçen, et que façiones et plumas deuen auer, et despues diré como se deuen mele- 
I 3

zinar quando adolescen, ó son feridos de gruas, ó de garças, ó en otra manera qualquier. Et trabajaré más en la plática del falcon neblí et en su regimiento, ca en verdat este es el más noble et mejor de todas las aues de caça, et quien buen tiento tomare con el neblí, en todas la otras aues podrá tomar buen tiento. 


\section{CAPITULO II.}

LE LOS PLUMAJES DE LOS FALCONES, ET PRIMERAMFNTE I)EL FALCON NEBLI.

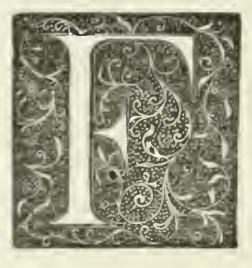

ALCONES entre los caçadores comunmente son llamados seys piumajes, ó seys linajes de ellos, que es á saber: neblís, baharís, girifaltes, sacres, bornís, alfaneques. De los tagarotes non facen mençion aparte, porque son acordados por baharís, que como quier que en el plumaje aya diferençia del baharí sardo, ó mallorquin, ó de romania, con el baharí tagarote; pero en todas las condiçiones son de una naturaleza, segund más complidamente diré adelante en el capítulo que fabla del falcon baharí. Et deuedes saber que en todas las tierras de cristianos, saluo en España, son llamados estos seys plumajes por sus nonbres, ca el girifalte llaman así por su nonbre girifalte, mas non falcon, et al sacre dizen sacre, et alborní et al alfaneque llámanlos laneros. Et á estos todos 
non los llaman falcones, antes dizen que son villanos, así como quien dize falcones bastardos, ó fornezinos, et solamente al nebly, et al bahary llaman falcones et gentiles, ca han las manos grandes, et los dedos delgados, et en sus talles son más gentiles, que han las cabezas más firmes et más pequeñas, et las alas en las puntas mejor sacadas, et las colas más cortas, et más derribados en las espaldas, et más aperçebidos, et más ardidos, et de mayor esfuerzo; et en sus gouernamientos son más delicados que los otros que dicho auemos. Et quieren ser gouernados de mejores viandas, et seer sienpre traydos muy bien en la mano por el grand orgullo que han; et no sosiegan mucho en la alcándara, et son de muy grand corazon. Et los girifaltes et sacres et bornís, et alfaneques son de otros talles et façiones en los cuerpos, et las colas más luengas, et las cabeças grandes, et las manos más gruesas, et los dedos más cortos, et más gruesos, et sufren mejor aun que les den et gouiernen de más gruesas viandas, como quier que de qualquier plumaje que sea el aue, si le dieren buena vianda, et sea bien traydo, siempre lo fallarás en el su bolar, et caçar, et en estar más sano. Pero unos falcones hay que mejor se paran á sofrir en sus gouernamientos de más gruesa vianda que otros, ca si tú dieses la vianda con que el borny et el sacre se gouiernan al nebly, poco tiempo te seruirias dél, ca de su natura es tan delicado, que luego se cargaria de dolençia et se perderia. Et los falcones neblís en todas las tierras son llamados gentiles, que quiere dezir fiios dalgo, et en castilla et en portugal son llamados neblís, pero al comienço fueron llamados nebís, et por tienpo corronpióse este vocablo, et dizenlos neblís. Et en aragon et en catalueña llamanlos pelegrines, por comparacion de los peregrinos et Romeros que 
andan por todas las tierras, et por todo el mundo, que así son los falcones gentiles, ó neblís, ó peregrinos, que todo el mundo andan, et trauiesan con el su bolar, partiendo de la tierra donde naçicron. Pero en francia et en alemania, et Italia llaman falcones pelegrines á unos falcones neblís, que algunas veces son fallados et tomados, que han ya las tixeras más luengas, quanto que los cuchillos mayores, et pasan dellos, lo que comunalmente no han los falcones; et quando tales falcones pelegrines son tomados, préçianlos mucho, ca salen muy buenos. Et deuedes saber que los falcones neblís crian et naçen en la alta alemania, en una comarca que es llamada Asuega; otrosí en noruega et en pruça, et de ally los conpran los mercadores, et los traen en las contres de alemaña, quando vienen en frandes, et tráenlos á brujas, et de ally los lieuan por todas las tierras, á Paris et en bretaña, et en henaut, et inglaterra, et dellos traen en españa á los reyes et á los señores que lo encomiendan á los mercadores, quando allá van á brujas, et gelos traen. Et estos falcones así traydos de los mercadores son muy peligrosos de tomar, ca vienen cargados de agua, et de malos humores, por el gouierno de las malas viandas que les han dado, et por no fazer los mercadores grand despensa et costa con ellos, danles carne de vaca et de oueja. Et comunalmente los más les dan perros, et aun dizen aquellos que los tienen que la vianda más liuiana que fallan para cllos que es la carne del perro; pero estos falcones así governados, como dicho es, son en grand peligro, ca desque los toman los señores et caçadores que los conpran, et los tornan á las buenas viandas, mueren muchos dellos de las filandras, ó filomeras, et del agua vedriada, et dellos que desecan. Et esto es porque con la buena vianda que despues comen muéuense los humores 
malos de que auian cargado con las malas viandas, et vienen á resoluérseles en dolençias mortales. Otrosí los tales falcones de que dicho auemos, son duros falcones de fazer, por quanto son tomados muy cerca de donde criaron et naçieron, et aun algunos dellos en los nidos, et no saben mucho del caçar, porque muy poco tienpo se çeuaron por sí; pero los que escapan, et son fechos, salen muy buenos et muy seguros. Otrosí, ay falcones neblís, que crian en el condado de saboya, en las montañas que son et parten el dicho condado de saboya, et la tierra del señor de mylana, et estos tómanlos en los nidos et no salen tan buenos; et quando los tienen los mercadores para vender entre los otros falcones suyos, luego los conoscerá ome, que así como muestran la claridat para que ome vea los falcones do estan en sus alcándaras, luego los falcones tomados de los nidos gritan et dan bozes, et espelúzanse, et alçan las alas, et paresçen et muestran su pequeño esfuerço. Otrosí muchos falcones neblís se toman brauos por muchas partidas del mundo, et en muchos regnos, et vienen de la tierra et comarca donde crian et nasçen, et vienen con el paso de las aues, así como con sisones, et palomas, et otras aues de paso. Et estos falcones así uenidos, los unos se toman muy tenpranos, como en el mes de setienbre et octubre et nouienbre et dezienbre; ct los que se toman dende adelante fasta comienço de febrero son más tardios para façer, et llámanlos en francia á estos falcones tardíos así tomados, falcones de rapela, et salen muy buenos, ca saben ya mucho del caçar, et traen todo el plumaje deslanado de las aguas, que ha grand tienpo que duermen fuera. Et traen la cola toda roçada en las puntas de las péñolas, del estribar que fazen sobre ella, quando toman las presas et se çeuan en el canpo, et préçianlos mucho los caçadores, 
porque tales falcones como estos non ay en ellos otro trabajo sinon fazerlos seguros et señoleros, que quanto el caçar, ellos lo saben ya. Et á los falcones primeros, que deximos que eran tomados tan tenpranos, llaman en francia falcones presos sobre el pays, et en castilla á todos los falcones así tomados de qualquier plumaje que sean llaman falcones çahareños ó arávigos. Et quanto en castilla, los mejores neblís que se toman son los de las rocinas, et en tierra de Seuilla, et otrosí son muy buenos en portogal los que se toman en el canpo de santaren, et todos estos falcones salen muy buenos, ca se toman muy lexos de la tierra donde nasçen, ca segund todos cuydan, ellos vienen de nuruega et pruça et asuega et de cabo de la alta alemania, do criaron et nasçieron, et venieron con el paso de las aues, ca en españa no fué ome que fallase nido de falcon neblí. Otrosí son muy buenos estos falcones así tomados en las roçinas et cerca de las marismas, por quanto de cada dia se çeuan de aues de ribera, así como en abocastas et anades et garçotas et otras que son raleas buenas, pero que el falcon neblí de su naturaleza ha de tomar á ellas. Otros falcones neblís se toman en castilla en los pinares de olmedo, et de aquellas comarcas, et estos non salen tan ciertos ni tan seguros como los que decimos que se toman en las rrocinas, ca estos falcones tomados en los pinares son más bulliçiosos, ca sienpre se ceuan en palomas et cornejas et sisones, que son raleas peligrosas, lo uno porque ay muchas dellas, et otrosí porque el falcon se va muy longe á perder con ella, et si alcança, céuase, et piérdelo muy ayna el caçador. Otrosí en muchos regnos et partidas se toman falcones neblís brauos, et los de la una comarca salen mejores que los de las otras. Pero tan noble es el falcon nebli, et de tan buen esfuerço, que si con él trabaja- 
res, sienpre fará bien, como quier quel plumaje bueno, et ser tomado en buena comarca, et en buen tienpo, et buena mano de caçador, et grand sofrimiento, et buena vianda, mucho emienda el nebly, et el contrario desto non ay dubda que dapna. Et deuedes saber quel falcon pocas rezes acaesçe al ome de escojer en ellos, ca non ay en esta tierra tantos, et quando ome lo cobra toma lo que falla; pero si acaesçiere que lo ayades de escojer, así como en los lugares que los mercaderos los tienen ayuntados para render, ó si los rederos que los toman acaesce á las rezes tener dos ó tres de ellos, deues saber conoscer sus plumajes, porque tomes de lo mejor. Falcones ay neblís que han lo blanco mucho et muy blanco, et lo al como gris, et son estos falcones llamados en francia falcones de dames, quiere dezir falcones de dueñas, et son muy fermosos et muy dulces de fazer, et de muy buen talante, et han el plumaje muy bueno et non tan brozno como los otros plumajes, et avn han las colas más luengas et salen buenos garçeros. Et á tales falcones de tal plumaje suelen en castilla llamar los falconeros et caçadores, donzellas; et en francia llámanlos blanchantes. Otros falcones neblís ay que es su plumaje ruuio, et la punta gruesa, et son de grandes cuerpos et salen muy buenos altaneros et garceros. Otros falcones hay que sus plumajes son pardos et la cabeça pintada, et la punta orlada de amarillo et son falcones espesos, et de buena façion et mucho enplumados, et llámanlos en castilla á tales como estos coronados, et si tal lo fallares, trabaja con él, et non te duela el tiempo que con él afanares. Otros falcones neblís ay que su plumaje es auer una pinta menuda et delgada et ancha et como amarilla. Et á estos llaman en castilla falcones zorzaleños, que quieren dezir, falcones pintados como zorzales, et comunalmente 
son falcones menudos, et estos son muy bulliciosos et van mucho á las raleas et á las palomas, et de poco sosie-. go son. Et á tales como estos cárgalos de cascaueles fasta que vayan asosegando, et de estos salen buenos altaneros. Otros falcones ay que han el plumaje como preto, et son llamados rroquezes, et son duros de fazer, pero danse á bien, et salen muy buenos altaneros et garçeros et grueros; et guarda de los asañar, ca de ligero se asañan. Et despues que por el plumaje, segund que dicho hé, ouieres catado tu falcon, catar lo has por las façiones en esta manera: que aya las espaldas descargadas et buen pecho et de grand carne en el cuerpo et en las cuxas, et el çanco grueso et corto, et las manos grandes, et los dedos delgados et luengos, et las ventanas bien abiertas, et que aya unas pocas plumas que le salgan por encima de los onbrillos de cada parte, ca pocos falcones lo han; et que sea bien enplumado en la cola, que aya grand estropajo de pluma, et la pluma dura, et quanto más brauo et más esquiuo fuer al comienço, tanto mejor fiuza ten en él. Otrosí el torçuelo neblí, si lo fallares de buen plumaje, trabaja con él, ca salen muy buenos altaneros. Et son muy buena conpañía el torçuelo nebly et el torçuelo borny, ca el neblí torçuelo es muy ligero, et pónese muy alto, et el borny síguelo et sube con él, et asosiega el neblí con el borny, porque el borny no sabe yr á ralea. Et sey cierto que fazen muy fermosa boleria los dos, et yo ví un nebly torçuelo muy buen garçero al señor de la ribera, camarero mayor del rey de francia. 


\section{CAPITULO III.}

DEL FALCON BAHARI ET TAGAROTE.

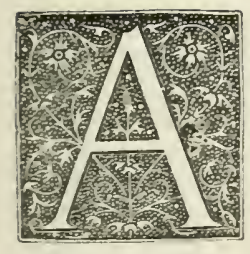

LGUNOS ternan que es sinrrazon fablar antes del falcon bahary que del falcon girifalte, por quanto los girifaltes son muy grandes falcones, et de muy gran parecer, et précianlos mucho los señores; et los que buenos salen son muy marauillosos garceros et grueros; pero non es de marauillar, ca segun dixe en el comienço de este libro, fablando en los plumajes de los falcones, el falcon bahary es llamado gentil en todas las tierras salvo en españa, segund sus condiciones et faciones et manos et dedos et ardideza, en que parece al falcon nebli, lo que non han los falcones girifaltes; ca el que bien catare et considerare el falcon girifalte, fallará que parece un grand borny. Et ctrosí, segund de suso diximos, es villano en auer las manos gruesas, et los dedos cortos; otrosí non ay dubda 
que los girifaltes, como quier que despues que son fechos son muy buenos falcones, pero al comienço son graves de fazer, ca de su naturaleza son couardes, lo que non han los baharís, ca son ardidos et apercibidos de su natura, et por ende, diré aqui del falcon baharí. Primeramente deuedes saber que los falcones baharís crian dellos los más en la ysla de cerdeña, et son llamados sardos, et otros baharís crian en la ysla de mallorcas, et son mejores; ct otros crian en romanía, et estos son granados falcones et muy buenos, et todos estos son muy buenos falcones para grueros, por quanto son muy rauiosos et caninos et trabadores. Et los falcones tagarotes, que son contados por baharís, crian allende la mar en el áfrica, et de todos los falcones baharís pocos dellos ay para altaneros, ca con la grand fanbre que muestran non se tienen en lo alto, et desque reen las anades aguadas, luego se posan et quieren pescar, et toda su ligereza es en lo baxo, pero algunos dellos salen muy buenos altaneros. Et yo ví al rey don pedro un falcon baharí mallorquin, que llamaba doncella, et trayalo vn su falconero, que dizian alfonso mendez, que era muy buen garcero, et en la rribera más alto que nebly de quantos el rey auia, que traya estonce quando yo esto vi bien quarenta altaneros neblís, sin garceros é sin grueros, que auia seys lances de gruas de neblís et de baharís, et sin girifaltes et sacres; et son los baharis muy buenos grueros de auentaja. Et yo ví un baharí sardo al rey don pedro, que traya rrui gonçalez de iliescas, comendador de santiago, que era su falconero, et sin ayuda de otro falcon derribaua la grua et la cigüeña preta, et la ansar brava, et el cisne, et la tenia fasta que llegaua el galgo. Et otrosí los falcones baharís et tagarotes son buenos grueros, et acorredores, et yo ví al rey don pedro un ta- 
garote que traya un su falconero que dezian Juan criado, et llamauan al falcon botafuego, et sin ayuda de otro falcon mataua la grua et non era muy grande. Otrosí, todos los baharís, asi sardos como mallorquines et de romanía et tagarotes, son muy buenos perdigueros, ca su ligereza es en lo baxo, et buelan el pecho por el suelo et muy fermoso, et buelan bien por el alcarauan. Et son los baharís falcones muy seguros, et no van á las raleas como los neblíes, et sus plumajes son desta manera; los baharís sardos son roquezes comunmente, et los mallorquines et de romanía son más ruuios et más granados, et mayores espaldas et más ardidos; los tagarotes son más apartados en el color et en el talle; ca son falcones pequeños mucho, que non ay de plumaje tan pequeño falcon. Et son como amarillos, et como dixe en el capítulo del neblí, á todos estos baharís llaman en francia falcones gentiles; et dicen falcon gentil de cerdeña, ó falcon gentil de romanía; et por el tagarote falcon gentil tagarote; et en aragon llaman á todos los falcones baharís monterís, et en sus faciones catar los as, como el falcon neblí, que aya derribadas las espaldas, et grand carne et grand cuxa, et buen çanco, et grand mano, et los dedos luengos et delgados, et grandes rentanas. 


\title{
CAPITULO IIII.
}

\author{
DEL FALCON GIRIFALTE.
}

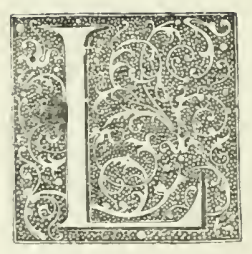

OS girifaltes son falcones que han grandes cuerpos más que ningunos otros falcones, et crian en nuruega é en aquellas partidas do diximos que crian los falcones neblís, et no se fallan en ningunas otras tierras. Crian et tráenlos á frandes, quando traen los neblís; et son los girifaltes muy duros falcones de fazer, comunalmente pocos dellos escapan que no sean gotosos, ó ciegos, ó de poca vista, ó couardes é de pequeño corazon, et son á guardar los girifaltes al comienço al poner del capirote, ca son los falcones de todos que peor lo toman, et si non toma el ome buen tiento en ello al comienço, toma con el capirote tan grand enojo, que lo non quiere consentyr, et con la porfia del que gelo quiere poner, viene á se asombrar. Et los plumajes de los girifaltes son estos: unos ay que son lla- 


\section{5}

mados blancos, en manera que han muy poco de lo gris, ct estos son finos de nuruega, et son muy preciados de los grandes señores, por la su fermosura, et salen muy buenos garceros. Et yo ví un girifalte que fué presentado al rey don carlos de francia, padre deste rrey don carrlos que agora reyna en francia, et fué tomado el girifalte en la ysla de layron, que es cerca de la rrochela, et fué tomado brauo, que es marauilla; que yo nunca oy dezir que girifalte se tome en estas tierras de aquí çahareño, et cra este girifalte tan blanco como una paloma blanca, saluo que tenia unas plumas pretas al traues en las cuxas. Et por la su grandeza et cabeça et manos et talle se conosció por girifalte, et no curaron de fazer con él que fuese garcero nin bolase por presion, saluo tener lo así por marauilla, ca el rrey lo preçiaua mucho. Otrosí, ay girifaltes que son llamados letrados, porque lo blanco han muy blanco et lo al muy preto, et bien comparado todo, en guisa que parece como libro escripto de letras gruesas, et por esta conparacion los llaman letrados, et salen dellos muy buenos. Otrosí, girifaltes ay que son llamados grises, porque lo que han preto es como una pequeña grisa, et han fermoso plumaje, et salen buenos et muy ligeros; otrosí falcones girifaltes ay que son pretos, et son llamados roquezes, et son de gran esfuerzo, pero que son feos, et destos así pretos ví uno á monsen bureo I, señor de la ribera, camarero mayor del rey de francia, et enbiáragelo en presente el grand maestro de pruça, que era tan roquez et preto, que apenas se deuisaua lo blan$\mathrm{Co}$, et cra el mejor garcero del mundo, et deues saber que girifalte que se da á bien, mata muy más ligero et

1 Bureau de la Rivière. 
mejor garça, ó grua, ó la presion á que fuere lançado, que ninguno otro falcon; que la garça mata muy alta, al sobir non face tantos tornos como el nebly, et va más derecho en sus buclos, et como quier que por la su grandeza salga pesado de la mano, pero desque comiença á caualgar en el ayre todavía cobra mejor ligereza. Et deuedes al girifalte fazer en el comienzo matar liebre, ca lo rno pierde las cosquillas que há en las manos, ca de su naturaleza son cosquillosos, otrosí cobra ligereza, et sabe sofrir el rresuelgo en el trabajar que faze con la liebre, et en alçar et venir á ella. Otrosí, es muy bueno al girifalte fazerle bolar la perdiz, por quanto la perdiz buela luengo trecho, et saca mucho el buelo al falcon, et á qualquier aue que la siga. Otrosí es bueno al girifalte bolar por la lechuza, porque monta mucho et porfia, et es le como trayna de garça para adelante. Et desque á estas cosas ouiere bolado el girifalte algund tienpo et cobrado ligereza, podras lo fazer garçero dándole sus traynas, ó echandolo con otro maestro, desque la garça se rrinda. Et algunos ay que son de buen esfuerço et de buen talante, et la matan por su voluntad. Et los girifaltes es bien de los traer sienpre en la mano, ca como son pesados, si se derraman en el alcándara podrian peligrar, et cada vez que el capirote tira quiere se afalagar con el roedero, et fazer plazer. Et quando quisicres escojer el girifalte, lo primero que farás cátale por los pies, si há clauos en cllos, ó los tiene finchados, que es comienço dello, et otrosí cátalos por la vista, como quier que sea graue de catar, ca ternan los ojos claros et avran poca vista, pero cátalo como mostrándole el rroedero, ó otra cosa, por ver si es apercibido en la vista; et por las faciones cátalo, que sea bien derribado de las espaldas, et non sea corcobado, et que sea de buena carne et de bue- 
na cuxa, et buen çanco et buenas ventanas et buenas manos, et los dedos cortos et gruesos, al contrario del nebly, et non sea cabezudo. Et el torçuelo girifalte es muy bueno, et sale buen garçero, et es muy ligero, mas es sañudo et muy delicado et malencónico, et há menester ome sofrido. 


\section{CAPITULO V.}

DEL FALCON SACIRE.

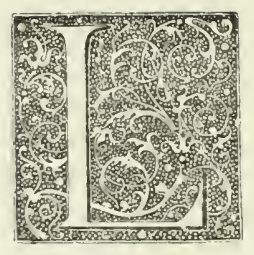

OS sacres son falcones grandes de cuerpo, et han las colas luengas, et crian en nuruega, et en aquellas partidas dó diximos que crian los neblís et girifaltes, et con ellos los traen los mercadores. Et otrosí falcones sacres ay que crian en romanía, et son muy buenos. Et de los sacres ay lo que en los otros falcones, ca dellos ay ruuios, et dellos más pretos, et más dellos blancos, et de todos salen buenos; et han los sacres en su plumaje lo que non han otros falcones, ca por muchas mudas quel falcon sacre mude, tal se finca como era antes, et non muda el color de las plumas, como fazen todos los otros falcones, saluo aquel plumaje non finca tan brozno como quando era pollo; et fázenseles unas orrladuras en derredor de las plumas que asaz poco deuisan; pero yo ví un falcon sacre, que 
era de los de romanía, et fué mio, et díle á don aluar perez de guzman, et á las cuatro mudas fizo los cuchillos mayores de cada ala así blancos todos como una paloma blanca, et todas las plumas de enderredor del cuello grandes et pequeñas, et una péñola de la cola, et perdióse, et creo que si non se perdiera, et lo pudiera ome mudar otra muda, quél ouiera muchas más péñolas blancas, fasta que por tienpo él fuera todo blanco, ca muchas péñolas grandes et pequeñas tenia ya pintadas de blanco. Otrosí, de los sacres es lo que es de los neblís, ca los que toman brauos por las tierras, que son llamados çahareños, son los mejores; pero que hay en ellos algund afan de los fazer, et salen dellos muy buenos garçeros et grueros, et para toda cosa buenos; otrosí, los sacres son buenos perdigueros, et buenos lebreros, pero que no entran en la liebre, saluo los que son tomados çahareños, como dicho auemos, et matan bien lechuza et alcarauan, et buelan mejor con viento, et páranse mejor á él que otros falcones ningunos. Et los torçuelos dellos son muy buenos éso mismo, et yo ví al rrey don pedro un sacre torçuelo, que fué del rey don alfonso su padre, et trayalo rruy gonzales de yliescas I comendador, et era muy orgulloso garcero, et han menester los falcones sacres buen tiento, et quieren sienpre andar çeuadiços, ca muy de ligero se rrebotan, et á los falcones sacres no les ponen en la rribera, porque son falcones pesados para remontar; pero en brauante et en francia buelan con ellos en la rribera; mas no son altos, et los torçuelos son mejores para ello. Et quando lo catares, para mientes que sea descargado de las espaldas, et de buena carrne et buena

1 A. Gomes de Illescas. 
30

cuxa et buen çanco, et los dedos cortos et gruesos, et la cola la más corta que pudiere ser; et las puntas de las alas luengas, et buenas ventanas bien abiertas, et non lo olvides en la alcándara, ca se fazen truhanes, et dellos enbrauecen, et la buena mano del caçador es la mejor alcándara que qualesquier falcones pueden auer. 


\section{CAPITULO VI.}

DEL FALCON BORNÍ.

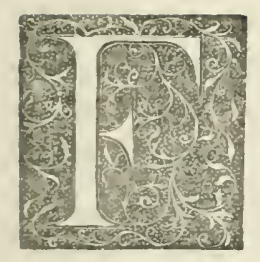

ALCONES bornís crian en muchas partidas : crian en la alta alemania et en noruega, et en aquellos lugares do crian los neblís et girifaltes et sacres, et en todas las tierras, saluo en españa, son llamados laneros, et los que traen de alemania son buenos et seguros et grandes de cuerpos, et otros bornís crian en tierra de saboya et de leon del ruedano, que es entre el enperio et francia, et son muy buenos; otros crian en castilla, en álaua, et en guipuzcua et en vizcaya, et en mena, et en losa en asturias de santillana, et asturias de ouiedo, et en galizia, et en santiago de montizon, et estos son muy buenos los de galizia, et son roquezes et muy buenos.

Et en asturias de santillana hay una muda que llaman 
tagre I, et han plumas entre los dedos, et destos desta muda de tagre ví al rrey don pedro vn torçuelo que fuera de garci laso de la vega, que dizian pristalejo, et era buen altanero, en manera que sin conpañía mataua dos pares de ánades mayores tan bien como vn neblí, et ví de los de las asturias de ouiedo un falcon borrny..... 2 torçuelo al obispo de leon don diego ramirez de guzman, et diólo al rey don pedro, et era muy bien garcero. Pero de todos los bornís los que llaman prouinciales en castilla, et en francia son llamados laneros de crao 3 , estos son los mejores, et tómanlos de paso despues de sant juan fasta sant miguel en el crao de arrle, que es en prouencia, et tómanlos en la playa de Lunel, et en florencia; et enderredor de aquella comarca que es en lenguadoc, que es en señorío del rrey de francia, et todos son llamados de crao, et son muy buenos et ligeros, et de cada año prueuan mejor, et son muy buenos para perdizes, liebre, lechuza, alcarauan, doral, garça; et destos son los torçuelos, que son llamados laneros, préçianlos mucho en toda francia para la rribera, et non curan de otros, saluo que sean de crao, et salen muy buenos altaneros, et fazen muy buena conpañía á los neblís, et sosiegan mucho con ellos, ca todo el dia andan sobre el agua, que no se parten de ally, nin van á raleas; et échanlos primero que los neblís, porque si rraleas algunas ay, fuyen, et ellos no las siguen. Otrosí asosiegan las ánades, et cuando el nebly es echado fallará la rribe-

I C. Tange.

2 A. Prima. B. Premia. C. Primo. D. Primero.

3 B. y D. Omiten esta frase. Crao, es la Crau, gran llanura pedregosa, cerca de Arlés. 
ra linpia, et buela más seguro, ca non ay rraleas á que vaya, et luego al comienço son graues et duros de fazer altaneros, ca su naturaleza no es aquella, et luego se posan, pero con los neblís, rsando de cada dia, fázense et quieren andar en buena carne. Et lo primero deuedes los traer á que buelen picaças, ca de allí toman á andar alto, et tenerse et guardar á su maestro, et á la presion, et desque algunos dias bolaren así por las picaças, echarlos as con el neblí en la ribera, et arnque se pose, non te enojes dello, ca rsando de cada dia á bolar con el neblí, él tornará á lo guardar, et desque fuere fecho altanero, dale sienpre á roer en el ánade, ca de otra manera se deue gouernar quel nebly, ca es altanero contra fecho, non sabe remontar sin le dar á rroer como faze el neblí. Otrosí as le de leuantar á su mejoría, et que esté cerca quando le leuantares, ca non puede de lejos alcançar así como el nebly, et quieren se traer en la mano, et quando son dos, fazen buena conpañía. Et en francia qualquier señor, a rnque muchos tenga, sienpre terná una copla destos, que son dos, et toman sienpre los más granados, et yo ví en paris una copla dellos, que son dos torcuelos bolantes, valer cient francos de oro; et bolauan por todas las marismas que fallasen, et son muy plazenteros, et los bornís, dellos ay blancos, et dellos ruuios, et dellos roquezes, et de todos salen buenos, et sus faciones catarlas as así : que sean bien descargados en las espaldas, et non sean corcobados, nin estrechos de ombros, et sean de buena carne, et non luengos de piernas, et buen çanco et buena cuxa et grand mano, et los dedos cortos et gruesos, et la cabeza llana et el ojo enconado 1 , et buen pico,

1 A. encouado. 
34

et la cola corta, et buenas ventanas, et buen estropajo de cola. Et como quier que dizen quel borní con qualquier vianda pasa, si tú le dieres buena gallina, ó buena vianda, ver gelo as en el bolar, et si son çahareños valen más, et quieren se traer en la mano. 


\title{
CAPITULO VII.
}

\author{
DEL FALCON ALFANEQUE.
}

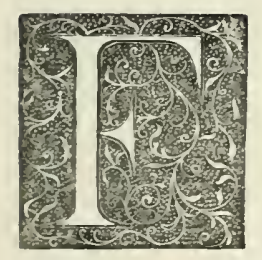

ALCONES alfaneques comumente son blancos, et las cabeças ruuias, et dellos ay más rroquezes algunos, et más como pretos, et crian allende la mar en áfrica en el regno de tremecen, et en la ysla de alhabiba; et non sabe ome que en estas partidas de aquí crien alfaneques nin tagarotes. Et otros falcones crian en el regno de túnez, que son más roquezes, et las colas luengas, et son llamados tunizos, et son como entre alfaneques et bornís. Et otros falcones ay que son llamados entrecelos, et dizen que son de boltura I de tagarote et alfaneque, et son muy buenos; pero pocas rezes pareçen. Et estando yo en alicante, que

1 A. Bultacion. 
es en aragon, ribera de la mar, llegó y una nao que vinia de la berbería, et traya muchos de los alfaneques, et conpré dellos; et el señor et maestre de la nao dióme rno, que dizia él que era entrecely, et en verdat el talle, et manos et rostro era de taggarote, mas las plumas et su color era de alfaneque, et tóuelo grand tienpo; et yo non curé de fazer dél al sinon perdiguero, et aquel fiz fazer á él muy bien, et era muy ligero, et los falcones alfaneques son muy plazenteros, et matan bien et fermosamente la liebre, señaladamente quando son dos, et non entran en ella; et la perdiz vuélanla bien, mas pocos la asientan é matan bien, et doral, et garçota, et cuerua; si son puestos á la ribera fazen lo bien; et yo vi en casa del rrey don pedro vn alfaneque torçuelo muy pequeño, que llamauan pica figo, et fuera de don enrrique enrriquez, et mataua así bien vn par de ánades sin compañía, como un nebly, et mataua cuerua preta, et de las capusadas, et un doral viniendo por el cielo, et garçota. Et todas estas cosas faze el bueno et porfiado et sufrido caçador, et los alfaneques quieren andar delgados et bien señoleros, ca luego que les da vn poco de sol se pierden, et dizen que se tornan á tremecen donde venieron, et creo que pasan allá, ca nunca oy dezir que fuese aquí tomado çahareño, saluo si tomasen á pocos dias alguno de los que se perdian así, et son mejores los alfaneques en la tierra fria, que en la tierra caliente, et son falcones que ayna cobran I clauos en las manos, et cátalos por sus faciones et figuras todas que catares al borny.

I B. y D. crian. 


\section{CAPITULO VIII.}

COMO SE DEUE REGIR ET GOUERNAR EL FALCON NEBLI, ET CIERTAS REGLAS DE PRÁTICA PARA ELLO.

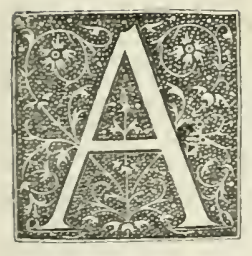

los caçadores parecerá que estas reglas que yo aquí porné para gouernar vn falcon neblí que son demás; ca dirán que non es caçador el que esto non sabe, et yo non las pongo para los que así son maestros; pero los omes quando comiençan á caçar non lo saben todo, et han menester de ver et oyr á algunos de los que más vieron et más prouaron en esta arte del caçar, et quando yo comencé á afanar con el nebly, mucho me ploguiera auer fallado vn pequeño escripto tal como este, por do me podiera regir et gouernar et guardar de fazer algunos yerros en la caça que fize, con que dapné muchos falcones, et yo era sin culpa, que non sabia más, et quando me acompañaua con falconeros que sabian el arte, paraua mientes, et por ventura en vn mes aprendia un capítulo de lo que veya. Et si quisieres, todos los capítulos que 
principalmente cunplen á rregimiento de vn nebly en pequeño espacio lo verás por aquí, et de cada dia te podrás apercibir. Et por ende los nueuos caçadores aprouecharse an dello, et por tanto porné rreglas ciertas para gouernamiento del nebly, ca en verdat este es cl señor et príncipe de las aues de la caça, et quien bien sopiere gouernar et regir el nebly, todo el rregimiento de las otras aues puede más ligeramente saber.

Deuedes saber que los falcones neblís, segund dicho auemos de suso que trayan de asuega et noruega et la alta alemania do crian, et los traen en las cocas, que vienen en frandes et á brujas, vienen muy entecados et dolientes en los cuerpos, magüer no los muestran. Et esto es lo uno por las malas viandas de que los mercadores, ó los que los traen los han gouernado; otrosí porque vienen en el nauío mal traidos et quebrantados de la mar, et han estado grand tienpo presos sin bolar et sin auer sus plumadas et sus curas, et arn quando ome los tiene et los piensa et cura dellos et buelan, asaz que fazer ha en los tener sanos, quanto más con todas estas ocasiones. Et por ende, si de tales falcones ouieres de conprar de mercaderos que así los tengan, es menester de te apercibir et catar et avisarte bien qué tomas en lo que de fuera puede parecer, et farás así :

Cuando catares el falcon, cátalo primero por las faciones et plumaje, segund dicho es de suso, et si todo non lo fallares ayuntado en vn falcon, toma lo mejor que podieres, et si al non podieres, á lo ménos lo primero et principal cátalo de buen plumaje, ca el falcon tal nunca se puede dar sinon á bien; otrosí cata quel falcon nebly con que ouieres de afanar cátalo que aya cuerpo, ca si feble es et de poca conplision, non es duradero, avnque al comienço muestre de fazer todo bien. 
Et desque le ouieres escogido por el plumaje, et por el cuerpo, cátale la boca si la tiene sana, ó si ha güermeces, ó comienço dellos, et cátale los ojos si los ha sanos de nuue.

Otrosí, cátale si tiene todas sus péñolas en las alas et en la cola, et non le fallescan del todo, que arnque sean quebradas, puédense enxerir, como quier que más valdria que fuesen sanas.

Otrosí, cata si ha alguna péñola como tijera ó cuchillo mayor quebrado por el cañon baxo en guisa que se non . pueda enxerir, ca más valdria que le falleciesen del todo, ca nasceria, et la péñola quebrada por el cañon baxo, que se non puede enxerir, está en peligro, que yo vi algunas rezes quel falcon non la mudaua por non se poder ayudar del pico en trauar della; pero acaesce pocus vezes. Otrosí cátale si ha clauos en los pies, ó comienço dellos, et si tiene todas sus uñas.

Et despues que ouieres escogido et tomado tu falcon, lo primero que farás luego este dia báñalo con el oropemente, que sea rna onça bien molido, et muy cernido et dágelo seco en poluo, echíndogelo por todo el floxel, et poniéndole en todas sus plumas, et guárdale los ojos et las orejas cuanto pudieres. Et guárdalo bien que dulcemente lo derribes, quando este baño le fezieres, et dulcemente lo tengas, et ten quien te ayude á ello, et este tal baño es bueno para el falcon pollo, ca él non tiene así plumaje fermoso, porque ayas cie auer cuydado del teñir las péñolas, et el oro pemente de cada dia faze su obra por la calentacion, et por el olor que en él ay, et linpia mucho el falcon del piojo, et es menester este baño luengo, porque jamás nunca bien podrá fazer el falcon en quanto piojo touiese, ca en el piojo que touiese auria asaz que contender. Et otrosí es bueno que este baño le 
sea luego fecho antes que comience con él á fazer ninguna cosa, ca si lo començasen á amansar et fazer conocer la mano et el señuelo et el rostro del ome, todo lo perderia, et desto naceria, quando lo cogieres para lo bañar et lo fizicres, algund sin sabor. Et por tanto, que pase lo primero en aquella malenconía et trabajo, et dende adelante fazerle bien, et no le enojar. Pero diximos aquí del baño del oropemente para los falcones pollos; pero despues que son mudados, et tienen sus plumas fermosas, si piojo ouiesen, es mejor baño de la agua et pimienta, segund que adelante diremos.

Otrosí, despues que tu falcon fuer bañado del piojo, guarnécelo de buenas piuelas et cascaueles et capirote; et las piuclas que sean de buen cuero delgado et bien adouado, et que le non aprete el çanco. Otrosí, los cascaueles que sean comunalmente grandes, segun el cucrpo del falcon; et el capirote sea de buen cuero delgado, et tresto et bien fecho, en guisa que le non llegue á los ojos, et que sea tal que lo non derribe de la cabeça quando se sacudiere. Et la primera vez que le ouieres á tirar el capirote con que vino de frandes, et le ouieres á descoser los ojos, si es tomado de çahara, ó los trae cosidos, faz que sea de noche á la candela, et estonce se asegurará más, et ponle el capirote que ha de traer dende en adelante, et faz lo velar la noche toda, et el dia non caya de la mano, nin en esos veinte dias nin noches, ó más, segund que vieres que se asegura, et non le fagas ménos; como quier quel velar toda la noche non has porque lo fazer tan afincadamente como los primeros diez dias. Pero todo esto va qual fuere la roluntad del falcon, et guarda bien que lo no escarmientes en el poner del capirote, et que gelo pongas dulcemente, et desque se vaya asegurando, trae siempre contigo roedero que le muestres, et sea 
de buena vianda; et tenga carne de quel falcon tome algunas picaduras, et vaya perdiendo esquiueza con el comer. Et quando lo touieres de noche á la candela, tírale el capirote et muéstrale el rroedero, porque vaya tomando plazer, et sienpre le torna el capirote con la mano liuiana, et non le hieras ni le des en el rostro, que lo asañarás, et si luego al comienço non quisiere comer, non te quexes por ello, ca lo non faze sinon con braueza, et el que lo velase toda la noche tenga la candela en la mano, ó delante, et non se oluide el vino al falconero, nin á los que le ayudaren. Et desque vieres que tu falcon comiença de auer fanbre, et abre la garganta como tragon, dale algunos dias de la vaca lauada en el agua tibia, fecha pedaços pequeños, et apurada de la grosura et neruios, et despues torna á darle de una polla, ó gallina, que non sea muy grande, así fecha pedazos et lauada en el agua tibia, et en la noche dale sus plumadas, et yunturas de huesos del pescueço de la gallina, ó de los nudos de la cuxa, et un poco de carne con ellos, et guárdale bien en las mañanas, que veas si ha fecho su plumada.

Otrosí, desque vieres que tu falcon cata por la mano quando le tirares el capirote por veer si tienes que le dar de comer, guisa entonces que trayas contigo en una pequeña linjavera I de lienço linpiamente una pierna de gallina, ó vna ala, et dále della algunas picaduras, et dále á desplumar, et quando él estouiere en mejor sabor de comer, tórnale su capirote dulcemente.

$E$ desque vieres que tiene ya fanbre verdadera, apártate con él et prueua si querrá sobir en la mano á toda la

I B. Aligancia. 
lonja á la lua larga ', et quando sobiere en la mano, dále buena vianda, et fazle todo plazer, et despues que tu falcon sin ninguna dubda salta en la mano, et cada vez que le muestras el rroedero, non cata por al sino por comer, entonçe encarna bien tu seíluelo de un corpanço de gallina con su cuello et cabeça et cola, en manera que de cada parte esté bien encarnado, et cata un cordel bien rezio et delgado, et ata tu falcon aparte fuera en el canpo en lugar que sea llano et $\sin$ matas, et sin piedras, porque non traue el cordel, et dále ally de comer en el señuelo fasta que lo conosca de la mejor vianda que touieres, et el coraçon de la gallina, et los sainetes, et de la pierna, et dále ally grandes vozes, et andando en derredor dél dando con la lua 2 en tierra, porque vaya perdiendo el miedo, et aprenda á lo que á de tornar, et todo esto le farás con tiento que le non asombres, et todavía en la noche dále un poco de vianda en el agua tibia et sus plumas et juntas.

Otrosí, despues que tu falcon conosçiere bien el señuelo, et lo sigue, et non lo puedes sacar dél, fázle venir por buelo al señuclo todavía con el cordel. Et cate el que tiene el falcon que lo tenga derecho en la mano, de manera que vea bien el señuelo quando gelo mostrares, et non lo echen de la mano fasta quél de su voluntad salga. Otrosí non lo scñuelen de ojo al sol, ca non verá bien el roedero del siñuelo, et podria se perder. Otrosí vaya el pico al viento et échale en lugar linpio el siñuelo sin matas, que lo vea et pose luego en él, et non lo eches de rrostro sino al traues, ó á espaldas del que señuela, et desque el falcon posare en el señuelo, ve á él muy quedo,

B. y D. lita larza.

2 C. guante. 


\section{3}

fablándole mansamente, et dále ally toda la mejor vianda que touieres, et desque ouiere comido sácalo con un rroedero, et déxale alinpiar su pico et que se sacuda, et entonce pónle su capirote, et tráelo mry sosegado en la mano. Otrosí, desque reas que ya viene muy bien al señuelo, llámalo á la tira sin cordel, arredrado de villa et de monte, et dále algunas galinas á degollar en el señuelo, encobierta la galina que la non vea, et beua de la sangre della, et todo este afan es para concertar et amansar un nebly en treynta dias para lo fazer como deues, para dende adelante que buele en la ribera. Pero todo esto es segund el tiento del caçador, et plumaje et coraçon del falcon.

Otrosí, quando feziere buen dia claro et sol, pruéuale el agua en lugar apartado al sol et en buena gamella, ó buena vasija, et está cerca dél sienpre apercibido con el rroedero en la mano, porque si vieres que non quiere sosegar, que lo tomes, et cata non lo fagas por fuerça entrar en el agua, ca se escarmentaria, antes ten algunos saynetes, et muestra gelos en el agua, porque con cobdicia dellos salte en el agua, et dágelos ally, que los coma. Et quando así le ouieres á prouar el agua, faz que tu falcon aya comido primero media pierna de gallina, ca si mucho comiese, ternia dos trabajos : de se enxugar, et de gastar lo comido, et sienpre le prueua dende adelante el agua al más tardar á los quatro dias, et desque fuese bañado ponlo á la sonbra un poco, porque con el sol, si fuese rrezio, torçer se ya las péñolas, et luego á poco espacio tórnalo al sol, porque se enxuge et piense de sí, et déxalo bien pensar de sí á toda su roluntad antes quel fagas bolar. Et si fuere tarde, et non ouo lugar de se enxugar, ponle dos candelas en la noche delante en vna cámara, et pensara de sí, et dále buena alcándara segura, 


\section{4}

porque toda esa noche pensará de sy et se sacudirá muy rezio. Otrosí la vianda de tu falcon es asaz á la mañana un mienbro de gallina, pero si fuese girifalte, ó tagarote, á estos darás á cada uno segund el cuerpo que ha. Et en la noche dále sus plumas juntas et algunas picaduras de buena vianda, et con ello todavía las plumas bañadas en el agua tibia, et guarda sienpre non le des neruios nin carne dura, ca non lo puede moler, et dura sienpre mucho en el buche. Otrosí non le des grosura, ca le enpalaga, et le engruesa la tripa que va al buche, et fázele non auer fanbre.

Otrosí, como quier que en españa non lo vsan, pero en todas las tierras do caçan con el nebly, ó con qualesquier otros falcones, señaladamente en bramante, que es en alemania, et esto mismo en francia et en inglaterra et ytalia, tienen esta rregla : quando dan de comer á su falcon, si le dan de aue biua, sienpre pasan la vianda que le dan por el agua fria, et si la carne que le dan es fria, pasan la por el agua tibia, et es prouechoso para tener el falcon sano et syn orgullo, ca la vianda muy caliente ençiende el falcon, et la muy fria enfríalo, et por tanto es bueno tenprarlo así todo. Et así lo fazen los bramançones, que son gentes de bramante, que son oy los mejores falconeros del mundo, et que más saben en esta arte, et han rrazon, porque lo vsan más que ningunas otras gentes, ca la tierra de bramante es una tierra muy llana, et de muchas lagunas, que llaman ellos fluches I, por lagunas, et ay muchas aues; et quando vienen las cocas á frandes, que traen los falcones de alemaña, et de Noruega, luego van ally los falconeros de bramante, ca es muy

I B. y D. Frachas. E. Franchas. H. Flamachas. 


\section{5}

cerca de ally, et conpran muchos falcones para los fazer en su tierra, et quando viene la quaresma, que los falcones son ya bolantes et conçertados, van con ellos á paris, et otros en inglaterra, et otros en colopnia, et en el imperio, á los vender á los señores; quien quisiere altaneros, quien quisiere garceros, de todo fallará. Et vale un nebly pollo altanero quarenta francos de oro, et sy fuese garcero, sesenta, et sy son mudados, valen más; que todo el peligro mayor de los falcones que vienen de aquellas tierras onde los traen es en la muda, señaladamente al derribar de las tijeras, ca mueren de filandras. Et por esta razon son los bramançones buenos falconeros, ca lo han por oficio, et á mí acaesció conprar dellos los falcones en paris, et los falconeros de bramante que me los vendieron venirse conmigo en castilla por sus soldadas.

Otrosí, si tu falcon ouier pequeñas ventanas, que es grand tacha, señaladamente para el falcon altanero, que há menester de venir abaxo, et alçarse, et traer el fuelgo suelto, et si tal ouiere las ventanas pequeñas, labrarlas has con cañiuete I, tirándole un poco de la cera, et desque saliere sangre, ponle ally vn poco de algodon et çeraza, et finca el falcon con buena rentana abierta. Et guárdate non lo labres de fuego, magüer que algunos lo vsan, ca es muy mal labrar, que el fuego cada dia obra más, et muchos falcones pierden los picos por ende.

Otrosí, cata sienpre de dar á tu falcon buena alcándara gruesa et firme, et que non ayan estado en ella gallinas, et avn si podieres escusarlo non pornás tu nebly en la alcándara que sacre nin borny aya estado, ca el sacre

B. Ganiuete 


\section{6}

et el borny han muy mucho piojo. Otrosí la casa sea sin humo, et sin sereno, et sin poluo, et que non esté en ella cal, porque çiega, et de yuso del alcándara esté el suelo limpio, porque veas la plumada quando la feziere, otrosí las tolleduras; et guarda sienpre que nunca dés de comer á tu falcon fasta que faga su plumada, et si non la feziere, farás como manda en el capítulo de las plumadas vicjas, et pónle sienpre la lua 1 de yuso de los piés, et vn paño de color atado á la vara, ca le es muy sano á los piés.

Otrosí, desque tu falcon fuer ya buen señolero, fazle bolar picaça en lugar que non aya árboles, ca es muy buena bolería: lo vno muéstrase á alçar et abaxar et tener el fuelgo et guardar á su maestro, et cobra grand ligereza; ct desque ovier así una grand pieça bolado, dále señuelo et de comer, et despues que en algunos dias ouicre así bolado, as menester de catar otro falcon maestro, et échale con él sobre el agua, et ande con él sus tornos, et antes quél se quiera abaxar, dále señuelo et de comer.

Et despues que tu falcon sepa andar ya sus tornos, et fueres en rribera, dexa bolar primero el falcon maestro, et agüe las ánades, et entonçe echa tu falcon, et déxalo andar con el maestro. Et así desque leuantares las ánades et siguicre el tu falcon al maestro, et aguare con él, et cobrárades el ánade, dále señuelo, et el ánade en el señuelo, et céualo ally, porque la conosca, et dále la lengua della mascada entre los dientes, et el corazon, et una pierna, et en esta guisa lo gouiernas fasta que derrauiadamente mate por sy.

Otrosí, gouernarás adelante tu falcon en esta guisa:

1 B. y D. El gusano. C. El guante. 
desque algunos dias aya andado con el maestro, quando supieres que tienes aues sobre que tu falcon buele, et sea en lugar do lo puedas acorrer, et puedas entrar por seco, non sean marismas nin muy altos juncares entre tremedales, nin aya árboles muchos, así como salzedas, que se lijaria el falcon, nin sea arroyo muy fondo, que se non pueda pasar é acorrer el falcon, mas sean arroyos llanos, ó lagunas aguisadas; et quando así fallares, ve el viento ayuso, et arriédrate de la ribera, et faz bolar tu falcon, et déxalo andar, et tomar su altura, ca si de otra guisa lo fezieres, et non tomases el viento, las ánades non esperarian tan bien, et el falcon tiraria por ellas, et podria perderse. Et faziendo esto que te digo el falcon toma su altura, et pasa por encima de las ánades, et ellas asegúranse, et reelas el falcon, et entonce conosce sobre qué buela, et todavía se pone más alto. Otrosí, no seas cobdiçioso nin quexoso de leuantar las ánades fasta que tu falcon tenga su altura, ca si de otra manera lo fezieres, tu falcon tomaria mala costunbre, et non se alçaria mucho, et ternia que aurias luego á leuantar. Otrosí, si leuantares andando el falcon baxo, et las ánades se leuantasen, el falcon no ternia altura para alcanzar, et golpar, et tiraria por el ánade á la tira, et seria grand enojo et peligro de perder el falcon; otrosí seria feo bolar, ca toda la naturaleza et nobleza et bien del falcon altanero es que sea lo más alto que pudieres.

$\mathrm{E}$ quando vieres que tu falcon está en su altura, leuanta sienpre el viento arriba, et al traués, en manera que eches las ánades por seco, ca entonces uerná mejor tu falcon, ca entiende que puede recabdar. Et sy aguare, et tirare á fuera de la ribera, dexa tomar altura á tu falcon, et torna á leuantarle las ánades, et si matare, acorre luego, et sy recabdó, llega quedo á él, et tíragela 


\section{$4^{8}$}

de las manos muy dulcemente, et caualga, et corre la ribera fasta que tu falcon se leuante; et si otras ánades y ouier, faz como primero feciste, et si non las ay, ó non quieres más bolar, da señuelo al tu falcon, et de comer todavía le da lengua et corazon del ánade, et una pierna de gallina, et está quedo con él fasta que se alinpie et se sacuda.

Otrosí, sy tu falcon andando en la ribera sale et sigue alguna ralea, et si el falcon es pollo et es en el comienço de su bolar, et está quedo, tú dále vozes, porque torne, et si non quisiere tornar, muéstrale el señuelo, et si tornare, dále señuelo et de comer, et non cures de le fazer más bolar entonçe, et ten que ha fecho asas, pues tornó á tu mandado, pero si el falcon es ya bolante, et sabe lo que ha de fazer, et sale como dicho he, et torna, déxalo andar, et si ánades ay leuantaren, faz como deues.

Otrosí, cata que non fagas bolar tu falcon sobre aues menudas, et sobre poca agua, ca quando el falcon viene á golpar, non falla así grande una çerçeta, et da en tierra et lijase. Pero si el agua fuere mucha, así como grande laguna, et ouiere y trullos et çerçetas, et alçaderas et de tales aues menudas, faz bolar tu falcon, et leuanta gelas, ca todavía tornan al agua, et en esto se afeytan mucho los falcones nueuos, en uenir abaxo, et alçar, et engolosínanse mucho, et desque una grand pieça ouieren así bolado et acuchillado en ellas, dále señuelo cerca del agua et dále de comer, et non cures, aunque non recabde alguna dellas.

Otrosí, si las ánades estouieren en seco, non fagas bolar tu falcon fasta que entren las ánades en el agua; ca en otra manera leuantar se yan, et el falcon tiraria et perderia su buelo. Pero si vieres. que están orilla del agua, espéralas que entren en el agua, et si vieres que non quie- 
ren, et non fallas al, et tienes borny torçuelo altanero, fazlo bolar, et por auentura entraran entonces en el agua las ánades, et si se fueren, el borny non las seguirá, et así escusarás de non auenturar el nebly, et comunalmente esto fazen las ánades en el tienpo de las grandes eladas, que non pueden rronper el agua. Otrosí, están las ánades fuera de los arroyos et lagunas quando ha llouido mucho, et ay muchas aguas sobradas, en guisa que en los prados están todas las yeruas cobiertas de agua, et las ánades posan et piensan de sí, et non tienen si non los piés cobiertos de agua, et non entran en los arroyos, por quanto el agua corre rrezio, por la mucha agua que traen, et es peligro, et entonce vela al falcon, ca están las ánades tanto como en deseo, et guardarte as de fazer bolar á tu falcon en tal lugar.

Otrosí, pon todo tu saber, et toda tu acucia en que tu falcon rebuele et remonte, et en esto afana quanto podieres, ca esto es el cabdal del nebly. Otrosí, guisa, quier mate quier non, de señuelo, si non estando tu falcon bolando algund poco alto, como quier que quanto más alto estudiere quando el señuelo le dieres, será mejor. Et si estouicre posado en tierra, ó en áruol, ó en casa, espéralo fasta que se leuante, et caualga la ribera et dále bozes, et desque se leuantare, et andudiere un poco sobre el agua, si ánades non hay quel leuantes, entonçes le dá señuelo, et de comer, et de roer si quisieres yr á cazar otras ánades.

Otrosí, si acaesciere que las ánades desque son golpadas, ó aguadas, et se encierran así en el agua, con el grand miedo del falcon non quieren salir, et ay falcones así rauiosos et caninos, que cuando las veen así vencidas et rrendidas en el agua que se posan en la rribera cerca dellas, et quando las veen lánçanse en el agua por cuy- 
darlas tomar, et llaman los caçadores á esto pescar; et esto escúsalo con el rremedio que se podiere poner, et non ay otro cobro si non lo más ayna que podieres, ó con vara, ó con arrexaca, ó vallesta, que cobres el ánade, pues anda muerta. Et caualga et corre la rribera, porque tu falcon se alce, et desque lo vieres alçado, dá señuelo, et si se ouiere mojado et estouiere en tierra que se non pueda leuantar á bolar, tómalo et non le des esa ora de comer, quier mate quier non I, et dende adelante si vieres quel falcon á menudo faze esto, antes sufre que se pierda el ánade, et dá señuelo á tu falcon, antes que venga aquello, que es una cosa que los falcones fazen á menudo desque á ello se vsan, et todavía para mientes si lo fazen con grand fanbre, porque anda baxo de carne; et si aquella fuere, súbelo en la carne 2 .

Otrosí, véngate sienpre en mientes quel dia quel nebly nasció para tomarlo ome, et caçar con él, que ese dia nasció la gallina, et sienpre la trae contigo biua; et avnque tu falcon mate otras presiones et le des algunas picaduras dellas, ó el corazon, pero la gorja sienpre gela faz de gallina, ca lo trae siempre tenprado et sin orgullo, ca la carrne de ánades, et de aues de rribera, et otras qualesquier presiones es mochina 3 , et saluaje et orgullesce el falcon, et fínchelo de orrura + , et non anda mandado al señuelo, et cura de raleas.

Et la gallina que ouieres á dar á tu falcon, non sea muy vieja, et cata que sea sana, ca si doliente fuese, ó pepitosa, seria gran dapno para tu falcon.

\footnotetext{
I A. Omite esta frase.

2 A. Omite esta frase.

3 B y D. Manchina.

4 B. Ferura. D. Ferma.
} 
Otrosí, el dia que tu falcon no bolare en rribera, ó por otra presion, non oluides el señolar á la tira si buen tienpo feziere, que non y lueua, ó faga grand viento, ó niebla, ó estouieres en monte. Ca entonce seria peligro, ca lo podrias perder, et dále señuelo cabo ty, et de comer, pero si á la tira señolares, et touieres gallina encobicrtamente, dágela á degollar por la boca, et beua la sangre, ca aquella sangre de gallina es muy sana, et así lo oy al visconde d'ylla de aragon, que es muy caçador et sabedor de nebly, et dize que es muy sana la sangre de la gallina, por recelo de las filandras et filomeras, et porque toma otrosí el falcon grand creencia en cl señuelo.

Otrosí, de todas las aues yo non fallo de tan diuersas et tantas naturas como ánades, ca y son contadas abocastas, ánades reales, et ánades gentas, capirotadas, ginetas, trullos, golondrinos, alçaderas, rayllos, negretas, cercetas, et otras muchas, et á todas estas et de tal natura farás bolar tu falcon de una manera, faziendo bolar primero tu falcon, et que tome su altura, et despues leuantar, pero á todas las otras presiones, saluo sisones, así como á grua, garça, aberramia, martinete, cuerbo, taluo, alcarauan, lechucha, bitor, echarás á braço tornado.

Otrosí, antes que los falcones pollos entren en la muda, quando son pollos, es bueno en el mayo fazerlos bolar sobre los sisones, ca los fazen ligeros et altos, et á estos farás primero bolar tu falcon, et despues leuantarle los sisones, et si recabdare, tíragelo cortesmente de las manos, et caualga et fázgelo rrebolar. Et sy más quisieres, que buele por otros, sy los ay, si non, darás señuelo; otrosí en aquel tienpo es muy buen bolar á los martinetes. 
Otrosí, quando tu falcon quisieres que buele por el auerramia, cata que non faga grand viento.

Otrosí, el tu nebly pollo fazlo bolar algunas vezes sobre las perdizes, ca los faze la tal bolería sobre las perdizes muy altos et muy redondos, et toman los falcones en ello muy grand golosina et grand sabor, et buele como te dixe que deue bolar sobre los sisones, et si rrecabdare tíragela de las manos, et non le des de rroer, et caualga, et rrebuele, et quando vieres que asaz há bolado, et está alto, antes que desenballeste á se abaxar, dále señuelo et de comer, et guarda quando quisieres que tu falcon buele así por perdiz, non trayas sinon un podenco, ó dos, et bien mandados, et eso mismo non le fagas bolar en logar que aya árboles muchos, ca se podria el falcon lisiar quando viene al golpar.

Otrosí, acaesçe muchas vezes que se toman los falcones çahareños tan tarde, en manera que finca muy poco tienpo dende al tienpo de la muda, et es breue eso mismo el tienpo para lo fazer et caçar con él, et para esto conviene que fagas así: que todo ese verano non cures de lo poner nin asosegar en la muda, mas por las mañanas frias et tardes lo faz bolar por sisones, por alcarauan et ánade, et non cures de al saluo de pasar así el tienpo, siquier bolando et dando señuelo, et eso mismo por el martinete es buen bolar. Et desque vieres que ya derriba mucho, así de las alas como de la cola, tráelo en la mano, et sufre quanto podieres de lo non poner en la muda; pero desque vieres que las péñolas vienen en sangre, porque seria grand peligro estonçe, sosiégalo en la muda. Et otrosí, el dia que tu falcon no ouier de bolar, aquel dia en la mañana pónlo en el prado, en logar apartado sobre una piedra bien atado á su lonja, et ally folgará et pensará de sí, et cata quel logar dó le así ouieres á 


\section{3}

poner, que sea entre paredes, non sea en el canpo, porque veria las aues que atrauiesan por el çielo, et non asosegaria. Et tú non te partas dél con el rroedero, porque si vieres que non quiere asosegar, que lo tomes, et este poner así en el prado non lo vsan los caçadores en castilla, mas el falconcro de bramante non lo escusaria por cosa del mundo, ca dize él que su falcon há menester de pensar de sí, et tomar plazer, et que le es mejor allí que non en el alcándara.

Otrosí, como dixe primero, sienpre guarneçe tu falcon de buenos cascaueles et de buenas piuelas, et buen capirote; ca si el capirote se dapna et moja en los ojos, podria perder la vista, et auer nuue, et eso mismo escarmiéntalo en manera que aborresce el capirote. Otrosí, la mala piuela, de mal cuero, ó muy apretada, fázele finchar los piés, donde le rrecrece gota ó clauos. Otrosí, los cascaueles sean buenos et doblados de milaña, et si tu falcon es bulliçioso, et sale á menudo de la rribera, et va con la ralea, cárgalo et échale quatro, ó si menester fuer seys, segund vieres el cuerpo del falcon et su orgullo. Et algunos caçadores ay que quando cargan su falcon por ser orgulloso et sale de la ribera, que le ponen cascaueles en la cola, et aquello paresçele muy mal et feo; ay otros que le ponen cascaueles llenos de plomo, et esto me parece muy peligroso, que el falcon podria por ende mancarse muy ayna, et por ende es mejor cargarle de muchos cascaueles, que más enpachan al falcon et lo enojan, et lo farán asosegar por ser muchos antes que por la pesadura que há, en quanto son quatro, ó seys, segund cumple : et yo así lo vsé et lo querria vsar, avnque no son muy buenos, no le enpesçe tanto que suenen. Pero quando ouiere á traer los cascaueles que le cunplen, quando andouiese bien ordenado el falcon, los 
cascaueles se atan primos et gruesos, vno prima et otro bordon, pero sea tan grande el vno como el otro, que fagan buena melodía; et son buenos, lo vno el falcon paresce bien quando buela, et lo al las ánades et aues sobre que bolare más se asombrarán; lo al, si perdieres el falcon, fallarás más ayna rastro dél, ca lo oyen muchos de los que andan por la tierra, et poderás tomar et saber tiento dél. Otrosí, no se te olvide de traer sienpre contigo capirote sobrado, porque si perdieres el capirote quel falcon trae, que acaesce á menudo, que tengas de que te acorrer, ca de otra manera verte yas en grand enojo, et peligro, et quebrantamiento del falcon.

Otrosí, si perdieres el tu falcon, serás bien diligente á le buscar, et non te enojes dello, et lieua contigo gallina biua et tu señuelo bien encarnado. Et si fué con rralea, cata el tiento de la tierra que leuó, et cata si alcançó, et guarda bien, ca muchas vezes se encubren desque alcançan con la ralea, et callan los cascaueles, que non suena nin come fasta quel ome pasa. Et si otro tiento non tienes, cátalo viento arriba et á las rriberas, ca ally recudirá, et si lo cobrares et touier ralea, tíragela de las manos en manera quel entienda que te pesó. Et si alguna noche durmió fuera de tu poder, cárgalo de cascaueles fasta que veas que es asegurado, et si quando lo buscas rrecudier á tí al señuelo, fazle quanto plazer podieres, et dále la gallina á degollar en el señuelo.

Otrosí, rrequiere á tu falcon que non traya grand pico, ca lo vno paresce mal, et es le dapnoso, ca non come como deue, resolla et cárgase de agua; et quando le mucho así crece, leuántansele esquinas, de que viene á perder el pico et aportellarse.

Otrosí, quando le fezieres el pico, fazlo con buen tiento, et non saques sangre, nin le llegues al maslo. Otrosí, 
las vñas, si altanero es, tájagelas, et tráyalas cortas, et si garcero es, non gelas cortes.

Otrosí, faz sienpre bolar á tu falcon por la grand mañana, madrugando bien con él, et esto es lo vno buena costunbre, et otrosí las rraleas nin águilas non parescen, et arn otrosí lo farás bolar á las tardes, ca el nebly dos vezes al dia quiere bolar.

Otrosí, quando touieres nebly, que de auentaja sea alto et rredondo en la rribera, por mi consejo en aquello lo manternás; et non lo farás garcero, ca despues que garceros son, dexan mucho de la altanería, et el cabdal et sotileza de la arte del nebly todo es el altanería, et tarde falla ome tal falcon para ello qual quiere, et garcero ayna se faze el falcon, et los caçadores sienpre contaron la garça por rralea.

Otrosí, tu falcon duerma en tu cámara, ó del que lo touiere en carga de curar dél, et tenga candela toda la noche. Et en españa vsan los falconeros dexar sus falcones sueltos, porque sy de noche se sueltan del alcándara, que acaesçe soñando que andan á caça, seria peligroso, et algunos ay que se perdieron así. Et en francia, et en aquellas tierras átanlos, ca dizen quel falconero non deue tener su falcon tan arredrado de sí, que le non oya, et si estouiere suelto, que podria dar en la pared, ó en alguna otra cosa, et lijiarse, et cada uno vno pone buena rrazon por sy. Pero yo sienpre lo dexé suelto, et çerca de mi cama, si es falcon de que me pagué.

Otrosí, quando tu falcon tomare alguna presion, así como á garça, ó otra presion sobre que le as de dar á comer, non le dexes comer luego fasta que pele, ca el falcon está encendido, et la carne de la presion arde, et ayúntase todo, et faze grand dapno al falcon. Et desque una pieça así pelare, dále de comer et guárdale de la san- 
gre, ca non le es buena, ca, como ya dixe, son las presiones saluajes, et orgullesce el falcon con su sangre; et arn con la carne si mucho le das della; et deues lo guardar desto, ca el nebly de su naturaleza es brauo por el ardideza et esfuerço que en él ay, et por tanto es menester de lo gouernar tenpradamente, pero dizia juan ferrandez burriello que el falcon que no descendia derrauiadamente en la ribera, que era bien darle algunas vezes á comer el pecho del ánade, porque tomaua grand creencia et sabor. Et yo non dubdo que esto es verdat. Peroá la tira es más presto el nebly de seguir el ánade, que primero feziera si esto le fezieres, et podrás lo antes perder. Pero si el falcon es tan duro de fazer que non desciende como deue, bien es alguna vez darle así de comer en el ánade, et sea muy pocas vezes.

Otrosí, quando tu falcon tomare ralea, así como corneja, sison, paloma, ó otra contra tu voluntad, sácagela de las manos, en manera quel entienda que te pesó dello, et non le fagas bien ninguno, mas luego le pones el capirote, et no le dexes bolar fasta que esté así una grand picça.

Otrosí, es bien algunas vezes dar á tu falcon de la liebre caliente, ca es vianda bien liuiana, et que remonda et alinpia mucho el buche del falcon. Et esto sea una vez en el mes, et dále della una gorja, mas guárdale de la sangre della, ca seca es mucho, et faze huélfago; et quando el falcon mucho trabaja es buena vianda, et ry que rramir llorenço, comendador de calatraua, que de suso fize mencion dél entre los caçadores et grandes falconeros, et fué buen caçador, et especialmente fué muy buen acetrero, et quando tenia açor de Noruega, et fallaua garça en tajo, que es rio caudal 1, et moraua cerca delly, él fazia

I B. U en otro rio que fuese caudal. 
la guardar la garça, et con los falcones alfaneques que tenia yua á buscar la liebre, et despues que la tomaua, tomaua estonces su açor, et yua á echar la garça, et su açor la tomaua en guisa que cayese en el agua grande, et se mojase. Aquel dia dáuale el corazon de la garza, et todo el papo le daua de la liebre, porque era vianda buena et liuiana. Et el açor llévaselo luego al buche, et dezia que asaz tenia el açor de trabajar en se enxugar, et por tanto auia menester non ser gouernado de vianda si non liuiana, como es de liebre.

Otrosí, quando tu falcon quisicres fazer garcero, farás así : si tú vieres que tu falcon tiene ojo por la garça, et llega á ella, mas non pega con ella, abáxale un poco de la carne, et dále fanbre. Et si vieres que con esto non quiere trauar della, entonces cata falcon maestro que sea buen garcero. Et quando vieres que el falcon maestro buela, et la garça se rrinde, entonce tira el capirote al tu falcon, et déxalo bolar, et luego se ayuntará con el maestro, á lo que vee rrendido, et si la garça muere, fazle ally todo plazer que pudieres, et dále en la garça á pelar, que la conosca, et dále el corazon della, et cañadas, et una pierna de gallina, et coma algunas picaduras en la tabla de la garça. Mas jamás nunca des á tu falcon fartura I de la carne de la garça, ca es muy viscosa, et mochina, et enpalaga mucho, et aborrécenla los falcones muchas vezes por ende.

Otrosí, desque tu falcon aya comido en cinco ó seys garças, et la mata denodadamente sin maestro, dende adelante dále garça esquiuada que algun falcon la esquiue, et la faga remontar. Et desque con rrazon fuer alça-

\footnotetext{
2 A. Fartacion.
} 
da la garça et alta, entonce echarás tu falcon, ca no le deues usar á matar garça baxa, que aquello querria él.

Otrosí, quando echares tu falcon á garça ó á otras raleas, echarás viento arriba, al contrario que faces á las ánades, porque la garça luego toma el viento ayuso, et falla el falcon en encuentro. Otrosí, non eches en rio grande, ó en lugar que lo non puedas acorrer. Otrosí, quando ouieres de fazer que tu falcon buele por garça, guisa que non aya estado al sol, et que aya buena fanbre, et si cascaueles grandes traxier, descárgalo, et buele con cascaucles liuianos.

Otrosí, quando touieres falcon garcero, el fallares gar$\mathrm{za}$, et ánades, todo en vno en la ribera, cerca lo vno de lo al, estonce farás primero leuantar las ánades, et echarlas de ally, et otrosí rraleas si las y ay. Ca en otra manera, si echares tu falcon á la garça, et andando con ella se leuantasen las ánades, el falcon vernia á ellas et dexaria la garça; et si non viste las ánades, fasta que tu falcon bolaua, guarda quanto podieres non le leuantes las ánades, que ya estonces non ay otro rremedio. 


\section{CAPITULO IX.}

COMO SE DEUE ALINPIAR EL FALCON DEL PIOJO.

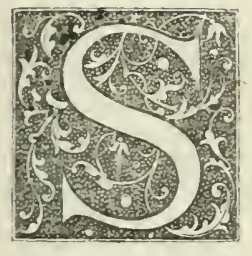

USO auemos dicho que los falcones, así los que traen de noruega, que vienen de frandes, como los que toman çahareños, que lo primero que los deues fazer es vañarlos del piojo. Ca non es dubda que los que traen de flandes, por la conpañia de muchos falcones que vienen en vno, otrosí los que se toman brauos, han piojo de las aues que toman, en que se çeuan cada dia, et fasta que los bañes et alinpies del piojo non pueden estar en su sabor, nin farias dellos lo que quisieres; ca luego que le da el sol et el piojo bulle, tanto tiene que ver en tornar ally, que non cura de al, ca la pluma se le calienta, et el piojo muéuesele, et fázelo y entender et á las veces perderse. Et como dixe, quando son pollos, el oropemente es buen baño para ellos. Pero desque son mudados, et están bien vestidos 
de fermosas plumas, non los quieren los caçadores teñir del oropemente, segund dicho es en el ochauo capítulo, luego en el comienço. Et para lo alinpiar, quando tu falcon mudado sintieres que tiene piojo, ca gelo verás que toda la noche trae los cascaucles et non sosiega, rascándose con los piés, et sacudiéndose á menudo, et algunas vezes son tantos, que los verás salir al sol por encima de las plumas, et tomarás para un falcon una onça de pemienta bien molida et cernida, et vn quarto de onça de fauarraz molido, et átalo en un trapo et pon en un baçin, ó en vna gamella pequeña del agua tibia, et algund vino blanco, quanto el quarto, et faz salir toda la fuerça de los poluos de la pemienta et fauarraz que tienes en el trapo en el agua, et despues pon vn paño de lino en el baçin, et coje tu falcon dulcemente, que lo non apretes, porque non se fiera en los onbrillos et en las espaldas, ca tiene ally los huesos et poca carne, et ten alguno que te ayude, et derriba tu falcon ally, et mójale bien todas las plumas con el agua, así buelta con el poluo de la pemienta et fauarraz, como se dixo, et desque lo ouieres así vañado et requerido, enbuéluelo con un paño de lino linpio, et esté así encamisado una pieça encima de vn fazeruelo, et despues desenbuéluelo, et tómalo en la mano, et tenlo al sol fasta que se vaya enxugando, et veas salir el piojo, et tíragelos luego con vna caña así como fueren saliendo, et dende á quatro ó çinco dias pruéuale el agua dulce, porque se vañe si quisiere. 


\section{CAPITULO X.}

COMO SE DEUE PURGAR EL FALCON DEL AGUA COMUN

QUE NO ES VIDRIADA.

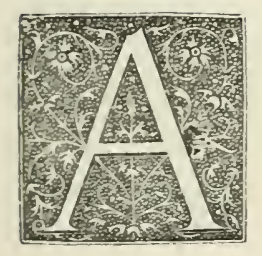

CAESCE muchas vezes, segund dicho auemos, que los mercadores conpran et ayuntan falcones para vender, et non curan de al sinon de los gouernar á la menor costa que pueden. Et por tanto non les dan si non malas viandas, et por esto, et por estar encerrados que non veen el sol nin les prueuan agua, non están sanos, et cárganse de agua. Otrosí, bien así quando los caçadores los trahen por les non dar á tirar, ó les dar casa con fumo ó sereno, cárganse de agua, et esta agua es ligera de curar antes que se vedrie, et conoscerlo as en esto : que le verás quando le das de comer et tira, que le cae agua por las narizes, et estornuda, en guisa que al caçador que le da de comer roçia el rostro con el agua que sacude. Et si el agua que tú vieres es tan cargada que tiene las señales que dize en 
el capítulo onzeno, que es el siguiente deste, que fabla del agua vidriada, farás et curarlo as como ally dize. Pcro si non es tanta como dicho hé en este capítulo, dále fauarraz bien mondado et linpio, apretado en vn paño en el agua caliente, en guisa, que salga tan claro que apenas tenga leche; et ponle en cada ventana quatro gotas, ó cada tres, segund vieres la conplision del falcon, et muéstrale un poco el sol, et tíralo luego á la sonbra, et esté quedo en una alcándara fasta que faga sus bauadas, et ponlo de sí en vna cámara fria, et bien tarde dále de comer de vna pierna de polla, et para bien mientes quando así ouieres á purgar tu falcon, que esté bien rezio, ca de otra manera seria grand peligro. Et otros dexan de darle el fauarraz, et úntanle al falcon los paladares con la miel, et despues frégangelos con oruga molida, et fázenle purgar del agua, et es más sin peligro, et por escusar dende adelante sienpre desto, dá siempre á tu falcon á tirar et desplumar dos vezes al dia, et guárdalo de le non dar sereno de noche ó fumo ó mala vianda, et así nunca se cargará de agua para que lo ayas de melezinar. 


\section{CAPITULO XI.}

COMO SE DEUE PURGAR EL FALCON DEL AGUA VEDRIAIA.

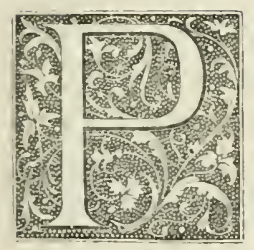

ORQUE la cabeça es principal mienbro de todo el cuerpo, et cuando este mienbro es enfermo, todo el cuerpo padesce, por ende digo que esta agua vedriada de que este capítulo fabla, es principal dolencia de las dolencias que se engendran en los cuerpos de los falcones, et quando esta dolencia es en la cabeça del falcon, luego el falcon es tollido de las otras dolencias et dolores; et tú conocerás esta dolencia en esta manera : pára mientes al rrostro del falcon, et verás su senblante triste et los lagrimales de los ojos finchados, et el cueilo grueso; et quando se debate, ó dexa de bolar, tienta con la boca, et da en él. Otrosí, qnando come, non lo fallarás así valiente como solia, nin en el desplumar et mesar como antes que esta dolencia ouiese, et esta dolencia se cura así: 
Toma en la noche, desque non touiere papo, et échale del agua tibia con vn poco de vinagre en las ventanas, et guárdate quel vinagre non sea más saluo quel agua sea vn poco azeda, et ponlo en el alcándara, et déxale sacodir, et desque vieres que dexa de sacodir, tómalo en la mano, et dále á tirar por un rroedero, et desplumar, et otro dia toma la miel en terron vn poco dura, et métele della en la boca, et despues que gela dieres atápale la boca, teniéndole el pico con la mano fasta que lo lance por las ventanas, et despues ponlo en el alcándara, et sacudirse há de toda aquella agua, et quando le metieres esta miel, non gela farás yr al vientre, quel seria grand trabajo, et dále vn poco de comer ese dia et tarde et en ese mesmo dia á la tarde, desque le dieres de comer, pruéuale el agua, et beua della si quisiere, et toma el espic et los clauos de girofre, et la canela, et flor de canela, et átalo todo en vn paño linpio, et ponlo en vna jarrilla pequeña, et fínchela de agua, et fazla feruir fasta que tome sabor de las especias, et desque fuere cocida, déxala atibiar de guisa que sea tibia, et dále la pierna de la gallina mojándola ally en aquella agua, et una ala de gallina cada dia, et el agua sea sienpre tibia cada que así lo ouieres á dar de comer.

Otrosí, deues saber que desta agua se faze otra agua peor que es más vidriada que la suso dicha, ca á esta primera que fasta aquí he fablado, non le deues fazer otra cura ninguna, saluo la que dicho hé. Pero esta otra agua vidriada tú la conoscerás por las señales que te he dicho, et demás verás vna señal, porque la puedes mejor conoscer. Sabe que ally do dixe de suso, que le verás los lagrimales de los ojos finchados, sabe que en ese lugar le verás fazer como las fuelles que finchan et desfinchan, et quando el falcon más se debate, tanto aquellos lagrima- 
les más fazen aquello; et demás pára mientes et verás en las ventanas del falcon como muermo cuajado, et non viene fuera sobre el pico, et á esta dolencia desta agua vidriada farás así: toma un fierro fecho por esta figu-

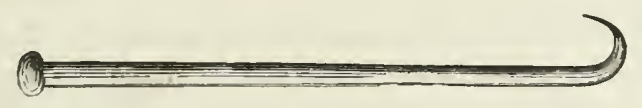

ra que está aquí figurada, et que sea tan luengo, que quando lo escallentaren de la vna parte, que lo puedas tener de la otra con la mano sin te quemar, et seria asaz vn xeme de luengo. Et este fierro tiene de la vna parte vn boton, et sea tan grande el boton como la cabeza del alfiler, et es tal como el fierro con que labran las bestias, et caliéntalo bien en el fuego, et derriba el falcon muy mansamente, et ponle aquel boton bien caliente en in foyo que le fallarás entre el ojo y la ventana, et por tantas vezes gelo pon quel boton vaya dentro á las entrañas I de las narices, et así de la otra parte. Otrosí, le deues poner otro boton suso en la cabeça entre amos los ojos, et esto fecho, deues tener vn poco de miel, et póngelo en la boca, segund dicho hé de suso, et que lo lançe por las ventanas, que non vaya al vientre, et en otro dia deues facer vn saquete de lienço tan grande como tu palma, et fínchelo de rrosas secas, et cuézelo en rna olla pequeña nueua llena de agua, et fazlo feruir. Et desque fuere cocido, déxalo atibiar, et faz otros dos saquetes tan grandes como aquel de las rrosas, et fínchelos de mijo, et que sean bien cosidos en derredor, et pon una teja en el fue-

1 B y D. Entradas. 
go, et fazla bien caliente, et desque fuer bien caliente, tírala del fuego, et derriba tu falcon sobre vn cabeçal, et escalienta aquellos saquetes de mijo en aquella teja, en guisa que se non quemen, et desque fueren bien calientes, ponle el saquete de mijo por ençima de la cabeça et de los ojos et de las orejas et sobre el pico et sobre lo llano de la cabcza, et desque el vno fucre frio, ponle el otro caliente, por tantas vezes, que la cabeça del falcon sea bien escalentada. Et desque la cabeça del falcon fuere bien caliente, toma el saquete de las rosas, que non sea más caliente de quanto lo puedas sofrir, et caldéale la cabeça et los lugares sobredichos, poniéndole ally el saquete de las rrosas. Et dale ese dia de comer vna pierna de gallina mojada en el agua del espic, que sea tibia, por la guisa que suso he dicho, et este suadório farás de tres en tres dias tres rezes al dia, et en el dia luego siguiente, despues del lauatorio, le darás tres píldoras del açéuar çecotrí, fechas por esta guisa : tomarás el açeuar çecotri, et muélelo bien, et toma el çumo del finojo, et echa gota á gota en el açéuar de guisa que non sea mucho muelle, antes sea vn poco duro, et faz entre tus manos las píldoras tan grandes como garbanços, et dale luego tres dellas, et si non fuer tienpo de auer finojo, tomarás del agua del finojo que tienen los buticarios, et estas píldoras començarás á dar en el sobredicho dia, et dende adelante de tres en tres dias. Así que sean dadas en nueve dias nueve píldoras, tres píldoras cada vez, et dárgelas as por esta guisa: toma la tripa de la gallina, et láuala, et mete en in pedazo de la tripa vna píldora, et así las otras, et mete gelas por fuerça en sus términos, segund dicho hé.

Otrosí, desta dolencia mesma que de suso dixe acaesce por tal figura, que esta agua vedriada atapa los caños, 
así de las ventanas et de ojos et de nariçes, et esta agua non ha por do salir, et tórnase á la cabeça donde se engendró, et por fuerza del atapamiento de los caños pónese sobre el meollo, et faze perder la vista al falcon, et viénele vaguido, et cae en tierra, et non se puede leuantar, et tuerçe la cabeça, et tremece, et paresce que es demoniado, et á esta dolencia acorrerás con las melezinas que de suso auemos dicho para la primera et segunda dolencia, et demás labrarlo as en las ventanas para le fazer las ventanas mayores. Et toma vn fierro luengo et delgado, sotil como alesna, fecho bien caliente, fecho en esta guisa :

Et con este fierro le pasarás las narizes, et sea bien caliente, et pase fasta el mango, et el mango sea de fierro mismo, et sea bien polido, et bien limado, et tan luengo todo el fierro como un palmo, por el calentar, et porque lo podrás mejor manear para labrar con él, et pase las uentanas de vn cabo al otro; et despues toma los otros fierros sobre dichos et figurados en este capítulo para la primera et segunda dolençias, et caliéntalos bien, et quema en las fuentes sobre dichas, otrosí en la cabeça, entre amos los ojos ençima, et despues ponle vn boton caliente en el testuço, do se junta el pescueço con la cabeça, et fazle las otras curas sobredichas, segund dicho he. Et deues saber questas dolençias sobredichas se engendraroṇ por muchas maneras et razones : et la primera rrazon por las malas viandas de carne desolladiza et non fresca que dan á sus falcones algunos caçadores; otrosí, por los 
non dar á tirar á desplumar; otrosí, quando las aues vienen enojadas en el tienpo de ynuierno, et son puestas en alcándaras malas et delgadas et non firmes, et los falcones non osan pensar de sí nin sacudirse; otrosí, en casas de fumo; otrosí, non son puestos al sol, nin son purgados quando les cunple, nin son puestos en el agua; et quando faze tienpo para ello non los fazen bolar, nin los dan señuelo á la tira. Et destas cosas de malos gouernamientos crecen estas dolençias, et ellos mesmos á las vezes son engendrados destas dolencias suso dichas. Por la qual razon cunple á los caçadores que sienpre se reuean en sus falcones como la mujer en el espejo, por veer sy paresce bien ó non, et á tal deue ser el caçador con el su falcon, para ver si se le muda el senblante, ca si algund enojo ha, luego el falcon muda el senblante. Et desta dolençia desta agua vidriada, de que tanto carga, que es menester de facer estas obras, pocos falcones guarecen. Pero yo vy á juan ferrandes burriello fazer esta cura á vn nebly del rrey don pedro, que llamauan calahorra, et trayalo vn su falconero que auia nonbre ferrand garcía el romo, et vy lo guarescer, et despues matar muchas garças, et esto digo, porque non desesperen de melecinar su falcon los que este libro touieren, ca non puede ser ménos auentura que estar en la auentura que lo tiene ome por perdido. 


\section{CAPITULO XII.}

DE LA PURGA COMUN PARA PURGAR EL FALCON DEL CUERPO.

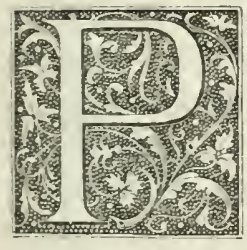

OR muchas maneras acaesçe los falcones auer menester de ser purgados en los cuerpos, especialmente luego que los ome conpra de los mercadores, por las malas viandas que han comido; otrosí, por el grand tienpo que los han tenido ençerrados, et están cargados de malos humores ; otrosí, quando los falcones purgan de la cabeça tragan bauada, et agua de aquella que echan quando les dan á sacodir, et han menester de ser alinpiados dello, ca quando los falcones non están purgados, non han verdadera fanbre, nin los puede ome ordenar así como cunple, nin andan obedientes al señuelo, nin curan de fazer bien ninguno. Otrosí, les recreçen otras dolençias mayores, por donde pueden peligrar, et por esto conviene los purgar, si los falcones están rezios. Et verás sus señales del que lo ha 
menester en esto: lo primero, que estando en su buena carne qual deue, non ha uerdadera fanbre, nin buela como deue, et desecha las presiones que solia tomar, et si lo non face por orgullo de estar muy grueso, ten por cierto que lo ha por non tener el cuerpo purgado. Otrosí, fazen las tolleduras feas et de mala color, et con mucho preto, como estierrcol, et mal ordenadas. Et quando esto vieres, farás así: toma rn tártago, et dágelo, segund que todos los caçadores gelo suclen dar, catando el cuerpo et la conplision del falcon, ca rno ha menester más granos que otro, et desque gelo ouieres dado, luego le prueua el agua en ayunas, et beuerá si quisiere, et despues que rna gran pieça esté sobre el tártago, dale rna pierna de polla, et por quanto el falcon finca fatigado del cuerpo, dende á dos dias dale su açúcar cande, poniéndogelo en la boca en tres ó quatro pedaços; et pruéuale el agua en ayunas, et desque vieres que non tuelle del açúcar, dale de rn corazon de carnero bien lauado, et tirándole la piel que tiene et nervios et durezas et grosura, et con él dale de la zaragatona, et dende adelante torna á darle tus buenas viandas como primero solia comer. Et si los falcones fueren villanos, como sacres, ó bornys, ó alfaneques, dales los lardones. Pero al nebly non gelos deues dar, et faz mucho por sienpre dar á tu falcon buena vianda, et de pelar, et de plumar, et de tirar á menudo, que cada rez que je tirares el capirote, luego rea el rroedero, ct tire en él, et faciéndole esto, sienpre estará guardado de non renir á auer menester estas purgas, ca so çierto que las purgas desgastan et destruyen el cuerpo del falcon. Pero á la entrada de la muda, ct á la salida, bueno es purgar el caçador su falcon, et quando viere quel viene dolençia, porque se non puede escusar, ca muchas rezes los falcones alcançan rraleas, et céuanse 
en ellas, et comen plumadas, et el ome que non es bien diligente en caiar por su falcon, non cura de esto, et el falcon sobre pone plumas viejas en el buche, que despues enpudrescen ally, et lo traen á que ha menester de ser purgado, é estará en peligro de morir 1 .

1. A. Omite esta frase. 


\section{CAPITULO XIII.}

DEL FALCON QUE DESECA.

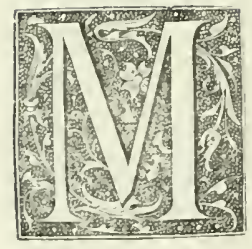

UCHAS vezes acaesce que por malas viandas, et mal pensamiento, et no comer los falcones quando deuen, ó comer poco, ó viandas frias, et non frescas, ó non ser purgados al tienpo que deuen, adolescen, et crésçenles dolençias, et gástanse de cada dia, en guisa que muchas vezes vienen á desecar; et otros falcones desecan desque las filandras ó filomeras son engendradas en el cuerpo. Otrosí, desecan por trópico que han; otrosí, deseca el falcon quando es ferido en el cuerpo, et non es curado como deue, et de cada dia se le gasta el cuerpo, et despues quel falcon comiença á desecar, arnque coma, non le aprouecha nin tiene fuerça en sí, et verlo as triste et apretado, et sacúdese flojo, et non tira nin despluma, et gástasele la carne, et al comienço de esta dolencia lo deues acorrer, ca 
despues avnque quieras non le valdrá; et el rremedio es este. Sy tú vieres quel tu falcon tiene aquellas señales que dize en el capítulo xxvıı I, farás et curarás dél así como manda ally catar, et si tiene las señales del trópigo, segund dize en el capítulo xxxi, que fabla desta dolençia del trópico, curarlo as segund ally manda, et si lo ha de ferida que ouo en el cuerpo, de que non fué bien curado, et la ferida non fué bien 2 apurada, cúralo de la llaga si cerrada non es segund ally manda curar, que es en el capítulo xxxiv ; et si non lo ha destas dolençias sobredichas, entonces tenlo en buen rregimiento, dándole poco á poco buena vianda, et çerçetas, negretas, auiones, si es tienpo dellos, et dale palominos et paloma á degollar, et beua de la sangre, mas non coma de la carne de la paloma, et dale la vianda que le ouieres á dar mojándola en la leche de las cabras; pero non le des grand papo, et dale la suelda que está ordenada en el capítulo xxvi1, que fabla de la pierna quebrada, et non le des pluma nin hueso con que aya de trabajar, et tenlo en buena casa, et dale sol en que piense de sí, et ponlo en el agua si quisiere beuer, et non cures de le mostrar el señuelo, antes faz mucho quanto podieres por lo orgulleçer, et poner en carne fasta que sea recio, como quier que si en tales dolençias luego non mejora, tarde cobra.

1 B. Diez y seteno.

2 A. Falta bien. 


\section{CAPITULO XIV.}

DEL FALCON QUE ES ASOMBRADO.

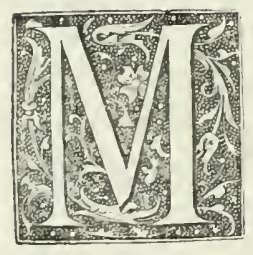

UCHOS omes quieren auer falcones, et caçar con ellos, et non lo saben fazer, et yerran en muchas cosas, señaladamente luego en el comienço, quando el falcon es brauo, et lo comiençan á asegurar, et fazer capirotero. Et ay algunos que toman grand quexa en ello, et cuidando que fazen bien, tíranle el capirote muchas veces et delante las gentes, et el falcon, como está arn brauo, espántase de la gente, et debátese, et non le saben acorrer con el capirote antes que así se derrame, poniendo gelo dulcemente, ó gelo ponen dándole con la mano en el rrostro, et espántanlo más, donde el falcon toma más saña et miedo. Et á las veces quéxase dando sus bozes, et así como vee el rrostro del ome, todauía se más espanta, et cuélgase de la mano, et esto todos los falcones son asaz prestos para 
asíse dañar, señaladamente los girifaltes, et más los torçuelos, otrosí los neblís, así primas como torçuelos. Et quando el caçador que á tal estado lo llegó re así su falcon dañado, enójase dél, et dalo á moços que lo trayan, et todavía se dapnan más fasta que desesperan dél, et déxanlo perder. Et pues esto viene por el mal sufrimiento, et poco tiento del caçador, conuiene que se enmiende con buen tiento, et por todos los contrarios de los yerros que son fechos, et que el caçador torrne á auer buen tiento, mejor de lo que ouo, et mejor sofrimiento, et fará así: cátele rn capirote bien fecho, et bien cerrado, que non rea con él nin le llegue á los ojos, et non gelo tire, saluo quando le ouiere de dar de comer, estonçe se aparte en vna cámara escura, et sin conpaña, é tenga candela, et ally le dé de comer, et que haya grand fanbre, porque con la fanbre oluide la esquiueza et braueza que ha tomado, et non cure sinon de comer, et déxelo alinpiar el pico, et sacodirse, et póngale su capirote muy manso, que non cava de la mano, nin lo dé á moço, nin á ome que faga más yerros con él, et en la noche á la candela déle á tirar, et déle sainetes, et vianda con que tome sabor, et plazer, et póngalo en la noche en su alcándara çerca de su cama, et la candela delante.

Et tómelo antes que el dia renga en la mano, et desque viere que se va asegurando, cátele otro capirote, que vea con él algund poco et deuise las gentes, porque vaya perdiendo el miedo, et así lo leuarás gouernando con buen tiento tantos dias, fasta quel falcon sea asegurado. Et dende adelante, desque lo vieres bien amigo del ome, farás como deues fazer, et si el nebly quisieres fazer, há menester que seas bien sofrido, et eso mismo quieren todas las otras aues, et girifalte et nebly non quieren que los tiren los capirotes, saluo para bolar, ó comer, ó po- 


$$
76
$$

ner en el alcándara, ó poner en alguna agua para lo poner en el prado, segund deximos, lo que non fazen los otros falcones, que lo sufren et van grand pieça sin capirote en la mano. 


\section{CAPITULO XV.}

DEL FALCON QUE HA GÜERMEZES.

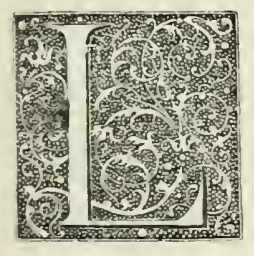

OS güermezes son engendrados en la ca beça del falcon por muchas maneras : los primeros güermezes se engendran en la cabeça quando el falcon es lleno de agua, et aquella agua corre por las narices á la boca, et escaliéntala, et con aquel podrimiento faze los güermeces, et non son de peligro; pero deues lo curar desta guisa. Toma vn paño de lino linpio et mojado en el vino blanco, et láuale la boca con él, et rrocíale con el vino la cabeça et el rrostro, et vsale esto fasta que sea sano. Otros güermeces ay que se engendran en la cabeça del falcon; estos son de feridas de huesos quando comen, et esto fazen los falcones que son garganteros, et trauan de huesos, et lláganse en las bocas, et estos güermezes non son de peligro, et deues los curar con vna paleta muy sotil, desque fueren bien ma- 
duros, que non fagan sangre, et despues ponle de la miel en aquellas llagas, et luego guareçerá. Otros güermezes ay que son engendrados en la boca del falcon, et destos fablaremos et declararemos, porque son más peligrosos que todos los otros. Todos los caçadores conoscen estos güermezes que digo peligrosos; son blancos, et son en figura de granos tan grandes como mijo, et mayores, et son por toda la boca, et por los forados de la lengua, et entran fasta dentro en la garganta, et está en dubda si podrán guaresçer ó non; et deues curar dellos por esta guisa: toma rna paleta sotil de plata, ó de fierro, non sca de caña, que le cortaria, et faria sangre, et tíralos grano á grano, de guisa que non fagan sangre, et toma la piedra alunbre et mućlela, et echa della en aquellos lugares onde tirares los güermezes, et tenlo derribado rna pieça fasta que aquel poluo de la piedra alunbre que echaste faga su obra, que lo non sacuda el falcon, et esto lo faz de tres en tres dias, ó antes si vieres que lo ha menester. Otros güermezes ay que son en las orejas, et estos güermezes non se deuen curar, saluo tirarlos con rna paleta, et fenchirle las orejas de algodon; ct esto le deues fazer dos vezes al dia. Et los más de los falcones que los han traen abierta la boca et non la pueden çerrar, et quando vieres así la boca abierta, luego ten guarda de estos güermezes sobre dichos, et párale mientes en la boca, et en aquel lugar de yuso de la lengua donde las bestias tienen el gallillo, et cata si tienen aquel lugar finchado; et si vieres que lo tienen finchado, toma una lançeta bien aguda, et rónpele á ló luengo bien sin duelo, et si el falcon tiene dentro güermezes, tíragelos et métele dentro del algodon enbuelto con miei. Et sabe que los falcones que esta dolençia han, que non quieren comer, et deues los meter la vianda que sea buena en la 
bova por tuers., porque cuma ca non gete poniendo asi mortia el halion por besmpun. at por esto guede gun-

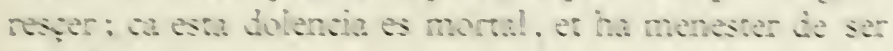
curafa socilmante. 


\section{CAPITULO XVI.}

DEL FALCON QUEL REMANECE EL PAPO.

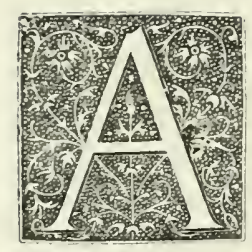

LGUNOS caçadores ay que cuydando que fazen bien et piedat á sus falcones, que les dan muy grandes papos, señaladamente quando toman ó matan alguna presion, teniendo que gelo gradesçen mucho. Et non catan qué vianda les dan, ó qué ora es del dia, si es tarde, en guisa quel falcon non ha espacio nin tienpo para gastar et torçer la vianda et leuarla al buche, ó qué cuerpo ha el falcon, ó cómo gasta lo que come; ca vn falcon tuerçe ó gasta lo que come más ayna que otro, et dándole asy de comer syn razon, otro dia quando amanesçe fíncale grand parte de la vianda en el papo, et finca con vna dureza amasada, et es grand peligro que vienen dende los falcones á se apostemar, et adolescer, et para esto lo primero antes que tu falcon caya en este yerro, guisa de regirlo 
bien, et darle de comer con buen tiento, en manera que bien entienda que antes de la media noche lo aurá gastado et levado al buche; ca dende adelante ha menester de lo sacar del buche por sus tolleduras, así que en la mañana quando lo tomares, el falcon sea purgado si á caçar ovieres. Pero si acaescier tal yerro, que esto non sea guardado, et le remanesçe papo por esta sobejanía de comer, segund dicho es, ponlo ese dia en vna casa muy oscura, que paresca que es de noche, et déxalo y todo el dia en su . alcándara, et ese dia avnque lo gaste non coma ninguna cosa, saluo en la noche juntas de plumas, otro dia luego dále el açúcar cande poniéndogelo en la boca, et ponlo al sol fasta que non tuelga del açúcar quel diste, et pruévale el agua en ayunas, et despues dale de vn corazon de carnero, tirándole la tela et grosura et neruio et dureza, et lauándolo con el agua, et dale en el corazon de la zaragotona; et si vieres que el falcon fincó muy enojado, dale las píldoras del azéuar pátigo, segund diximos en el capítulo xI, que sean fechas como las de azéuar çecotrí, que es en el capítulo $\mathrm{xI}$, et dende adelante guárdate de tal yerro. Et si acaesze algunas vezes quel falcon por non estar sano non gusta la vianda, et remaneçe con el papo, estonçe coge tu falcon, et muy sotilmente con los dedos sácagelo del papo, ó faz gelo regitar, et dale vna gargantada de vino blanco, si lo touieres, si non sea bermejo, et despues déxalo así ese dia fasta en la noche, et entonçe dale vna media pierna de polla con los polvos que fallarás ordenados en el capítulo xxxir, que fabla del falcon que rregyta, quantía de dos garuanços. 


\section{CAPITULO XVII.}

JEL FALCON QUE TIENE EL PAPO LLENO DE VIENTO.

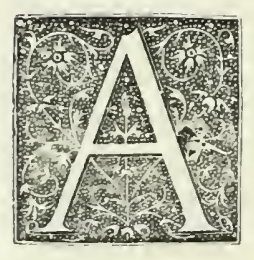

las vezes acaesce que dan los caçadores á sus aues más fauarraz de lo que cunple, et es grand peligro, ca son los vnos falcones más rrezios que otros. De las purgas que dan á falcones esta es muy peligrosa, si non tiene ome en ella tiento, et los falcones que son muy rrezios quando les dan el fauarraz no quieren sacudir, et danlo al papo, et quando así dan al papo, fíncheseles el papo de viento, et por esta rrazon ay falcones á quien esto acaesçe, que traen las tripas llenas de viento, et aquel viento rrecude para ençima en manera de rregueldo, et desque llega al papo detiénese ally, et puesto quel falcon coma et tuella aquel papo non dexa de fenchyr ally viento. Et acaesce á las vezes que quanto el falcon más come tanto se el papo más finche de viento, et los que non saben porque se faze 


\section{3}

esto marauíllanse ende, et por ende este será el rremedio: quando vieres que tu falcon há esta dolençia, et tiene aquel viento farás así : toma el palomo ó paloma biuo, et dalle dello, et coma, et tire, et trague todas las plumas que leuar podiere, et fínchele bien el papo desto, et esto le faz tres ó quatro dias, et luego será el viento fuera, et será el falcon sano. 


\section{CAPITULO XVIII.}

DEL FALCON QUE TIENE PLUMAS VIEJAS.

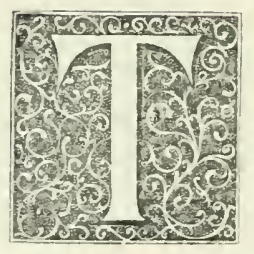

ODOS los falcones que los caçadores han deuen ser guardados que nunca les den de comer fasta que los caten si fizieron la plumada que les dieron, et para esto déuclo poner en vna alcándara, et mandar barrer de yuso en manera que esté linpio el suclo, que quando el falcon fiziere la plumada, que otro dia la fallen, et non se pueda esconder en ningund lugar. Pero guardando esto, que si la plumada non fizicre el falcon, non le den de comer, nin sea lançado á presion nin á señuelo, mas dénle por la boca metiéndogelas vna piedra guija, ó dos tan grandes como garuanços, et si la fiziere con la plumada, dale de comer, et sy por tanto non la quisiere fazer, fazle fincar así para otro dia sin comer ninguna cosa, ct cata si la fará en la segunda noche, et si la non feziere, dale el tártago 
sin otra detenençia, et muchos caçadores son por esta rrazon en grand culpa, et puesto que non les rrequieren en catarlos las plumadas, si las fazen ó non fazen, arn peor que non dexan de darles de comer sobre las plumadas, et desque son dos ó tres plumadas sobre puestas en el buche del falcon, luego el falcon es tollido de dolençia mortal, et tiene el falcon en el buche mal condesijo, magüer el falcon se sostiene, et non mude el senblante, et esto es por quanto las plumadas non son avn podridas, ó non son llegadas á la tripa por do va la materia del buche á las tripas; et quando las plumadas son podridas et llegadas á la tripa sobre dicha, luego el falcon non puede comer toda su vianda como solia, et faze mal senblante, et fiédele la boca, et estonçe, quando esto vieres, cátale el cuerpo, et el lugar do anda el buche, et fallarás aquel lugar duro, et así puedes conosçer aquella dolençia, et el remedio es este : toma la manteca de las vacas cruda, et métegela por la boca, et si la manteca non fuere fresca, et fuere vieja, que huela como azeda, láuala con tantas aguas que tire el mal olor que huele, et dale de la manteca tanto como rna nuez, poniéndogela en la boca en dos ó tres bocados, et aquel dia non coma otra vianda, et luego otro dia le darás el tártago bien reforçado con más granos que los caçadores le suelen dar, et dale de comer ese dia vna pierna de pollo bien tierna, et otro dia toma la miel bien dura, en terron, et métele della por la boca en manera que vaya al buche, et sea tanta la quantía de la miel como la nuez, et desque saliere con ella, que reas que non tuelle materia de miel, mas tuelle su materia como deue propia, toma vn corazon de carnero, et tírale rna piel delgada que tiene, et las venas et la grosura et durezas, et fiéndelo, et tírale los neruios et durezas que tiene dentro, et láualo 
bien con muchas aguas, et desque fuer bien lauado tuérçelo de aquella agua, et toma el azaragatona, et moja aquella carne en ello, et da de comer al falcon delio, et despues bien en la tarde dale de comer de vna pierna de pollo, et verás toller al falcon con vnas tolleduras negras, como pez, et en estas viandas, la miel et zaragatona et piernas de pollo le mantiene fasta que veas que le va mejor, et esto sea tres dias ó quatro, et pruéuale el agua á menudo, et así guarecerá, et en todo aquel año fasta que mude guárdalo de darle plumadas, ca desque los falcones son así entecados, fazen muy mal sus plumadas en todo aquel año fasta que muda. Pero viendo que las há mucho menester, dale plumada fecha de algodon ó de estopa, porque la non podrá fundir. Pero quando el falcon está sano, et le dan sus plumadas, non há tan buena plumada como de plumas, et juntas, ó de pié de ánade, ó de liebre, tiradas las vñas, et quebrantado bien, et con las plumas, et bañado en el agua tibia. 


\section{CAPITULO XIX.}

DEL FALCON QUE TIENE FINCHADO EL BUCHE.

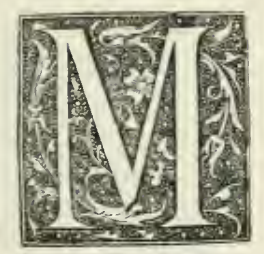

UCHOS caçadores timnen et creen que las aues non son bien pensadas si non son fartas de vianda fasta que más non quieren, et avn algunos que les dan de comer dos vezes al dia, así que deste comer mucho todo el dia fínchale el buche et las tripas de materia, et sobrepónese dentro en tal figura quel falcon non há sabor de comer, et digo que lo verás toller las tolleduras gruesas, et ally donde ha de venir la materia negra entre la blanca, vienen vnos cagadillos que parescen de mures, et el falcon tuelle de tarde en tarde, et deste finchamiento deues lo purgar por esta guisa. Toma el açúcar cande, et métele dello por la boca, et sea quebrantado et menudo, porque mejor vaya al buche, et desque vieres que tuelle del açúcar, sienpre lo ten al sol fasta que venga á toller de su materia pro- 
pia como solia, et pruévale el agua ese dia en ayuno, et beua della quanto quisiere, et despues dale de comer en ese dia del corazon del carnero con la zaragatona, de la guisa que diximos en el capítulo xvir, de las plumadas viejas, et dende adelante farás nueue pílloras de azéuar çecotrí, et el pátigo es bueno para el cuerpo, et el otro es bueno para la cabeça, et deste azéuar pátigo que dicho hé le farás las sobre dichas nueue píldoras fechas et dadas por la guisa que dicho hé et declarado en el capítulo XI, que fabla del agua vedriada, et en quanto le dieres estas píldoras et purgas al falcon, non le des de comer, saluo un mienbro de polla al dia, saluo si fuer falcon girifalte ó açor, que deue más comer el terçio, et así ménos á las otras aues que son menores que estas sobredichas, et dende adelante te guarda que sienpre le des de comer á tu aue por regla, et antes sea el comer poco que mucho, ca del comer mucho les viene este mal et otros muchos, et de comer tenprado nunca les puede venir dapno, et andan sanos. 


\section{CAPITULO XX.}

DEL FALCON QUE HÁ LOMBRICES.

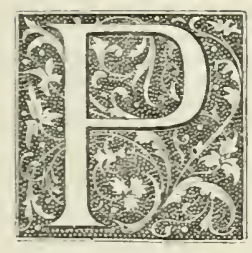

OR mengua de las purgas que non son fechas á los falcones quando les cunplen, se engendran las lonbrices en el buche, et que esto sea verdat, á muchos caçadores acaesçió que quando dan el tártago á sus falcones lançen con ello las lonbrices, porque non eran avn biuas, mas eran ya engendradas. Ca si ellas biuas fuesen, aquella hora non las mataria el tártago, mas mortificarla hya por algunos dias, et de otra guisa non; et avn digo más, que este mismo tártago quando lo dan los caçadores echan los falcones por de yuso la semiente de las lonbrizes, et digo semiente, porque son así como granos bermejos pequeños de que ellas se engendran, et desque son engendradas, et biuas, el falcon que las há mésase en el cuero, et en las pospiernas, et en el papo. Pero muchas rezes non fazen nin 


\section{0}

muestran los falcones estas señales et tienen las lonbrizes, et tú cata las tolleduras sienpre á tu falcon á menudo, et si las ha biuas luego verás algunas dellas bermejas, como gusanillos, en las tolleduras, et si biuas non son non las echan, saluo con la premia del tártago, como dicho es, et estas lonbrizes se pagan de vianda gruesa et dulce, et por ende se deuen curar desta guisa: toma el açafran et mételo dentro en vn corazon de gallina, et dágelo á comer, et desque entendieres que será ya desmolido, toma la semiente de la yerua lonbriguera, et dágela en otro corazon, ó en otra carne de gallina tan grande en que la yerua se pueda esconder. Et si esto non touicres, toma la leche de las cabras, et buelue con ella el çumo de la rrayz del condeso, et en fin deste libro fallarás qué cosa es el condeso, et mételo en vna tripa de gallina, et métegelo por fuerça; otrosí, le darás las píldoras del açéuar pátigo de la guisa que dixe en el capítulo xix, del finchamiento del buche, et que deuen ser fechas como las píldoras del azéuar çecotrí, que manda en el capítulo xI, del agua vidriada, et podrás preguntar así, porque dice este que fizo este libro que las lonbrizes se pagan de cosa dulce, et porque gela manda él dar, ca la leche es dulce, et el açafran es dulce, et huele bien, á esto respondo que verdat es, mas la rrazon por qué es esta: quando las aues comen estas cosas dulces, fázelas talantosas I de comer, por tal figura que quando viene otra cosa que amarga cómenla deseando aquella dulçedunbre que comieran, et estas cosas que amargan, qualesquier que así anıarguen, quanto más amargan tanto más ayna matan las lonbrices, ca con el sabor que toman en comer aquellas cosas

I D. Talentosas. E. Tallantosas. 
dulces remuóuense, et la yerua lonbriguera, et las píldoras fallan las mouidas, et salen más de ligero, et así dende adelante nunca pongas luenga en purgar tu aue en los tienpos que le cunple; otrusi, es bueno tomar la leche de las cabras en una cosa linpia, et pónla sobre el fuego sin fumo, et desque fuere caliente toma las yemas de los hueuos, et bátelos, et échalos en la leche, et todavía tráclo con vni cuchara fasta que sea cuajado et fecho como vngentu, et duro vn poco, et tíralo á fuera, et dágelo á comer que non sea muy caliente, et otro dia dale la yerua lonbriguera, segund dicho es, et despues dale las píldoras del azéuar pátigo, como deximos. 


\section{CAPITULO XXI.}

DEL FALCON QUE HÁ FILANDRAS Ó FILOMERAS.

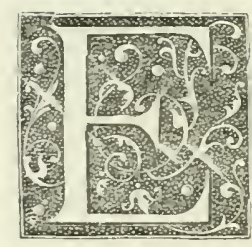

STAS filandras ó filomeras de que agora fabla este capítulo, es vina dolençia de que pocos falcones guaresçen; porque la dolençia es muy graue de entender, et muchos falcones se pierden dello, et porque en punto que ellas son conplidas tan grandes como han de ser, luego comiençan de comer el cuerpo del falcon, conuiene á saber los liuianos, et despues el corazon, et luego el falcon es muerto, ca apenas nunca falcon dende guaresçe. Pero si el caçador quisiere fazer lo que dicho hé en los renglones postrimeros del capítulo del agua vidriada, ally do dize que deuia el caçador reueerse en su falcon como la mujer en el espejo, podria ser que veria en el falcon estas señales que dende se siguen. Digo que quando estas filandras se engendran en el cuerpo del falcon, deues saber que va mucho á me- 


\section{3}

nudo con el pico á los costados et alrrededor de las ancas, et sacúdese mucho á menudo, et quando se sacude aprieta con las manos, et estremécese, et deues saber que entonçe las engendra, et le puedes entonçe acorrer así. Toma las píldoras de açéuar pátigo fechas como las del azéuar çecotrí, segund dize en el capítulo xi, del agua vidriada, que sean nueue píldoras dadas en tres dias por la guisa que dicho auemos en los otros capítulos, et quando gelas metieres por la boca et vieres que las quier regitar, tráuale del pico que las non regite lo más que podieres, de guisa que finque el olor dellas en el buche del falcon, et estas lonbrizes, ó filandras, ó filomeras, non ay otro rremedio; et los falcones pollos están en mayor peligro destas filomeras que desque son mudados, et señaladamente en la muda al derribar de las tijeras, et dende fasta que son desaynados, et por tanto precian más en francia et en alemania los caçadores los falcones desque son mudados, porque están más seguros desta dolencia. Pero oy dezir al visconde dilla, que es rn gran señor en el regno de aragon, et es muy caçador, et muy sabidor de las curas et dolençias de las aues, que cosa del mundo que más guarda el falcon de criar filandras, es vsar de fazer beuer la sangre de la gallina, et quando tu falcon estouiere sano, vsale dar á degollar algunas vezes, siquier tres dias en la semana, la gallina en el señuelo, como diximos en las reglas del nebly en el capítulo viri. Et darle las píldoras del açéuar pátigo, como dicho auemos, á tienpos ciertos, señaladamente al pollo. 


\title{
CAPITULO XXII.
}

\author{
DEL FALCON QUE TIENE PIEDRA.
}

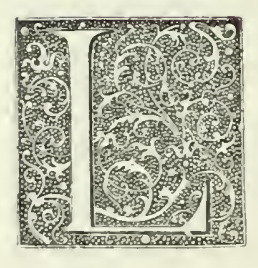

OS falcones que á menudo suelen comer viandas gruesas et malas engendran piedra, et esta se engendra en la tripa por do el falcon tuelle, et se ayunta con el sieso. Et es piedra fecha como vna que traen los alfayates, con que señalan, que paresce de yeso blanco, et esta piedra quando así es engendrada, puedes lo entender por esta guisa: quando vieres quel falcon tuelle vna vez luego, et luego tuelle en pos della, et despues desto va con el pico al ouero, et se le ensuzia, et demás bate á menudo con la boca en la lua, et vnta las péñolas del ouero con suziedades, sabe que entonces há piedra, et deues le curar por esta guisa: toma la semiente del perexil, et dágela á comer en la carne 


\section{5}

de la gallina ó en vn coraçon de gallina, et está aparejada la materia, et otro dia métele la miel terron I dura por la boca fasta que vaya al vientre quantía de vna nuez en tres ó quatro pedaços, et desque vieres que la miel faze su obra por la guisa que ya dixe en el capítulo xvin, de las plumadas viejas, que la há tollida todo el falcon, et torna á toller de la materia que suele, entonçes dale el coraçon del carnero con la zaragatona, así linpiado por la guisa que dixe en el dicho capítulo de las plumadas viejas, et despues en otros dias siguientes toma la mil sande 2 , et en la fin del libro fallarás qué yerua es, et muélela, et dale el poluo della en la carne; otrosí la llamada mira solis, que son cañamones montesinos, et tiénenlos los buticarios.

Et si non podieres auer la mili sanda, toma la yerua que dizen capil ueneris 3 , otrosí la llaman culantro de pozo, seco et poluo fecho, et dágelo desta guisa. Et si vieres que esta piedra es tan grande que la non puede lançar, para mientes al falcon, et verás que quiere toller et non puede, entonce sabe que la tiene en lo baxo, et la non puede lançar, et entonçe derriba el falcon, et láuale bien el sieso con agua tibia, et apálpale en aquel lugar, et si gela fallares prémegela mansamente como quando prime la furonera al furon, et así gela farás salir, et despues luego en ese dia le darás la miel et el corazon del carnero con la zaragatona, segund dicho es, et non enbargante que otros caçadores dizen que ay otra piedra, non lo creas, ca el falcon non

\footnotetext{
A. Dentro.

2 F. Miel sana. G. Miel saña.

3 Utros Ms. dicen tapal véneris.
} 


$$
96
$$

há lugar otro en que la engendre, et todas las criaturas que piedra engendran, non la engendran, saluo en la vexiga, et el falcon non há otra vexiga en que la engendre, saluo en esta tripa susodicha. 


\section{CAPITULO XXIII.}

DE LA FísTOLA QUE SE FAZE EN LA LLAGA DEL FALCON.

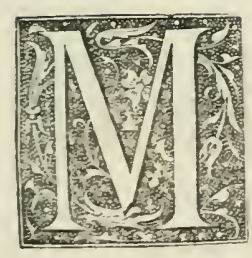

UCHAS ocasiones acaescen á las aues por muchas maneras et desuariadas, así de ferịdas de garças, como de gruas, como de árboles por do los falcones entran quando buelan, et vienen á golpar, et por otras maneras, et quando son feridos et no son curados con diligencia qual deuen, vienen las llagas á fistolarse, et digo que esta dolencia sienpre se llaga en las coyunturas de los huesos et neruios, et si vieres que la llaga está ya en que la fístola es sobrepuesta, et non se quiere guareçer por melezinas que le fagan, entonçe á esta dolençia deues acorrer por esta guisa. Toma los fierros que son figurados en el agua vedriada, en su capítulo, et caliéntalos bien señaladamente de la parte de los botones, et pon los dichos fierros bien calientes en aquellos lugares do está la fístola engendrada so- 


\begin{abstract}
98
tilmente, et si vieres quel lugar há menester verga de fierro, que la carne está sobeja et non se puede traspasar con los botones, toma otros fierros fechos por esta guisa que aquí están figurados para cortar la carne sobeja que deximos, desta parte los pon del agudo.
\end{abstract}

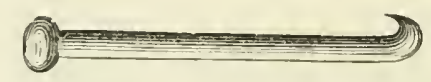

Et vnta aquel lugar desque fuer labrado con azeyte tres dias, et toma vna yerua que dizen encenço i et faz della poluo bien sotil ó un poco de cardenillo, et sabe que aquel lugar fará la postilla muy gruesa, et desque vieres que la postilla es bien madura, tíragela et lánçale aquel poluo cada dia dos vezes al dia, segund que vieres que la postilla se quiere mouer, et así sanará.

I R. Enxunta. D. Ayxonqua. E. Excotma. 


\section{CAPITULO XXIV.}

DE LA COMEZON QUE TIENE EL FALCON EN LAS PLUMAS QUE SE LAS COME ET SE I.AS TIRA.

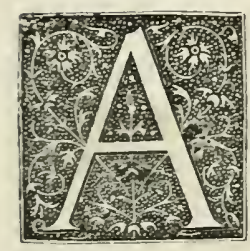

CAESCE á las vegadas quel falcon há comezon en los lugares en que nasçen las péñolas, et esta comezon non es engendrada de otra cosa, saluo de pujamiento de sangre, et esto paresçe de buena razon que así es, ca quando los falcones están en tienpo que derriban las péñolas et vienen las nueuas, todo el cuerpo del falcon está dolorido et metido en sangre nueua, et por fuerça conviene que todas las cosas engendradas que de nueuo I meten, non tan solamente de las aues, mas de todas las otras criaturas quando así meten de nueuo, todas han esta comezon, ca cada vna destas criaturas conviene que se refregue et se rrasque en alguna cosa; por ende digo que esta comezon que viene así á estos falcones es por la dicha razon, et

1 En A falta que de nuevo. 
digo questas aues sobredichas conviene que vayan con el pico á aquel lugar, et quando aquella comezon es abiuada, aprieta con el pico en aquel lugar fasta que faze salir sangre, et dende adelante ençiéndese cada dia esta comezon, así que las péñolas del falcon peresçen et van á mal, et porque cada vez que la sangre se seca en aquel logar et por las otras péñolas por la comezon que ally es, et el enojo que la sangre le faz que se seca este quajo en las otras péñolas, conviene que padescan las otras péñolas en que non há comezon, et porque la aue non es criatura que aya rrazon de se poder guardar por sí, nin poder auer sangrías, como su cuerpo non sea dispuesto por la guisa de las otras criaturas susodichas que aquella comezon han, conviene catar rremedio para ello, et digo mas, que si vieren que los falcones tirasen las péñolas viejas en el tienpo del ynuierno quando las aues non mudan, diria que las razones suso dichas non eran conuenibles nin rrazonables nin verdaderas, mas non fazen esto si non al tienpo de la muda, quando la sangre puja et se desnuda el falcon de las plumas viejas et traye las nueuas, et á esta comezon deuemos acorrer en esta guisa. Toma el azéuar çecotrí et muélelo, et amásalo con la miel, et ponlo en aqueñas péñolas do se el falcon come, et úntalas bien sin duelo, et tráelo á menudo en la mano; et así lo podrás guarecer desta dolencia, ca este azéuar le fará aborreçer que non vaya con el pico á la péñola por la su amargura, et la miel póngela porque pegue con ella en las plumas, et el traerlo en la mano es por non le dar vagar que mucho á menudo lo faga ; otrosí, por lo requerir que esté sienpre vntado de aquella melezina en las péñolas, ct esto le faz cada que vieres que aquella melezina se derrite de aquel lugar, de guisa que sienpre tenga ally la melezina. 


\section{CAPITULO XXV.}

DEL FALCON QUE SE LE TIRA LA VÑA.

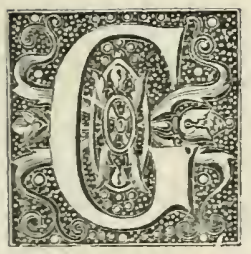

RAND bien es al caçador et gran bondat ser sufrido á su aue, et esto es por muchas razones: la primera, por quel falcon no le tome miedo del rrostro; la segunda, porque le non quebrante las péñolas, et por muchas otras ocasiones que á las vezes acaescen por el caçador sañudo, et acaesçe que ay falcones que son caninos al comer, et quando el caçador quiere desenpulgar su aue, con quexa que toma sácale la vña, et eso mesmo acaesçe quando toma alguna presion et lo saca della sin buen tiento, et por muchas otras buenas razones conteçe á las vezes esta ocasion, et si vieres que la vña quiere salir del dedo del falcon et está avn trauada en aquel lugar que non es del todo arrinca$\mathrm{da}$, derríbalo luego et córtale la dicha vña con unas turquesas fasta que llegues á lo biuo, et toma suelda et la 
102

sangre del drago et el bolar menique, et el azéuar çecotrí, et muélelo todo bien, et échale de aquel poluo et átale la vña ençima del dedo, et sea enbuelta con vn paño de lino muy delgado, et fuelgue por espacio de tres ó quatro dias, et guárdalo que non sea lançado fasta nueve dias, et si la vña fuer arrincada del todo, toma los dichos poluos et cúbrele bien el maçlo, et toma el más delgado cuero de baldrés que fallares, et cúbrele el mazlo con él, et cósegelo ally fasta ençima de la cabeça del dedo, de guisa que se le non desate, et de seys dias adelante non dexes de yr á caçar con él; et guárdalo al desenpulgar non le fagas enojo en guisa que non desuelde lo que está soldado; otrosí ay que gelo cubren en lugar de baldrés con la pelezilla de vna piel de vna aue, et pégase mejor. 


\section{CAPITULO XXVI.}

DEL FALCON QUE HÁ Clavos EN LOS PIÉS.

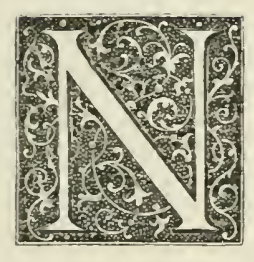

ON enbárganse que todos los falcones han á las vegadas clauos en los piés, pero los girifaltes son los falcones de quantos son que más han esta dolençia, et son más naturales della; ca son de su conplision muy calientes et muy pesados et cargados, et por ende han esta dolencia de los clauos, et fínchanseles los piés más que á otros falcones de qualquier otro plumaje. Pero los falcones alfaneques son eso mismo muy naturales desta dolençia, et son de su natura calientes, et quando el falcon há esta dolençia, há dolor en los piés, et dexa mucho de fazer de lo que deue, por el gran dolor que há, et conuiene á esto de poner el mejor rremedio que podiere ser, ca ha de ser fecha en esta dolençia la cura muy sotil, ca el logar onde viene, que es en los piés, es logar neruyoso et pobre de gouierno, et es 
104

lugar peligroso, porque todo el cuerpo se sostiene sobre los piés. Et estos clauos por descendimiento de escalentamiento fázense en las suelas de los dichos piés postillas tan grandes como cabeças de clauos pequeños, et por esto son llamados clauos, et luego que estas postillas ally son en los piés, son finchados los piés, et quando vieres que los piés son finchados, toma las turquesas del menester de los falcones, et córtale todas las vĩas, de guisa que todas lançen sangre, et toma la trementina et xabon francés, et çeniza de sarmientos, et la trementina será lo de más, et el xabon tanto como la meytad de la trementina, et la çenisa tanto como la meytad del xabon, et sea bien cernida, et échalo todo en vna olla pequeña nueua, et fazlo feruir bien sobre brasas, et mécelo sienpre con vn palo de guisa que todo sea bien mezclado, et desque vieres que es bien cocido, arriédralo á fuera, de guisa que se non queme, et déxalo esfriar de todo punto, et faze como vnguento et rrezio como betumen, et toma vna paleta rrezia de fierro ó de laton, et toma de aquella melezina, et pónla sobre vn cuero de baldrés delgado, fecho por esta guisa.

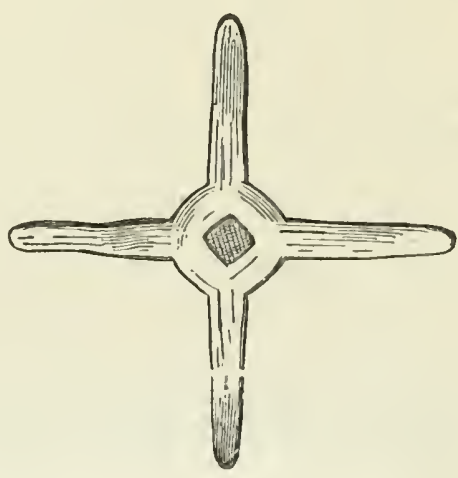


Et entre estos quatro rramales que tiene sea puesto en aquel espaçio el vn dedo del falcon, et así los otros dedos entre dos rramales cada vno, et la melezina susodicha sea puesta delgada en el espaçio en medio del cuero entre los quatro rramales, et los rramales sean luengos, et sean ligados por sí por esta guisa. Toma los rramales delanteros et lígalos tras el çanco, et los rramales çagueros delante contra la planta del pié, en crus, et déxalo estar así tres dias, et á los tres dias tírale aquel cuero sobredicho. Et para mientes si vieres que creçe á derredor aquella postilla como sostra debestia, atiéntalos si quisieren salir de rrayz, et si vieres que se detiene et non se quiere arrincar, pónle la dicha melezina otros tres dias fresca, et al cabo de los tres dias saldrán los clauos, et desque fueren salidos, si vieres que finca dentro en aquella cueua donde salió el clauo alguna carne podrida, lánçale del cardenillo molido, et pónle la sobredicha melezina otros tres dias sobre el cardenillo ligada por la guisa que dicha es. Et sea cada dia aquel vnguento con la sobredicha melezina tirado et linpio, et puesto en aquel pié del falcon, et despues que fueren los clauos fuera, por alinpiar la materia que fiziere la llaga que ally se fizo, et desque vieres que aquella cueua es llena de carne nueua, pónle diaquillon que tienen los çerugianos, por la guisa de suso dicha en otro á tal cuero, como el que de suso deximos. Et desque vieres que es bien curado $\mathrm{r}$, toma el aziche et la casca de la enzina et escoria et çumaque, tanto de lo vno como de lo otro, et muélelo bien cada vno sobre sí, et desque fuer bien molido, açérnelo bien, et échalo todo en vna olla pequeña nueua, et fínchela de vinagre lo más

I C. Encorado. 


\section{6}

fuerte que podieres fallar, et fazlo todo feruir bien, meçiéndolo todauía, et desque fuer cozido tíralo á fuera; et quando fuere tibio, toma vn paño de lino tan grande en que quepan los piés del falcon, et mójalo en aquel caldo, et pon el paño doblado de quatro dobles ençima de vna piedra redonda como alcándara, en que se pueda bien tener, ó en la vara do suele estar, porque si la piedra estouiere baxa, non sosiega tan bien el falcon, et de sy pon el falcon ençima, de guisa que tenga los piés ençima de aquel paño, et esto sea por espaçio de medio dia, et esto lo farás cada dia fasta que veas quel cuero es bien tiesto en los piés del falcon. Et dende adelante lo trae en la buena lua muelle et blanda de cuero et non de paño, porque es caliente, et sea de cuero blando, et algund poco gruesa, porque la calentura de la mano non pase á los piés del falcon, et guarda que quando feziere sol, si sintieres que se le escalientan los piés, luego lo pon en vna piedra fria, et la lua so los piés, ansí esté en la alcándara, et en esta cura lo mantiene fasta que sca sano. 


\section{CAPITULO XXVII.}

DEL FALCON QUE SE LE FINCHAN LOS PIÉS Ó LE ARDEN.

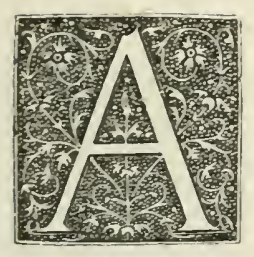

CAESÇE á los falcones que se les finchan los piés et le arden por desuariadas razones: la vna por las malas piuelas, et apretadas, et de mal cuero; et demás si el falcon es quexoso, et esto es por mengua del señor del falcon, ó del sufalconero, si el señor gelo dexa en su guarda, asy como del rrey ó de grandes señores que tienen carga de curar et de requerir sus aues; et si el falcon por esta rrazon de las piuelas tiene los piés finchados, tíragelas et pónle vnas piuelas de lienço, et tájale las vñas fasta que sangre dellas salga, et toma la grosura de la garça, et el aluayalde blanco que ponen las mujeres, amasado todo en vno, et úntale los piés dos ó tres vezes al dia, et así.guaresçerá. Otra finchazon viene á los piés del falcon en manera de gota, et quando vieres que al tu falcon finchan 
los piés, et non lo há de las malas piuelas, fazle cortar las vñas todas á rrayz del mazlo, de guisa que salga sangre de todas ellas, et de sí toma vn vnguento que llaman dialtea que tienen los çerugianos, et vntale con ello los piés dos ó tres vezes al dia, et fazle buenas piuelas de lienço, segund dicho es. Et si vieres que por ençima desta finchazon se leuantan vnos torondos tan grandes como garuanços, non cures dellos, ca ellos se tornarán en piedras, et vernan fuera á su término, porque las podrás sacar con vna lançeta, et estos non le enpesçen al falcon fasta su términe, faziéndole estas vnturas de la dialtea. Et si vieres que esta finchazon non ablanda con estas cosas suso dichas, et cada vez finchan más los piés del falcon, et se paran como luzios, toma los fierros figurados en el capítulo $\mathrm{x} 1$, que fabla del agua vidriada, et mételos en el fuego de parte de los botones, et desque fueren bien calientes dale entre los dedos cada sendos botones, et sea el boton tan grueso como vn grano de pimienta, et úntagelos fasta nueve dias con aceyte tibio, et dende adelante úntagelos con vn vnguento que llaman çetrino ó amarillo, que tienen los cerujanos, et luego será sano. Et si vieres que non le finchan los piés, mas que le arden, córtale las vñas de los piés como dicho es, fasta que le salga bien de la sangre, et vntale los piés con el meollo de la carrellada del toçino añejo cada dia, ó con la enxundia de la garça et el aluayalde amasado en vno, é luego guarecerá. 


\section{CAPITULO XXVIII.}

DEL FAlCoN QUE SE LE QUIEBRA LA PIERNA.

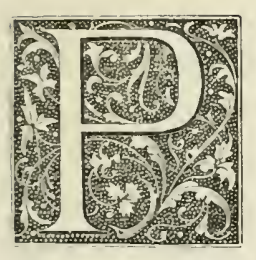

OR muchas guisas vienen á los falcones grandes ocasiones, que ningund ome non lo podria creer si caçador non fuese que lo oviere fecho é visto, et lo oyese dezir que vn falcon máte de un golpe vna garça ó vna liebre ó lauanco; pero esto acaesçe cada dia, matar vn falcon vna liebre de un golpe, de guisa que luego queda muerta sin otro can, et eso mismo á la garça muchos cazadores la veen matar de vn golpe, quebrantándole el pescueço. Et eso mismo muchas vezes el falcon bolando en la rribera quando buela baxo encuentra et líjase, quebrantándose ala ó pierna; ó por venir golpar en seco á pequeñas aues, así como á çerçetas, et por tales valentias et ocasiones como estas et golpes que los falcones así ponen en aquellas presiones, 
acaésçeles que ellos mismos se quiebran las piernas por las cuxas et por los çancos. Et quando esto acaesçe, déveles acorrer por esta guisa. Toma ençienso et alrnástica et sangre de drago et piedra sanguínea, tanto vno como otro, et muele bien cada vno sobre sí, et çiérnelo et mézclalo con vn poco de farina de trigo bien çernida, que non sea mas que la quarta parte de los poluos, et toma la clara del huero, et bátela mucho fasta que le tires toda espuma, et desí toma los poluos sobredichos mezclados con la farina, et amásalos con la clara del hueuo, et derriba el falcon, et si la pierna fuer quebrada por la cuxa, trasquílale las plumas con vnas tijeras muy agudas, et toma de las cañas del carrizo, et faz dellas sus cañuelas bien fechas que puedan tomar bien la pierna; et cata que en la llaga non finque pluma alguna escondida, et úntale bien la pierna con aquel vnguento, et póngelo en manera de enplasto, et cúbregelo ençima de estopas de seda bien blandas et sin nudos, et despues otra tela de enplasto sobre las estopas, et despues las cañuelas sobre el enplasto, et sean puestas en conpás vna de otra en derredor de la pierna. Toma rn paño luengo de lino tan ancho como fueren las cañas, et enbuélvelo muchas vezes por encima de las cañas, et aprétalo por la guisa que vieres que cunple, et desque fuere así ligado, cose el paño con buen filo de guisa que se non desate, et esto fecho, dale de comer de la suelda en un corazon de gallina, tanto de la suelda como vn grano de garuanço. Et si lo non quisiere comer, métegelo por la boca. Et la suelda se faze de aquesta guisa, et es muy noble et preciosa para todas las quebrantaduras dentro del cuerpo: toma la momia que tienen los buticarios, et la pez et la zaragatona et la semiente de la yerua menudilla que llaman suelda menor, et semiente de mestuerço et suelda 


\section{1 I}

raca $\mathrm{I}$, et de la momia sea la mayor parte, et de suelda menudilla la quarta parte, et de la semiente del mastuerço la ochaua parte, et de la zaragatona toma la quarta parte, et de suelda raca ochaua parte, todo esto á rrespeto de la momia. Et todas estas cosas sean molidas et çernidas por su cabo, et despues sean mezcladas et bueltas en vno, et faz vn saquete pequeño de baldrés, et mete dentro aquellos poluos, et si feziere sol seco pon aquel saquite al sol et caliéntalo bien con las manos, et si non feziere sol, mételo en tu seno á cerca de la carne. Esto se entiende que se faz por virtud de los poluos que se ayan de mezclar et ayuntar vnos con otros, et deuedes todos aquellos que los falcones amades esta suelda sienpre traer con vusco, ca es muy noble, et desque el falcon ouicre comido de esta suelda, pónlo en vna tabla ancha et llana como mesa, et su paja de yuso, en que se pueda echar si quisiere, et deue estar ally veintiun dias, et en estos sobredichos dias le darás la dicha suelda de tres en tres dias en el coraçon de vna gallina, quantía de vn garuanço. Et en estos sobredichos dias non coma si non buena vianda, así como pollas et gallinas, ó palominos ó tórtolas, et sea la vianda que le dieres picada en vna tabla, de guisa que non ponga fuerça para estribar sobre la pierna; et á cabo de veintiun dias descósele aquella atadura, et dale de comer en la mano fasta que veas que es bien esforçado, et de dia ponle en el alcándara, et de noche tórnalo á la tabla do primero estaua, et así esté en este gouernamiento fasta que veas que es bien esforçado, et así guareçerá; et si la pierna es quebrada por el çanco, desta guisa que dicha hé en este capítulo curarás dél, saluo que le deues tirar la piuela et el cascauel.

I D. Roca. 


\title{
CAPITULO XXIX.
}

\author{
del FAlcon Que SE lE QUiebra el ala.
}

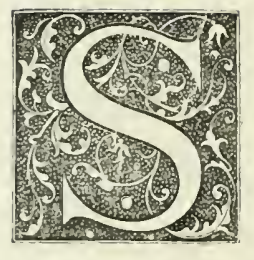

EGUND dicho hé en el capítulo antes de este en rrazon de las ocasiones porque guisa vienen á las aues, et así digo que eso mismo conteçe á las vezes que algunos falcones toman algunas rraleas, así como garçotas et martinetes ó garças, que son rraleas que van á la tira, et á otras rraleas que los falcones fallan en su cabo quando andan alongados de los falconeros, así como cornejas et dorales et otras, et tómalas entre puercos et buyes et otras bestias; et acaesçe que las sobredichas bestias quando veen el falcon en su cabo sin ome vienen á él et fiérenlo, et líjanlo estando enbuelto con su rralea que ha tomado, así que le quebrantan á las vezes la pierna ó el ala. Et quando tal ocasion acaesçe al falcon deucdes curar dél por esta guisa : si acaesçiere que se le quiebra el ala, trasquílale 


\section{I1 3}

aquel logar de dentro et de fuera con vnas tijeras muy agudas, et non gelas arranques, et despues eguálale bien las plumas del ala quebrada, et pónle el enplasto de que suso dicho hé en el capítulo que fabla de la pierna quebrada, et por aquella misma guisa, et cañuelas; mas á la atadura farás por esta guisa: toma vn paño de lino delgado que aya seydo lauado porque sea más blanco, et sea tan ancho como las cañas del ala, et sea luengo, et átalo bien, et cose despues el atadura muy bien con el, filo, et desque fuer bien cosido, toma otra vez el aguja, et vn filo, et cose el ala, et çiérragela como quando el falcon está sano, et llégagela bien al cuerpo, et cósele todos los cuchillos pasándogelos todos con vna aguja quadrada por los cañones con vn filo que se le non pueda arredrar, et toma vn paño de lino, et enbuéluele en él toda el ala así çerrada et cosida et cogida, como dicho hé, et cose aquel paño de lino como viene cosido el falcon quando lo traen de flandes, que traye de la meytad del ala ayuso contra las puntas de las péñolas enbuelto con vn paño de lino; et faze en el sobredicho paño de lino dos rramales, et vn rramal vaya por detrás del ala sana contra la cola, et el otro rramal contra la cabeça, et ayúntense amos los rramales so la ala sana, et sean bien cosidos ally, et vayan por el pecho, et cósase en el paño que fuere enbuelto con el cobdillo del ala. Et estos rramales sean cosidos amos sobre las cuestas fasta el onbro del ala sana, et por el pecho fasta el ala llagada, de guisa que se non puede el atadura desatar, ca bien vos digo que esta obra et atadura deue ser fecha muy firme, et llama falconeros de buen tiento que te ayuden á fazer esta obra, et á vn çerujano, porque ese tiene buen tiento en saber las ataduras, et poner el cnplasto, et darle as de tres en tres dias de la suelda que dixe en el capítulo de la pierna 


\section{4}

quebrada, et el falcon que así fuere atado et cosido, deue yazer vn dia todo encamisado, et esto es porque se seque el enplasto. Et desque vieres quel enplasto es apretado et seco, desencamisa el falcon, et ponlo en vna tabla ó mesa llana, en que se eche, et esté como él quisiere, et átalo por la lonja, que non se parta de ally, et no lo descosas fasta veynte et vn dias. Et en el comer et en los otros regimientos goviérnalo segund deximos en el capítulo de la pierna quebrada, et conviene et es forçado que fuelgue fasta que venga la muda, et cobre pénolas, ca non há con qué bolar, et avnque las touiese deue folgar fasta la muda pasada. Et non dubdes que si buena diligençia ouier en lo curar, que guaresçerá, et yo vy vn falcon baharí sardo al rrey don pedro, que traya ruy gonçalez de yliescas, comendador de santiago, su falconero, que se le quebró el ala cayendo con vna grua, et despues fué sano della, et vile despues matar muchas gruas con tan grand auentaja como de primero las mataua. 


\section{CAPITULO XXX.}

DEL FALCON QUE SE LE QUiEbra EL OJO.

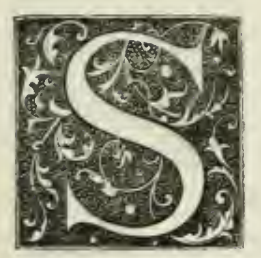

EGUND he dicho en otros capítulos antes deste, muchas ocasiones acaesçen á los falcones, et acaesçe quando los falcones son echados á garça et á otras presiones que los falcones vsan matar, señaladamente los falcones garçeros, quando andan con la garça, ó la traen á tierra, fiéreles la garça con el pico en el ojo et quiébragelo, et si el falcon es perdiguero, ó lebrero, andando con la liebre, ó con la perdiz, topa en algund palo, ó espina, de guisa que se le quiebra el ojo, et aquesta ocasion deuedes acorrer por esta guisa: toma vna yerua que llaman pimpinella, et otros la llaman vursa pastoris, et otros la llaman yerua golondrina, et naçe cabe las paredes, et ticne vna como 
bolsilla en lo alto, así fecha| como esta : et májala, et toma el çumo della bien colado, et toma la terçia parte de miel et coral blanco molido et çernido, et tomarás aquel poluo mezclado con el çumo de la yerua et con la miel, et derribarás el falcon, et toma vna péñola hueca, que se fincha de aquella melezina, et despues con la boca soplando échale aquella melezina que dicha es, et lánçale dél en el ojo

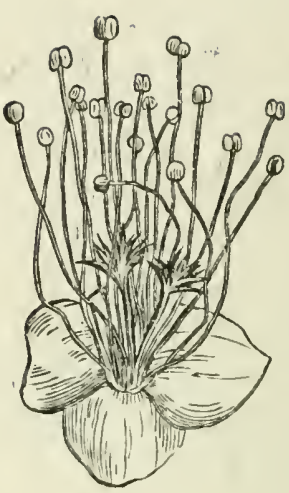
llagado, que le caya dentro, et échala con vna péñola de gallina, en guisa que le caya en el ojo, et ten el falcon derribado fasta que veas que todo el çumo es consumido, et ponle luego el capirote de guisa que lo non pueda sacodir de la cabeça, et esté por tal guisa guardado el falcon que se non rrasque nin pueda llegar con la mano al capirote nin al ojo, et sea puesto en vna cámara escura, et deues saber que si la yema del ojo non fuere ferida, quel falcon cobrará toda su vista, non enbargante que quando la ferida es dada, que todo el ojo es vazio segund paresce, tan fermoso torna el ojo despues como si nunca fuera ferido, et si la lunbre del ojo fuere ferida, nunca cobrará la vista, mas cobrará la fermosura; así que pocos omes conoscan si el falcon es çiego del ojo ó non. Et esta melezina deues fazer dos vezes al dia fasta que veas quel ojo es tornado en su fermosura, et si le fincare nuue ó paño, échale el poluo del coral blanco bien çernido, et así guareçerá. 


\section{CAPITULO XXXI.}

DEL FALCON QUE Ha TRÓPIGO Ó FINCHAZON EN EL VIENTRE.

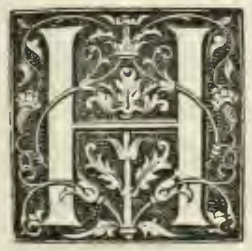

$\mathrm{AN}$ vna dolencia los falcones que es llamada trópigo, et esta dolençia se engendra en el vientre del falcon. Desta dolençia señaladamente son naturales mucho los girifaltes, que son aues muy pesadas et muy afogadizas et antojadizas et quexosas por natura. Et señaladamente quando dexan á qualquier falcon en el alcándara, et se debate mucho, ó en la muda, que non es bien guardada, et el falcon se espanta et se debate; et con grand quexa acaesçe á las vezes que se corronpen en el cuerpo por tal guisa, que se los faze en el vientre vna vexiga, et fíncheseles de agua, et es aquella agua de aquella vexiga, et está metida en el buche et los fígados et las tripas, et esta agua que digo que ally está escaliéntase por tal guisa, quel buche et las tripas et el figado cueze por tal guisa 
ct por tal figura, quel falcon viene á la muerte, et tú deues conosçer esta dolençia por esta guisa: sabe que quando el falcon há esta dolençia, que deseca, et non dexa por eso de comer, et fínchasele el vientre por tal guisa, que paresçe que trae rn grand huevo; et tiene las cuxas de las piernas como gastadas et secas, et non puede bolar, et quando tuelle faze malas tolleduras et desuariadas et feas. Esta dolençia es mortal, pero deues curar della, et non desanparar el tu falcon, et el rremedio para esta dolençia es este : derriba el falcon que esta dolençia ovicre, et envuélvelo bien atados los piés con la lonja, et échalo de cuesta, et trasquílale todo el vientre non le llegando al pecho, con vnas tijeras muy agudas, et desque fuere trasquilado toma vna lançeta muy aguda, et fiéndele el vientre á luengo, et cata que tajes el cuero et non llegues á las tripas, et comiénçalo en el pico del pecho do se acaba el obero, et la abertura sea tan grande que aya tres puntos, et entre punto et punto aya espaçio de vn medio dedo, et desque fuer fendido buelue el falcon el vientre ayuso, et los costados arriba, et saldrá aquella agua dél. Et desque vieres que aquella agua es fuera, buelue el vientre del falcon arriba, et cóselo, et dale aquellos tres puntos, et llama çerujano que lo faga, porque há buen tiento et tiene vso dello, et mata vna gallina et échale la sangre della por ençima de la costura. Et la razon por qué se faze esto de la sangre, es esta: porque conuiene que el lugar do ha de auer suelda de fuera aya sangre, porque la suelda pegue mejor, et porque aquel logar non es tal que faga sangre de suyo, por ende es menester ponerle aquella sangre de la gallina. Et desque aquella sangre de la gallina fuere puesta sobre aquellos puntos de la costura, échale la suelda por encima de la sangre, et esta suelda sea fecha por la guisa 
que dixe en el capitulo xxv, que fabla de quándo el falcon pierde la vña, et despues toma la otra suelda preçiosa que dixe que era buena para el cuerpo en el capítulo xxviı, del falcon que se le quiebra la pierna, et dale della vn grano tan grande como vn garuanço en vn coraçon de gallina, por la guisa que de suso dicho hé, et si lo non quiere comer, métegelo por la boca, et todo este dia yaga $\mathrm{cl}$ falcon enbuelto en rn paño de lino, encamisado sobre vn cabeçal, el vientre ayuso, et á la noche dale de comer media pierna de gallina picada, que sea tirado della el escudete et lo duro, antes que lo descamises, et si lo non quisiere comer, métegelo por fuerça, et en los nueue dias le da de comer de la suelda en vn corazon de gallina, quantía de vn garuanço á los tres dias, en manera que coma de vna suelda tres á quatro vezes. Et esto todo fecho, desenbuéluelo de aquel paño, et ponlo en vna buena alcándara et vn paño de lana de color enbuelto en derredor de la alcándara, et si non quisiere estar seguro en el alcándara, ponle en vna tabla llana, et pon vn paño de lana blanco ençima de la tabla pegado con clauos, porque esté caliente, et la casa sea bien caliente sin viento et sin fumo, et toma otro dia el alosna, que es ençenso amargo, et cuézelo en vino blanco en vna olla pequeña, et láuale bien cada dia en aquella agua, et dale de la suelda que dize en el capítulo xxviri de tres en tres dias á comer, et non lo saques fuera de casa fasta los nueue dias, nin le des vianda que ouier á comer, saluo picada et caliente et buena, et dende adelante cómala entera por su pico, et non le des plumas. Et sabe que si este acorro fuere fecho á esta dolençia, antes quel fígado et el buétago sea escalfado, luego el falcon será sano, mas si el falcon touier ya el fígado et el buétago escalfado está en dubda si guarecerá ó non, et por tanto es menester de 
ser el caçador auisado en veer su falcon si adolesce segund las señales de las dolençias, et acorrer ayna á tu falcon antes que la dolençia sea vieja, et non aprouechen las melezinas. Esta finchaçon que es entre el cuero et la carne, de que este capítulo fabla, acaesçe así: que quando algunos falcones son lançados á quellas presiones que á menudo suelen ser lançados, como á liebre, ó á grua, ó á perdiz, algund can traua del falcon, et rónpele el cuero, ó puede ser que en la cayda que cae con la garça ó con la grua rónpese el cuero, ó bien puede ser que la garça ó la grua lo fiera, así que por aquel lugar que es así rroto el cuero fínchase todo el falcon ó parte dél de viento, ć paresçe muy feo, et aquel que esto non vió parescele cosa estraña, et espántase dello, et esto es vna cosa muy ligera de curar, et cúrase así : si vieres que non tiene otra llaga, saluo aquel cuero tiene así finchado et leuantado, toma vna lançeta muy aguda, et rrónpele aquellos lugares do el viento así está, et luego saldrá todo el viento, et toma el alosna, que es ençienso amargo, con el vino blanco, et cuézelo en vno, et caldéale bien aquellos lugares que vieres que tiene la finchazon, et tenlo en lugar caliente et sin viento, et luego será sano, et caldéagelo así algunos dias fasta que veas que se tira vn color malo de que el cuero está así señalado. 


\section{CAPITULO XXXII.}

DEL FALCON QUE REGITA ET TIENE EL PAPO ET TRIPAS FRIAS.

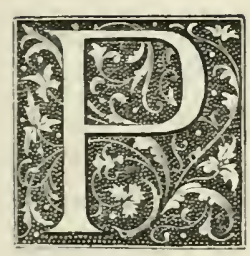

OR muchas cosas entra la frialdad en el papo del falcon et en el buche et en las tripas, lo vno por el tienpo frio et de grand ynuierno, et non comer el falcon, et dormir ayuno, lo cual deue guardar todo caçador que el su falcon duerma sienpre con alguna cosa en el papo, ó vianda, ó plumas; otrosí se rresfria el falcon por comer mala vianda et fria, señaladamente en el ynuierno; otrosí, por andar con él á caçar en tienpo lluuioso, et venir el falcon mojado, et non ser enxuto al sol ó al fuego sin fumo et de lexos, ca si el falcon viene muy mojado et non ha sol para se enxugar, faz traer á la cámara de la brasa sin fumo, et dándole á tirar et rroer çerca del ayre del fuego, se yrá enxugando, et despues ponlo en buena casa caliente et que tenga toda la noche candela ardiendo, por- 
que piense de sí, et otro dia non le fagas bolar por presion fasta que se enxugue al sol. Et por cada vna destas cosas que dicho auemos viene al falcon grand enfermedat, de que el falcon pereçe muy ayna si non es acorrido, et es muy malo de guaresçer, ca todo se rrcsfria et desordénasele todo el cuerpo, et deues conosçer esta dolençia por esta guisa: quando el falcon regita á menudo, et non logra cosa que toma, pero que ha fanbre, et tiene buen senblante fasta que falleçe de la carne, et entonçe entristece, et guárdate que antes que así entristezca, que le acorras, ca si le non acorres luego que comiença á regitar, quanda despues le quisieres acorrer non le prestará, et la razon por qué es esta : porque el buche está ya encogido et el papo, et non quiere rreçibir cosa en sí nin vianda alguna, por ende te digo que le acorras antes çedo que tarde, et deues le acorrer por esta guisa: toma los palominos nueuos et yeguados I, et si palominos non podieres auer, toma palomas, como quier que palominos auras de palomas, ó de las que crian en casas domesticadas, et afógalos de guisa que se les cuaje la sangre dentro en ellos, ó la destilla 2 de guisa que la sangre caya linpia en vna escudilla, et luego como aquella sangre se cuajare, dágela al falcon á comer, et si vieres que lo lograre, dágelo así tres vezes en el dia, así fresco cuajado, et non coma otra vianda. Et luego otro dia mata vn palomino, et dale la sangre por la guisa que dicha es cuajada, et dale vna tetilla de palomino, sin pluma et sin hueso, et dende adelante dale buenas viandas poco á poco, et á menudo gallina, ó palomino, ó tórtola, ó cerçeta, ó ne-

1 B. Igualados. D. Aquados. E. Iguales.

2 B. ó los destetilles. 


\section{23}

greta, lo mejor que podieres, et si vieres que las dichas cosas non quiere lograr et las rregita, faz estos poluos que aquí dize, que son muy buenos, et todo caçador los deue sienpre traer consigo. Toma la nuez de India, la nuez moscada, et la mirra, et los clauos de girofre, et canela, et flor de canela, et maçis, et almástica, et ençienso, et azúcar blanco, et pisa et muele cada cosa destas sobre sy, et desque fuer bien molida et mezclado todo en vno, el azúcar blanco sea lo postrimero, et sean de todas estas cosas tanto de lo vno como de lo otro por peso, et toma destos poluos, et dale de comer en vn coraçon de gallina, et sea dada tanta quantía al falcon como dos granos de garuanços, et cada dia rrocíale el rrostro et la cabeça con buen vino blanco, et fártale de sol, et en quanto así fuere doliente, non le prueues el agua, saluo desque vieres que es ya bien esforçado. Et guárdate que todo este tienpo non le fagas prueua ninguna que sea, saluo gouérnalo por la guisa suso dicha, et á cabo de diez y ocho dias dale vna alina I de cabra caliente, ó de carne de la pospierna de vna liebre que sea caliente, et esto será por rremondar las tripas et el buche de la orrura de la sangre de los palominos que comió, et así guaresçerá.

I B. Alma. D. Alyano. 


\section{CAPITULO XXXIII.}

DE los falcones QUe SON FERIDOs DE AVEs.

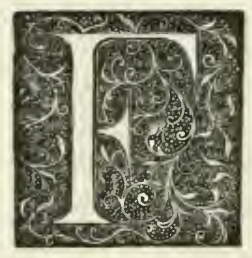

ERMOSA marauilla es, et otrosí grand bondat que vn aue tan pequeña como es vn falcon traue de vna crua, que es aue tan grande et tan braua, que quando vn ome la toma en vn lazo non osa llegar á ella, temiéndose del golpe que della reçela auer, et pues el falcon es loado por tomar vna tal aue, mucho mayor loor deue auer el caçador que por su sotil arte pone al falcon en se atreuer á ello, et auer tan esforçado el corazon. Ca el falcon desque nasció nunca tomó sí non pequeñas presiones, así como palomas et cornejas et ánades et çerçetas et otras tales aues semejantes, et el caçador fázele dexar aquellas presiones, ct cobdiçiar otras aues muy grandes, como gruas et garças et ansares brauas, çisnes, abutardas et otras que şon fucra de naturalẹza, ca nunca le vió ome á falcon 


\section{25}

brauo matar tales presiones. Et por matar tan grandes presiones acaesçénles grandes ocasiones de feridas que les dan aquellas presiones, así como la garça quando fiere con el pico, et la grua con la vña del pié lanzándole coz, et así de muchas maneras son feridos los falcones. Et quando tu falcon vieres ferido acorrerle as desta guisa: toma vnas tijeras muy agudas et trasquílale aquel lugar do tiene la ferida, et si la ferida es luenga, que puedan y ser dados puntos, toma vna aguja de pelligero muy sotil, et vn filo de sirgo retorçido, et cósegela, et sea cosida la carne et el cuero todo en vno, et los puntos que en la dicha ferida fueren dados, cada punto sea cosido sobre sí, et ligado sobre sí, et toma la suelda que dixe en el capítulo xxv, quando se le tira la vña al falcon, et lánçale della ençima de la ferida sobre los puntos, et otro dia toma el alosna, que es el ençienso amargo, et cuézelo en vna olla pequeña nueua con el vino blanco, et láuale aquesta ferida fasta que veas el cuero que es verde, que es tornado al color de quando estaua sano, et con vna péñola de gallina muy sotilmente le cata aquella ferida, et si la ferida entrare en fondo dentro al cuerpo, rrónpele el cuero á lo luengo, de guisa que le non rronpas la carrne, et esto le deues fazer, porque quando la ferida del falcon va fonda non se puede purgar del lixo I, otrosí, las peñolas métensele dentro, et el mal que ha de salir métesele, et tórnasele adentro, et esta rronpedura que se así ha de rronper non sea cosida, mas sea lauada con el vino et con el alosna, por la guisa que dicho hé, et si non fuere fonda non cures della, saluo que le lançes la suelda que está ordenada en el capítulo xxv, et láuala

I B. Limpio. D. Laxo. 


\section{6}

con el vino et con el alosna fasta que sea sana la ferida. Et si la ferida es pequeña, que non ha menester de ser cosida, láuagela con vino, et con el alosna cozido, et échale de la suelda, et luego será sano. Et cátalo vna vez en dos dias, et cada vez que lo lauares con aquel lauatorio dende adelante non le pongas de los dichos poluos de la suelda, saluo lauárgelo con aquel vino fasta que traga buena color la llaga. 


\section{CAPITULO XXXIV.}

DE LA FERIDI INEL FALCON.

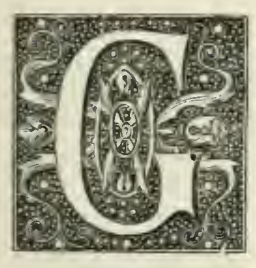

RAND bien es et grand bondat al caçador fazer al su falcon buena alcándara, et bien fuerte et bien liada, et gruesa et linpia, que gallinas non ayan estado en ella nin otras aues, ca enxenplo et cartigo es dado de luengo tienpo á los caçadores que tan firme et tan bien fecha et tan buena deue fazer alcándara para su falcon por vna noche como para in año, et esto es por muchas ocasiones que pueden contesçer á los falcones en las alcándaras que firmes non son, et esto que sea verdad ya contesçió á muchos falconeros curar desto poco; et por ende contesçe á sus falcones que se les mueren et se les quebrantan piernas, ó alas, et fueron lijados por caer el alcándara con ellos. Otrosí, se lijan algunos falcones por topadura, encontrando en la rribera in falcon con otro, lo que acaesçió 
muchas vezes, et venir el falcon en pos alguna rralea, et vençiendo la topa el falcon en tierra ó en áruol; et recibe et falcon grand ocasion bolando en la rribera en lugar do ay árboles. Et quando el falcon sentieres que está ocasionado de tales feridas como estas, farás así : toma la suelda que dixe en el capítulo xxviı, de la pierna quebrada, que se faze con la mumia, et dale della de comer nueue dias, segund ay está ordenado de tres en tres dias fasta que sea sano, et sean nueue dias dándole aquellos poluos con la pierna de vna gallina tierna, cada vez la quantía de dos garuanços en vn coraçon de gallina. Et sy vieres que aquella cayda ó topadura faze finchazon en algund logar, et touiere así sangre ayuntada, rónpele aquel cuero et auentarse á aquella sangre, et á esta ron-pedura fecha non le eches ninguna suelda, ca non se faze sinon porque aquella sangre quebrantada salga de ally, saluo láuale con el vino blanco, et el alosna, que es ençienso amargo, et si de la dicha cayda non se ayuntare sangre nin de la dicha topadura, saluo para aquel lugar negro, láuagelo con vino et con alosna, como dicho es, et déueslo poner en uara en quanto estouiere mal trecho, et non le traigas en la mano. 


\section{CAPITULO XXXV.}

DE LA ABATIDURA DEL FALCONI.

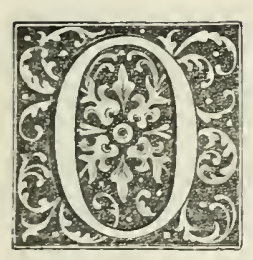

TROSÍ, te digo que de tales caydas, et de las abatiduras del alcándara, et de la mano del mal caçador resçibe el falcon grand quebranto, et desto el caçador deue ser testimonio el que lo trae en la mano, et lo puede veer et entender, et quando así gelo entendiere, luego le dé de comer de la suelda que está ordenada para el cuerpo del falcon en el capítulo xxvi1, de la pierna quebrada, et avn te digo que

I Casi todos los MS. excepto el del señor conde de Altamira, que nos sirve de base para nuestra publicacion, por ser el más antiguo, hacen uno solo de este y el anterior capítulo, de suerte que de aquí en adelante hay un número de diferencia en los capítulos del MS. A., que es el indicado, y los restantes, hasta el capítulo xlrı, en que vuelvená concordar. 


\section{0}

la abatidura ó derramadura de la alcándara es mucho peor que la de la mano, porque el falcon non es tan ligero en su debatir como el açor, et quando se debate non se puede tornar á la vara, et siéntese muy mal de las piernas, et guaresçe muy tarde dello, et otrosí en las batiduras quel falcon faze en el alcándara párale sienpre mientes en la espuela del pecho del falcon, et cata si faze ally alguna postilla ó llaga, et si vieres que faze postilla, ponle el inguento çetrino, et búscalo en los çerujanos, otros le llaman vnguento amarillo, et luego será sano. Para todas las otras batiduras dale sienpre de la suelda cada vez que entendieres que tu falcon es sentido ó quebrantado, ca es muy preçiosa melezina, ordenada en el capítulo xxvir, et guárdate sienpre de poner tu falcon en logar do estas ocasiones resçiba. 


\section{CAPITULO XXXVI.}

DEL FALCON QUE TIENE I.AS TRIPAS FUERA.

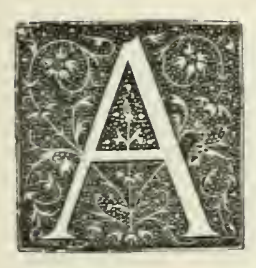

LGUNAS vezes salen las tripas al falcon de golpes de garças, ó por otras ocasiones, et quando vieres á tu falcon las tripas así fuera, derriba el falcon sobre la parte sana en manera que la llaga esté por ençima, et tórnale las tripas en su logar, et cose aquel logar por do salieron las tripas, et lança en aquel logar de la suelda que está ordenada en el capítulo xxv, de la vña del falcon, et si vieres quel cuero está junto con la carne, cóselo todo en vno, et lánçale la dicha suelda, et si el cuero está sobre sí, et la carne sobre sí, cósele cada vno sobre sí; et si lo fezieres delante de çerujano será mejor, porque avrá buen tiento en el coser, et desque fuere cosido, lánçale de aquella suelda sobredicha. Otrosí, te digo que acaesçe algunas vezes traer el falcon las tripas fuera entre el cuero et la carne, 
así como verás algunos buyes á que otro buey da con el cuerno, et le forada la yjada, et non le forada el cuero, et trae las tripas entre el cuero et la carne, et quando tal dolençia vieres al falcon, acorrerle as desta guisa : derríbalo et tórnale las tripas dentro al cuerpo por aquel forado onde salieron, et verás entonçes fincar el cuero en que andan las tripas flojo, et apáñalo todo, et átalo con vn filo torçido bien á rrayz de la carne desque fuere bien apañado con la mano por ençima, et el cuerpo que sobrase ençima córtalo por ençima del atadura con vna navaja, et toma los fierros fechos por esta guisa,

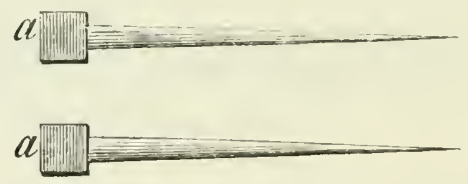

et sean tan luengos como vn xeme, porque avnque los escalientes los pueda ome bien tener, et caliéntalos del lugar do son quadrados, et han de ser estos fierros bien limados et quadrados ençima de los dados, et bien llanos de toda quadra, et en las astas bien limados, et bien rredondos, et caliéntalos bien del lugar en que es quadrado, et pónlos dos ó tres vezes ençima de aquel lugar do tajares así el cuero, et sea tan grande la vna quadra como la otra, et despues de lo que está de yuso do están las letras $(a, a)$ por señal, le pon ençima del cuero cortado, en manera que aquel cuero cortado se vaya encogiendo con aquel fuego que le darás; et dale de la suelda que está ordenada en el capítulo xxvir á comer, por la guisa que está en el dicho capítulo ordenada, et guárdalo que non se debata fasta que sea sano. 


\section{CAPITULO XXXVII.}

DEL FALCON QUE TIENE LAS QUIJADAS TORCIDAS.

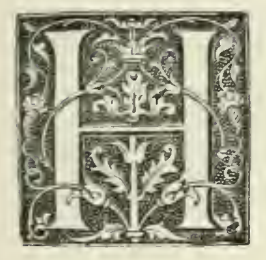

AY algunos caçadores que quando quieren yr á algunos lugares á librar sus negoçios an por enbargo de leuar sus aues en sus manos, et por yr más desenbargados déxanlas en sus alcándaras, et ay falcones que son quexosos, et porque non quieren asosegar en el alcándara, pónenle el capirote, et porque se le non caya, pónenle vna contrapesa á la correa del capirote, et quando el falcon se rrasca por derribar el capirote et non puede, va con el pico á los costados do siente que anda la correa del capirote, et quiere tirar della con el pico. Et quando así traua el falcon con el pico en la correa, el contrapeso non le deja salir fucra, et métesele la correa por la boca al traués de las quixadas del falcon, et quando el falcon quiere tirar el pico afuera, non puede, ca nọ lẹ dexa la correa, et con la fuerça del tirar que 


\section{34}

así tira, tuérçensele las quixadas et sálenle de su lugar, de guisa quel falcon non puede cerrar la boca, et tiénela desuariada et desuiada. Et quando tal ocasion como esta vieres á tu falcon, derríbalo, et métele los dos dedos en la boca, aquellos que vieres que mejor le caben ó pueden caber, et vn dedo sea de la rna mano, et el otro de la otra, et entonçe arriedra con el vn dedo por el cabo del vn carrillar de la boca, et con el otro dedo por el otro carrillar, et despues tírale los dedos, et cierra la boca, et despues déxagela abrir, et si vieres que abre la boca desvariada, entiende que las quixadas non son en su lugar, et de aquel cabo que vieres que la boca tiene tuerta, métele vno de los dedos que vieres que mejor se puede poner de sí, tírale la quixada contra el cornejal de la boca donde la quixada está fuera, et así fasta que veas que las palas de yuso están ygualadas con el pico, et non le des de comer, saluo picada la vianda, et dale á comer de la suelda que está ordenada en el capítulo xxviı, de la pierna quebrada, et dágela en vn coraçon de gallina de tres en tres dias por nueue dias; et así lo gouierna fasta que lo veas bien esforçado, et que comiença á poner el pico por sí, et entonçe dale á comer su vianda como ante solia. 


\section{CAPITULO XXXVIII.}

CÓMO DEUES FAZER LA MUDA Á TU FALCON.

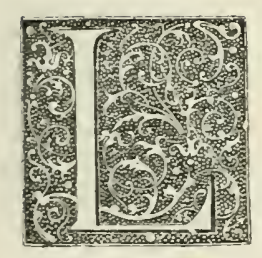

OS falcones baharís sardos et mallorquinos et de rromanía et tagarotes son los falcones de todos los plumajes que más ayna comiençan á mudar, et así salen más tenpranos; et yo ví vn falcon del rey don pedro, que dizian doncella, et era bahary de rromanía, et era garçero et altanero, et vilo la primera semana del mes de agosto ser ya fuera de la muda et desaynado, et aquella semana matar vna garça; pero comunalmente los otros plumajes todos comiençan á mudar la primera semana del mes de junio, et vnos más tenprano et vnos más tarde, segund acaesçe. Et por tanto es bien que le fagas su muda en casa buena do non llegue fumo nin mucho roydo, et esto digo por el falcon nebly, ó girifalte, ó baharí, ó sacre, quel borny et el alfaneque mejor mudan do veen los omes, et faz á la 
casa do la muda fezieres que non entre fumo, nin la lunbre, si non vna ventana que le abras quando quisieres, porque el falcon asosiegue, et fazle la muda alta de tierra por la humidat, sobre maderos rrezios et tablas et enbarrada, et ponle ally vna piedra, et sienpre le ten linpia la muda, et tenga su arena, et de noche tenga vn candil de azeyte que arda toda la noche, et algunas vezes ponle algunos çéspedes uerdes como en manera de prado, que tome plazer con la verdura, et dale de comer en la mano en cuanto él quisiere, señaladamente en las tardes con la fria, tómalo en la mano et dale ally de comer, et todavía le cata si está alegre, ó qué senblante tiene, porque si menester ouiere de lo curar, que lo acorras. 


\section{CAPITULO XXXIX.}

DE Algunos FAlcoNes QUE NO QUIEREN MUdir, ET CóNo FARÁS PARA QUE TU FALCON MUDE MUY AYNA.

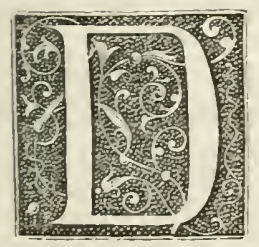

ESPUES que vieres que tu falcon comiença á derribar las péñolas, como coruas et cabo cuchillos, tráelo en la mano et non lo pongas en la muda fasta que derribe péñolas de la cola, et ponle carne, et coma quanto quisiere, et dale buenas viandas, et desque vieres que derriba de la cola, porque seria peligro si se debatiese et quebrase alguna péñola en sangre, ponlo en su muda, et dale tórtolas bien çeuadas et bien gordas, et palominos enxutos, señaladamente quando ha de gouernar las péñolas mayores, et quando le dieres estas aues, pélalas biuas, et alínpialas con vn trapo áspero, por el piojo, que non les finque. Pero ay algunas rrazones por qué los falcones han enbargo en la muda, et non quieren mudar: la primera razon es por auer en sí alguna enfermedat; la otra, por non en- 


\section{8}

trar bien purgado en la muda, et la otra, por saña que el falcon toma en la muda, et non quiere asosegar. Et quando es el enbargo primero, que dixe de non mudar por alguna enfermedat quel falcon há, á esta rrazon digo que lo saques de la muda, et pára mientes en él, et guarda bi nn su senblante, et segund las señales de la dolençia que en él vieres, cura dél segund está ordenado en cada capítulo deste libro que fabla de su dolençia, segund la dolençia manda. Otrosí, si el falcon dexa de mudar por la segunda rrazon que diximos, que non entre el falcon bien purgado en la muda, et deste enbargo el caçador es en grand culpa, ca esto es vna cosa quel caçador deue tener en cuydado de purgar su falcon á la entrada de la muda, et á la salida, á esto digo que lo saques et lo fagas por la guisa que dicha hé, et púrgalo. Otrosí, si el falcon dexa de mudar por la tercera razon que diximos quel falcon dexa de mudar por saña et orgullo que toma, et non quiere asosegar, et á esto puedes acorrer ligeramente: saca el falcon de la muda tres ó quatro dias, et dale poco de comer en estos dias, de guisa que aya buena fanbre, et desque vieres que así há buena fanbre, tórnalo á la muda, et atápale bien la muda que sea bien escura, et dale poca vianda fasta que veas que es así asosegado, et desto se entienda que non coma sobejo, mas coma tenpradamente et con fanbre, et lo que deuen fazer despues es darle sus buenas viandas, et algunas vezes darle en ocho dias vna vez ansaron, ó carnero bien caliente de la pierna, por tirar el enfastío de las otras viandas que come de cada dia, et luego al comienço darle las tórtolas, que son muy buenas para poner el falcon en carne. Pero despues quel falcon comiença á derribar las péñolas mayores, son buenos los palominos, que son calientes, et ayúdanle á vẹnir las péñolas grandes, señaladamente los cuchillos 
mayores que están en logar de pequeño gouierno, que son las alas, et han menester ayuda, et los palominos enxutos et yguados I es la mejor vianda que estonçe le puedes dar, et es bueno mudarle las viandas, porque non se enfastien. Otrosí, es bueno darle las landres de los cabrones et cabras que les fallares en el pescueço; et en la garganta, et tras las orejas, et dágelas tres vezes en la semana, et fazle dellas papo comunalmente, et si el falcon se enoja dellas, dale otra vianda, et desque en aquella començare á comer, tórnale á dar las landres, et esto le faz fasta que veas que derriba las péñolas comunalmente. Otrosí, toma la nuez del garguero de la cabra ó del cabron, et pícala bien menuda, et dale della con las dichas landres. Esto faz á vnos falcones que derriban á pereza sus péñolas, et todavía le da de los palominos enxutos, et aquellos les fazen vestir bien et de fermosas plumas et sean yguados 2 .

I B. Igualados.

2 B. Igualados. D. Gordos. 


\section{CAPITULO XL.}

CóMO FARÁS DESPUES QUE TU FALCON FUERE MUDADO.

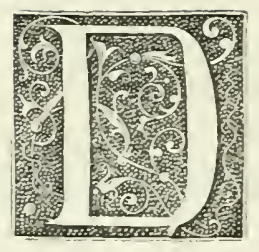

ESPUES que vieres que tu falcon ha derribado todo lo grande, et están ya en el cuchillo postrimero et tijera, vele tirando carne et dale la ménos vianda, en guisa que la coma con fanbre, et raya gastando de su vagar del sayn que tiene, et esto aprouecha á que saldrá de la muda más seguro et ternás ménos de trabajar en él, á ménos peligro del falcon, ca quando salen muy çerrados de carne es grand peligro si se debate et le quebrase sayn, ca nunca en aquel año andaria como deuia nin lo podrias ordenar bien. Et desque los cuchillos et tijeras ouieren derribado, et apuntan las tijeras quanto dos dedos, sácalo de la muda en la noche et ande en la mano, et madruga bien con él dándole sus pollos pequeños afogados en agua fria, por rrefrescar el falcon, et destas viandas delgadas et frias 


\section{I}

fazle buen papo, et si feziere fiesta, ponlo en rna alcándara en casa fria et escura, que non entre ay quien lo espante, et desque fuere tarde tómalo en la mano, et así le faz de manera que vaya gastando el sayn, et le finque buena carne, et desque fuer desaynado, fazlo bolar al senuelo á la tira, et algund poco el rrecuesto arriba, ca non ha cosa en el mundo que más desayne al falcon quel bolar á la tira, et todavía non se te olvide de las plumas juntas cada tarde mojadas en el agua tibia desque començare á auer fanbre, ca en quanto estouiere çerrado non las querrá tomar. 


\section{CAPITULO XLI.}

DE LOS AÇORES.

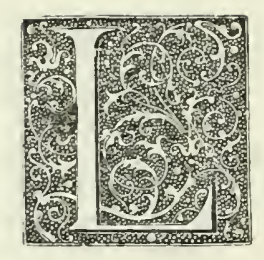

OS açores crian en muchas partidas por todo el mundo, pero de los que nos sabemos son los mejores açores de noruega, et en Asuega, et en aquellas comarcas do deximos que crian los neblís et girifaltes et otros falcones. Et los açores que ally crian son muy grandes et fermosos et de grande esfuerço, et avn ally ay vnos mucho mayores et mejores que otros, et porque luego to digamos, las sus façiones de los açores deuen ser tales como aquí dirémos: deue auer grand pinta granada, et la tetilla et el pecho grande, et buena cuxa, et buen çanco, et los dedos gruesos, et el cuello delgado, et la cabeça pequeña, et el rostro muy grand et luengo, et la ventana buena; et comunalmente los açores de noruega han estas figuras, ó los más dellos, et estos açores de noruega tráenlos á flandes 
en las concas de alemaña, et estonçe traen los girifaltes, et neblís, et otras aues, et de ally de frandes liéuanlos por todas las tierras, así como en francia, ytalia, españa, et otras comarcas. Et en todas aquellas tierras saluo en españa non curan de tomar perdizes con el açor, saluo todas presiones gruesas, así como grua, garça, abutarda, et toman con ellos faysanes, que buelan como perdiz, et quando toman las presiones gruesas, todavía toman galgo et lo lieuan para que acorra, porque el açor non trabaje mucho, et traen los açores capirotes, et en verdat non los tienen tan guardados como en españa fazen, ca toman algunas vezes con ellos la liebre et conejo, et rónpense en ello, et creo que los auenturan así porque hay muchos dellos, et en españa, como los han pocas vezes así açores escogidos, préçianlos mucho, et guárdanlos, et non toman con ellos saluo perdizes et garça comunalmente, et tienen que es bueno tomar el açor perdiz, que es muy bien, ca le saca el buelo, como la perdiz buela luengo trecho, et desque el açor vna vez buela á lo luengo, tienen que todas las otras presiones toma más ligeramente, ca el açor et qualquier aue de caça por mayor trabajo há el bolar que el trauar. Otrosí, los açores de noruega torçuelos salen muy buenos perdigueros, et son más ligeros que las primas, pero los torçuelos son más malencónicos, et las primas et torçuelos de noruega de su naturaleza son muy espantadizos. Et otros açores crian en yrlanda, que es en la ysla de inglaterra, et son más pequeños, et son muy blancos, et salen muy buenos. Et otros açores crian en esclauonia, que es en grecia, et son llamados esclauos, et son buenos, pero non como los de noruega. Otros açores crian en çerdeña, que es ysla, et son llamados sardos, et son pescoçudos et cabeçudos, et toman bien ánade, et cuerua, et algunas perdizes, pero 
non muy bien, ca luego se fazen rregateros. Otrosí, açores crian en el ducado de borgoña, et son pequeños, pero salen buenos. Otrosí, en castilla crian açores en muchas comarcas, así como en lipúzcua, et en álaua, et en vizcaya, et en segura, que es de la órden de santiago, et en algezira, et destos los mejores que yo ví son los de algezira, et son açores pequeños, et roquezes ; los otros, comunalmente los torçuelos, son muy buenos perdigueros, et de las primas son comunales, et quando son pollos han rn plumaje bermejo, et la punta preta; non son bien enplumados, et son estrechos, pero algunos dellos salen buenos, pero son de malas costumbres. Otrosí, açores toman brauos en el tienpo que se toman las torcazas et vienen con aquel paso, et destos los más et los mejores se toman en castilla en vna villa frontera de nauarra que llaman santa cruz de canpeço, et son de otra pinta que los que agora deximos, et son grandes asaz, et paresçen en el plumaje á los açores de noruega, ca el plumaje han entre blanco et amarillo, et la pinta gruesa, et salen muy buenos, et si son mudados de vna muda en el ayre valen más si han caçador sofrido que los faga de su vagar et sin malenconia, et los señores preçian mucho los açores buenos, ca son muy fermosos et de buen donayre, et toman delante dellos las presiones; otrosí, son buenos para tomar raleas traynas para fazer á los falcones, así como garças, gruas, et otras, et los açores quieren ser muy bien traydos en la mano, et pensados de buenas viandas et buena alcándara, et fártalo de sol et de agua, et non quieren estar en el alcándara entre mucha gente, saluo en lugar apartado, et piensa mejor de sí. Otrosí, en quanto podieres escusa de tomar con tu açor cueruo carniçero, ca et mala presion, nin budalon, ca ensañan mucho et escarmiéntanlos. Otrosí, non tomes con él milano 


\section{5}

despues de mediodia adelante, ca están ya los milanos çeuados, et quando los toma el açor regitan lo que han comido, et enojan el açor, et aborresçen por ende de tomar otras presiones. Otrosí, escusa de tomar con él abutarda et ansar braua, ca los ronpen mucho et se buelan con ellos. Otrosí, quando ouieres de lançar tu açor á garça, guisa que falle la garça leuantada, ca si está posada et llega á ella fiérele mal; otrosí, nunca lo lançes á liebre nin á conejo, et dale así sienpre á tirar et á pelar, et en la muda esté en buena casa de grand espaçio, et suelto, et tenga dos alcándaras et vn baçin de agua, et coma en la mano. 


\section{CAPITULO XLII.}

I) LOS GAUIT,ANES

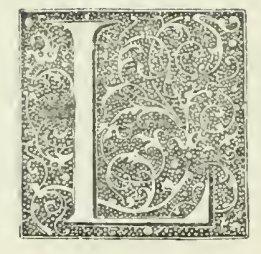

OS gauilanes son aues de caça muy lindas et gentiles et de grand esfuerço, et en todas sus costunbres et façiones paresçen ser açores pequeños et açores de noruega, ca así há el plumaje et la pinta, et los gauilanes crian en muchas partidas, et crian en árboles, et dizen que los que crian en el espino son más ruuios que otros, et esto non les viene por el espino; mas todos los gauilanes ruuios son de grandes presiones, et por tanto crian en árboles baxos, por leuar más ligeramente la presion que toman á los fiios, et el espino es baxo et árbol espeso, et por tanto crian ally. Et los gauilanes que crian en los valles de las montañas son mejores que los que crian en lo alto, et todo esto es por esta razon sobredicha que agora deximos. Et de los gauilanes en españa los mejores que yo 


\section{7}

sepa et mayores et de mejor esfuerço, son los que crian en el pedroche, que es en término de córdoua. Otrosí, son buenos los gauilanes que crian en aybor, que es en término de guadalupe et de trugillo, et destos gauilanes et de todos los otros son los mejores los que toman rameros, que son criados más á su voluntad por el padre et la madre, et oy dezir que ruy paez de biezma, vn caballero muy grande de galizia, viniendo de la guerra de los moros, et yendo para su tierra, pasó en el tienpo de los gauilanes nueuos por el pedroche, et fizo leuar ally veynte gauilanes nueuos, primas et torçuelos, en sus alcahazes I, et desque los touo en su tierra fízolos echar en vn monte suyo, et dizen que despues acá ay ally en aquella tierra et comarca muy buenos gauilanes, mejores que primero auia. Et los gauilanes quieren ser bien traydos et bien gouernados de buenas viandas, et requeridos de sola agua, et que desplume á menudo, et buena alcándara, et buena casa sin fumo, ca si fumo les da ó sereno, luego son perdidos. Et toman presiones muy buenas con que toma ome plazer, así como en el verano los perdigones, et despues en el mes de agosto et setienbre las codornices, et en el ynuierno las çerçetas con el atanbor 2, et la picaça et la ciguñela, et otras presiones por todo el año, et son aues que non pueden sofrir purgas, porque son muy delicadas, et por tanto el su gouernamiento para los traer sanos es buena vianda, et non les dar grandes papos, mas poco et á menudo, et son aues que toman con el grand esfuerço que hán algunas vegadas grandes presiones, así como tomar el ánade et la cuerua, et trauar

1 D. Alcándaras.

2 B. Alcambor. D. Latambor. 
del milano, et tomar el alcarauan, et por tanto los llaman por su nonbre en latin nisus, que quiere dezir esforçado, et en francia et en otras partes lo llaman esparuel, et son los gauilanes más priuillejados que ninguna otra aue de caça, que qualquier mercador que lieue falcones á vender pagará portadgo, et si leuare vn gauilan con ellos es franco, et yo vilo en cañete, vn lugar rribera del mar, que es del visconde dilla en el regno de aragon; ví llegar vna barca que vinia de prouençia, et vinian diez et siete mercadores que trayan sacres de rromanía et de alemania, falcones bornis prouinçiales ochenta pieças, et trayan vn gauilian con ellos, et desque llegó ally en el puerto murióseles el gauilan, et non leuó dende los falcones fasta que fué á perpiñan, et dió vn falcon prouinçial á vn cavallero dende, et tomó del vn gauilan, et tornó para ally, et leuó sus falcones porque yua ya seguro de non pagar portadas, et si en ynuierno lo quisieres pasar, dale buena casa caliente, et piernas de gallinas, et paxarillos, et fártalo de sol, et guárdalo de viento et de sereno et de fumo, et dale buena alcándara, et pónle vn paño de color so los piés ó vn pellejo de liebre, ct non le des víanda, sinon que tenga pluma, et en sus façiones todas cata que sea el gauilan enano et de buena carne, et buen rrostro, et buena ventana, et grand mano, et los dedos luengos, et los gauilanes ruuios son más ardidos, et non te pagues de gauilan que sea estrecho de onbros, nin çancudo de luengas piernas, et dale buena piuela blanca et delicada, et cascaucles pequeños, et de buen sonar, et si çahareño fuere, ay algunos que los vsan el capirote, et andan más guardados, por ende traen más rezio el cuerpo et las piernas, ca lo escusa de se abatir. 


\section{CAPITULO XLII.}

DE LOS ESMEREJONES.

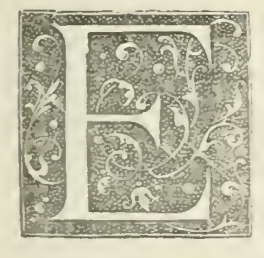

SMEREJONES son aues que parescen á los falcones en todas sus façiones, así como paresçen los gauilanes açores, et ay en los esmerejones plumajes, así como hay en los falcones, ca ay dellos girifaltes, et neblís, et baharís, et sacres, et bornis, et estos crian segund dizen en noruega, et en aquellas partidas do crian los neblís et las otras aues, et vienen con el paso de las aues, así como vienen los neblís, et son aues muy ligeras et plazenteras, et buelan et toman bien la cogujada I, et el aloya, et avn toman perdiz, et yo ví vn esmerejon á don felipe, fiio del rrey de francia, duque de bregona, et conde de frandes, que le confiara la $\mathrm{d}_{\text {uquesa de bretaña, dizíame que en aquel ynuierno quel }}$

B. Copada. D. Congujada. 


$$
150
$$

lo ouiera que auia tomado dozientas perdizes, ó más, et era sacre de su plumaje, et quieren los esmerejones traerse en la mano como neblí, et non los oluidar en el alcándara, et quieren ser gouernados de buenas viandas et pequeños papos, pero son aues que ayna se pierden, ca son muy bulliçiosos et de poco sosiego. 


\section{CAPITULO XLIV.}

DE LOS ALCOTANES 1 .

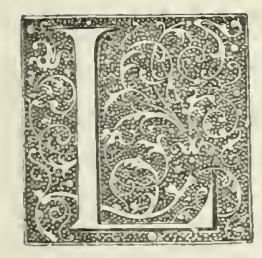

OS alcotanes son mayores que los esmerejones; parescen algo falcones; crian en aragon y creo que en todas partes. Los pollos sacados del nido no valen nada; tomados del ayre es un muy hermoso buelo, y quanto ménos mudas ticne es mejor. Son mal acondicionados algunos dellos, et es menester tener mucho sufrimiento. Lo que vuelan es el çaboque puesto en el ciclo : uerdad es que no se aciertan todas vezes. Tanbien vuclan la bubilla, y hanla de volar con la lonja, porque como tiene malas vueltas encuéntranse con ella y enbaráçanla: muy pocas veces la matan. Suelen ser perdigueros, tienen poco sosiego, como los esmerejones.

I Falta este capítulo en los MS. A. D. 


\section{CAPITULO XLV.}

DEL PASO DE LAS AUES.

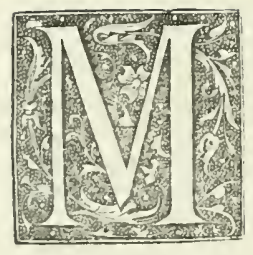

UCHAS vezes auemos dicho en este libro cómo los falcones neblís et otros vienen con el paso de las aues en esta tierra, et agora queremos aquí dezir qué paso es este de las aues, de que fezimos mençion. Et deuedes saber que á todas las cosas que Nuestro Señor Dios crió dió su gouerna. miento, et por ordenamiento de la natura han su industria para viuir. Et por ende dize el profeta david en el salmo alabando á Dios et á las sus obras, et dize así: el señor que da así á las bestias su mantenimiento á ellas perteneciente, et eso mismo á los pollos fiios de los cueruos llamantes á él. Et dizen los filósofos naturales que el cueruo quando vee los fiios salidos de sus hueuos cubiertos de pelo blanco, que los non conosçe por sus fiios, porque los vee blancos et non son de su color, et abor- 


\section{53}

réçelos, et non los quiere çeuar nin dar de comer, et en aquel tienpo que ellos así están desanparados de los padres, abren las bocas con la fanbre dando bozes; et ally péganseles mosquitos et formigas, de que se mantienen; otrosí se mantienen del roçío del çielo, abriendo las bocas fasta que van cobrando el su pelo preto que han de naturaleza, et los van conoçiendo el padre et la madre por sus fiios, et los tornan á gouernar, et así prouec Dios á ome et á animalías et á aues et á todas las otras cosas, segund que en muchos lugares se podria poner en exenplo, et así las aues por el industria de la natura buscan su vida et su mantenimiento, et señaladamente las aues buscan su vida en la morada del ynuierno et del verano, ca las aues que crian en noruega, así como neblís et sacres et bornis et otras aues, con el ynuierno, porque es muy frio, salen de ally de noruega et de aquella tierra muy fria, et vienen con otras aues á buscar tierra caliente, et vienen caçando en aquellas aues que vienen en su conpañia, et así derraman por muchas ticrras donde los toman. Et otras aues ay que magüer son en tierra caliente, buscan avn muchas más, así como las çigüeñas et sisones, et otras muchas aues que crian en esta tierra de europa, que contiene españa et francia et otras ticrras. Viene el ynuierno, pasan alen la mar en áfrica, porque es más caliente, et tórnanse, et yo ví por el estrecho de marruecos, que es entre tarifa et çebta, pasar las çigüeñas al cabo del verano, et se tornauan para áfrica, que tantas eran que non podia ome contarlas, que durauan grand trecho por el çielo, que yua la manada dellas, et eso mismo las garças, et otras aues. Et así dizen que lo fazen las codornizes, ca muchas vezes falla ome con vn viento muchas dellas, et luego que otro viento viene parten de ally et vánse, et esto vieron muchos. Otrosí, yen- 
do el rey don pedro por la mar, auiendo guerra con el rey de aragon, trauesando del cabo de martin á iuiça, que es trauiesa de doze leguas, ví que en la galea de vn cauallero que llamauan orejon, bien á seys leguas de tierra, cayó vna codorniz, non sé si yvan otras, pero dizen que pasan la mar. Otrosí, ví en el camino de la trauiesa de mar que se faze entre bermeo, villa de vizcaya, et la rrochela, que pueden ser ochenta leguas poco más, yeñdo yo en vna galea á media vía de mar, que podia ser á quarenta leguas de tierra de cada parte, fallé garças que lleuauan aquella vía mesma, et así andan buscando su vía et su paso las aues por su naturaleza; et así los neblís siguen estas aues, et atrauiesan todo el mundo. Et yo oue vn falcon nebly, que era muy buen altanero, et llamábanlo poca ropa, et fué tomado en plazençia, et díxome el rredero que lo tomara, que le cayera en la rred con vnas palomas torcazas en pos que él venia, et dizia que las palomas trayan el papo lleno de fruta de la faya que llaman ho 1 , et aquella mañana la auian comido, et non fallamos que ouiere faya fasta villafranca de montes doca, que habia bien setenta leguas de ally, et por tanto podedes entender la trauiesa que las aues fazen. Et non ay dubda que muchos falcones neblís son tomados en las rroçinas, et en el canpo de santaren con el pelo blanco con que nasçieron en la cabeça, et verás si han bolado et trauesado de tierra de noruega aquí. Otrosí; ví en tierra de toledo, vn año que fuéron tomadas muchas tórtolas en el mes de setienbre, que vinian posar en las oliuas, et matáuanlas los vallesteros, et muchas dellas trayan ençienso en los papos pegado, et dizian que podia ser que vinian de la tierra onde naçe el ençienso,

1 B. Hoc. D. Lio. 


\section{55}

et que posauan en los árboles do ello era. Otrosí, en tierra de soldan de babilonia ay comarca que suelen venir en tienpo cierto de paso, et dizen que pasan la mar, et quando ally llegan que vienen muy cansadas, en manera que non pueden bolar si non muy flojo et baxo, et el soldan tiene sus atalayas en aquel tienpo por todas aquellas comarcas do ellas suelen venir, et va allá, et lieua muchos girifaltes, et dizen que dura aquel paso quinçe dias, fasta que las gruas son descansadas para partir dende que van para otra tierra; et con aquellos girifaltes toman muchas dellas, et yo ví en paris vn mercadero genoués que dizia que moraua et tenia su casa et mercaderías suyas en damasco, que es del dicho soldan de babilonia, et tenia en paris entonçe omes de alimania que leuauan girifaltes para el soldan, et eran los que yo ví en quatro caxas, que ellos llaman, que nos dezimos acá varas I, ochenta girifaltes, que eran todos roquezes, et dizíame que le auia enbiado bien otros tantos, et que quando allá llegauan que tanto le dauan et pagauan por el que muria en camino como por el que llegaua biuo, et esto faria porque los mercadores non dexasen de lleuarle falcones, por quanto de noruega et la alta alemania, donde los trayan, á damasco es muy luengo camino por tierra et por mar. Otrosí, ví veniendo de la rochela en españa, bien á veynte leguas de tierra, venir á mi galea vn çerrenícalo, et muy muchos paxarillos pequeños, et posauan en el árbol de la vela, et luego que alçauan ó abaxauan el mastel, bolauan vn poco fuera de la galea por sobre mar, et de sí tornáuanse á la galea, et tomáuanlos á manos, et estos non sé si pasauan en otra tierra, et dizian algunos que

D. Barcas. 
muchas aues bolauan por la mar cuydando que es más estrecha, et desque cansan caen, et piérdense en la mar, et si fallan algund navio, vánse para él, et posan ally, et paresçe por el cueruo que noé enbió, que por quanto falló la tierra cubierta de las aguas, ct non falló do posar, tornóse á posar en el arca ; et así como auemos dicho, de muchas maneras pasan las aues et atrauiesan el mundo, et con aquellas vienen los falcones çeuándose en cllas, et los más dellos pollos. 


\section{CAPITULO XLVI.}

DE Cómo SE DEUen ENXERir las péÑolas QUebradas.

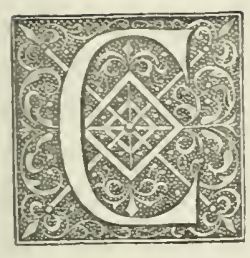

OMO quier quel enxerir de las péñolas del falcon et del açor todos los falconeros et caçadores comunalmente lo sepan fazer, enpero pues que en este libro auemos fablado de todas las cosas et curas que pertenescen á las aues de caça, pornemos aquí la manera et plática cómo las péñolas quebradas de las aues se deuen enxerir, porque las aues cobren todos sus buelos enteros. Ca paresçe muy feo quando el aue trae el ala mellada et menguada de sus plumas, et es grand dapno al aue, lo vno non buela tan bien, ca non resçibe tan bien el viento en el ala aportellada como quando la tiene çerrada et guarnida de sus péñolas. Otrosí, desque vna péñola se quiebra, las otras péñolas que están á par della peresçen et van á mal, ca vnas á otras se ayudan et se sostienen. Otrosí, non es 
onrra del falconero et del caçador en que su aue ande así, et pareçe en ello mucho la su negligençia, ó que la guardó mal, ó que se maltrató por su culpa, ó que non pone en ello remedio qual cunple. Et por ende deuedes saber que por muchas guisas se quiebran las péñolas á las aues; lo vno por el traer, quando los mercadores traen muchas aues en varas en vno et luengo camino, et non pueden así curar de tantas aues ayuntadas, demás que non vienen en la mano, saluo en aquellas gauias que les fazen; et por ende las aues como vienen çiegas con los capirotes et así allegadas marrótanse mucho. Otrosí, se marrotan las aues et quiébranseles muchas vezes las péñolas por tomar grand presion, et volarse con ella por la non poder tener á su voluntad, así como quando toma el açor abutarda, ó ansar braua, ó el falcon nebly quando toma por rralea, ó alguna tal presion. Otrosí, pierde et quiébranseles algunas vezes las péñolas al aue por mengua et negligencia et poco saber del caçador, dexándolo en el alcándara oluidado, et debátese, et non le toman nin curan dello, et tuérçensele las péñolas, et non curan de le acorrer et de gelas endreçar, et dende vienen á quebrar, et dende adelante vienen aquellas péñolas quebradas todavía á marrotar más, fasta que fienden et vienen á ser corronpidas et cortadas fasta lo biuo; et si acaesçiere que la péñola sea así quebrada et rronpida fasta lo biuo, entonçe non ay rremedio para se poder enxerir, et finca"la tal péñola en aventura de la mudar el aue, ca quando viene á la muda non se puede ayudar del pico á trauar della para la mouer, como faze á las otras péñolas, et si es al comienço de caçar non buela el aue tanto como deue, et las otras péñolas andan en ocasion por ella, et el remedio que aquí se puede poner es este : toma vnas turquesas pequeñas que llaman tena- 
zas, como aquellas del menester de los falcones con que les cortan las vñas et el pico, mas cátalas que non sean agudas nin corten, et derriba tu falcon, et cógelo, et tráuale de aquella péñola con aquellas torquesas, et sácagela, et de sí ponle en aquel forado por do salió vn grano de çeuada pelado, porque non se cierre, et de sí dale buenas viandas, et escúsalo de trabajar fasta que la péñola venga nueua, et esto es en las péñolas mayores, que son en el lugar que es pobre de gouierno, si lo non esfuerças con buenas viandas que le des. Otrosí, si la péñola es quebrada en guisa que se rronpió todo lo maçiço et alguna cosa del cañon, pero fincó quanto la meytad del cañon, estonce tomarás otra tal péñola de otra aue como la has menester para ally; si cuchillo, cuchillo, si tijera, tijera; et faz mucho que sea del plumaje de la su aue, ca non deues enxerir al girifalte péñola de nebly, nin al nebly de girifalte, ca non se faria bien, mas á cada aue buscar péñola semejante, et si es pollo faz mucho que sea la péñola que as de enxerir polla, et si mudado, mudada; estonçe toma el cuchillo que falleçe, et yguálalo con la péñola quebrada do se ha de enxerir, et conciértalo bien con ella, et sea de aquella et de tal ala como fallesce, si es ysquierda, sea del ala ysquierda, et si derecha, sea del ala derecha; et de aquel cuento del logar si es cuchillo primero, ó segundo et dende adelante, et toma la tal péñola et córtala por el cañon, en guisa que quando entrare por el otro cañon llegue fasta cerca de lo biuo, mas non llegue á ello, porque le non duela, et fiéndole la péñola que traes de fuera por el cañon á luengo, et sácale aquel meollo que trae de dentro, et ponle de la trementina vn poco, et entonçe, métela por el cañon del aue segund dicho hé. Et por quanto, como dicho hé, el cañon fincó corto, et la péñola que enxirıeres non toma 
tan grand asentamiento que pueda estar firme si el aue rebolease con vna presion, ó se debatiese, que luego la derribaria, et para que esté firme forada con vn alesna muy delgada, trayéndola como para fuso, aquellos dos cañones que están juntos en dos lugares en esta guisa: et por aquellos dos forados mete sendas plumas de perdiz, de las que traen en las alas, et corta la cola, porque son correosas, et non quebrantan, et mételas primero del floxel que tiene, et desque las metieres fasta que atiesten, córtagelas de cada cabo á rrays del cañon con vn cañiuete muy agudo.

I Otrosí, si la péñola fuere quebrada entre el cañon et lo maçiço, en guisa que todo el cañon finca entero, entonçes tomarás la péñola que traes para poner, et faz della como auemos dicho, et úntala con la trementina et metiéndola por el otro cañon del aue, en guisa que le encorpore bien vna en otra, et tal como está non ha menester tarugos, ca ella entra tanto por el cañon del aue, que estará asaz firme. Et guisa que sienpre, quando metieres estas péñolas por las otras, que entre retorçida et encogido el cañon de las péñolas que traes, porque non fagas rebentar á la péñola del aue, ca despues que dentro fuer allá se soltará et fenchirá todo el cañon, et por ende la fiende; lo primero, porque tome mejor la tremen tina, lo segundo, porque la apreta ome. Otrosí, si la péñola ó pluma es quebrantada por lo maçiço, por qualquier logar que sea quebrada, ó por lo más delgado, ó por lo más grueso, taja lo que estouiere marrotado, et toma la otra péñola que traes, et conçierta las péñolas en

I El MS. B. hace de este párrafo capítulo aparte. 
I $6 \mathrm{I}$

guisa que vengan nin más nin ménos de lo que han menester, et taja las dos péñolas, tanbien la del aue, como la que traes sosquinada por esta guisa.

Ca se junta mejor, en guisa que les non cortes las plumas menudillas de qualquier de las péñolas, cerca del logar do han de ser juntadas, ca pareçerian feas et non se encubriria bien la enxeridura. Et faz aquella cortadura de aquellas péñolas con gañinete bien agudo, et moja las dos péñolas en el lugar donde se han de enxerir con agua tibia, porque enternescan, et desí toma la aguja de enxerir, que sea fecha así: I

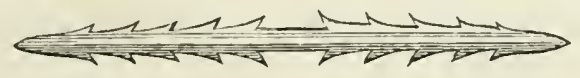

et estas agujas han de ser bien delgadas, et las vnas más gruesas que las otras, et otras de las pequeñas segund cada vna de las péñolas que se han de enxerir se rrequiere, et son todas de tres esquinas de cabo á cabo de las puntas fasta el medio, et tenga sus esquinillas leuantadas al reués las vnas de las otras, porque entre la péñola et despues non pueda salir. Pero estas picaduras del aguja non sean muy espesas, et bien te digo que pocas vezes las falla ome que les cunplen, por ende do las fallares tómalas et guárdalas bien, et sean bien fechas, las esquinas non sean muy luengas,

\& Ei grahado representa la aguja de enjerir, en tamaño bastante mayor del natural. 


\section{2}

et sean tan grandes et tan gruesas como pertenesçen en el logar do han de estar, en guisa que non rrebiente la péñola, et con aquella aguja mojada en la sal et agua, porque orinesca, junta las péñolas vna con otra, et faz que entre tanto el aguja en la vna péñola como en la otra, et se venga á juntar en medio del aguja. En todas estas cosas para mientes de lo fazer bien con buen tiento, que non enxieras torçido nin fuera de medida, et la péñola si lo bien fezieres pocos deuisarán si es enxerida, et para esto sienpre anda aperçibido de buenas agujas mayores et menores, delgadas et gruesas, et de péñolas, cuchillos et tijeras, que los trayas contigo quando andovieres en el ynuierno á la caça, porque si menester fuese que le pongas luego rremedio. Otrosí, por estas ocasiones que vienen de se quebrar así las péñolas, sienpre deues catar et regir tu falcon quando alguna péńola se tuerçe, si vieres que non há otra liuor en ella, saluo torçedura, toma el agua caliente poco más que tibia, et mójala, et desque vieres que enternesçe traégela quedo con los dedos endresçando, et despues el aue misma la ha de adresçar con el pico, et si por ventura ouiere en ella liuor, que quiere dezir quebrantadura, porque non es la péñola partida, toma entonçe vn troncho de verça de col, ó la foja penca, et si es gruesa ponla en el rescoldo, et desque fuer caliente sácala et ábrela, et toma entre ella aquella quebradura de la péñola, et ténla ally vna pieça fasta que suelde, et ally luego soldará. 


\section{CAPITULO XLVII.}

DE CuÁles cosas et melezinas deue aNdar aperÇibido EL CAÇADOR ET traER CONSIGo para sus aues.

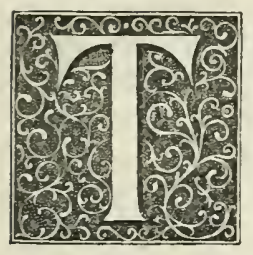

ODO caçador deue ser muy apostado en sus aues, ca pues lo toma para auer plazer, et faze costa en buscar et conprar nobles falcones, deue eso mismo traerlos bien guarnidos et bien apostados, et para esto deue andar bien aperçebido de traer buenos capirotes, et bien fechos, et de todas guisas, grandes et menores, así para girifaltes como para neblís, açores et otros falcones, ca cada aue há la cabeça á su talle, porque ha menester capirote á su façion; et deue traer cuero bueno para los fazer, et el mejor cuero que en el mundo ay para ellos son buenos cueros de bezerros que traen de francia, que llaman cueros de abadía, et dízenlos así porque los monjes de las abadías dizen que los adoban para sus çapatos et para sus botas. Otrosí, deue el caçador traer muchas piuclas et siñuelos 
liuianos, luas, lonjas, atanbor, cascaueles de milana doblados, grandes, menores et pequeños, tornillos para açores et gauilanes, ferramental del menester de los falcones, en que hay torquesas, buen gañiuete, punçon para coser, señuelo, cuchillo para tajar los capirotes et piuelas, los fierros para labrar, segund suso están figurados, lima para adobar las formas de los capirotes, cada rna de su guisa, cordeles para señolar. Et cada falconero deue traer sus gañiuetes muy grandes para aparejar la vianda de su falcon, et fazer juntas et plumadas. Otrosí, deue traer sus pequeñas linjaueras de lienço bien fechas para traer al costado, do acorra á meter et á esconder et cobrar el ánade, ó la rralea quel falcon tomare porque la non vea, et do traya la vianda para su falcon, et sus roederos et el capirote sobrado et los cascaueles, si quiere cargar ó descargar su falcon, et deue traer vna linjauera grande, do traya sus gallinas muertas, et plumas et roederos, et sus viandas para quando han de dar de comer á sus falcones. Otrosí, deue tracr vnas que llaman caxeras; que se fazen de barua de ballena, fechas desta guisa:

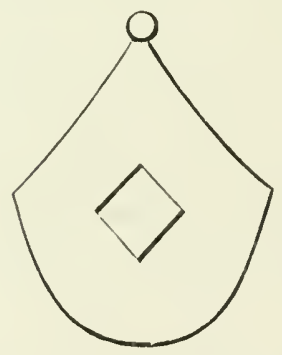

ó las fazen de madera, que son para traer gallina biua, que non se afogue, porque pueda acorrer á su falcon si viere que lo non puede cojer, et non trae presion que le echen, et lo ree yr á perder por miedo de águila. Otrosí, deue de andar apercebido el caçador de traer consigo melezinas para sus aues, las quales son estas:

Buena mumia, que es la más preçiosa melezina para los quebrantamientos del falcon, que puede seer et es fe- 
cha de carne de ome conficionada, et lo mejor della es la cabeça.

Azaragatona que tienen los buticarios.

Simiente de mestuerço.

Pez luziente et vírgen.

Simiente de perexil.

Azéche.

Casca de enzina.

Çumaque.

Suelda de raca.

Sangre de drago.

Azéuar çecotrí.

Azéuar pátigo.

Bolarmenico.

Miel dura en terron.

Ençienso.

Nuez de india.

Nuez moscada.

Maçis.

Açúcar blanco.

Açúcar candy.

Açafran.

Yerua golondrina.

C.umo de condeso.

Delante dirémos qué es pinpinilla, bursa pastoris, yerua golondrina todo es uno.

Coral blanco.

Cardenillo, otros lo llaman verdet.

Alunbre, otros lo llaman alume.

Almástica.

Piedra sanguínea.

Clauos de girofre.

Cañcla. 
Flor de cañela.

Espic.

Aceyte.

Aluayalde.

Enxundia de garça.

Dialtea.

Unguento çetrino.

Alcatenis.

Leche de cabras.

Mirra.

Estopas de seda.

Fauarraz.

Tártago.

Buenas tijeras para trasquilar plumas.

Vn peso pequeño para las espeçias pesar.

Lançetas.

Agujas de enxerir.

Agujas para coser ferida.

Píldoras de açyuar çecotri, son buenas para purgamiento del cucrpo, et fallarás en el capítulo xi cómo se fazen.

Simiente de yerua menudilla.

Çumo de finojo.

Alosna, que es ençienso amargo.

Xabon françés.

Trementina.

Çenisa de vides.

Seuo de carnero.

Suelda para feridas del falcon, et en poluos, et fallarla as cómo se deue fazer en el capítulo xxv.

Suelda que dan á los falcones en la vianda para los quebrantamientos del cuerpo, fallarás cómo se deue fazer en el capítulo xxviı. 


$$
167
$$

Agua de espic, que es buena para el falcon que tiene comienço de agua vedriada, fallarla as en el capítulo xi.

Poluos para quando el falcon regita fallarás en el capítulo xxxill.

Condeso es vna mata que tiene la foja menudilla, como trébol, et el madero es como blanco, et dizen que con el madero dello que lo tuerçen et que atan en algunas tierras cubas con ello, et el çumo que mandan poner dél para las lonbrizes ha de seer de la rayz, et nasçe comunalmente en las rriberas del agua, et si non lo fallares aprouéchate de la yerua lonbriguera, ca esto era para las lonbrices.

Poluos para la vña del falcon en el capitulo xxvi lo fallarás, son buenos para feridas.

Aquí se acaba el libro de la caça de las aues, que fizo pero lopez de ayala en el castillo de ouiedes en portogal, en el mes de junio, año del

Señor de mill et trezientos et ochenta

y seys años, era de çésar de mccccxxulı años. 



\section{GLOSA S}

DEL

DUQUE DE ALBURQUERQUE. 



\section{GLOSAS.}

Capítulo il.-Del falcon neblí.

Yo siempre fallé mejor el falcon negro que los aluos para las prisiones que rrestañan, y como dizen en esto de los falcones bondades vencen; y lo que miro á un falcon es que sea comedor y gastador y liuiano, $y$ huclgo mucho de que doi de comer á mi neblí, y aún á mi sacre si se me desala sobre la mano, y come como burniniego, que esto fasen de canines, y son muy buenos para prisiones ganadas. En tierra de la mi villa de ledesma tengo rn monte que se llama la cabeça, de do me traen neblís pollos negros y lo aluo aluo; nunca de allí tuve mal halcon. A mí me truxeron de alli vn neblí pollo, como dicho hé, dia de sant miguel, y traia las cerillas en el pico y las tolleduras en la ouera, del nido. Maté con él, dende á quinze dias que me lo truxeron milano brauo, desde vno hasta veinte y ocho, que nunca me erró milano.

\section{Capítulo iv.-Del gerifalte.}

El gerifalte querria yo que fuese sacado y derecho, y el pico pequeño y los ojos enconados y las manos gruesas y cortas, y no cosquilloso, y con bucina vista y el más çahareño $y$ esquiuo que pudiese ser para le auer de fazer, 
Capítulo v.-Del falcon sacre.

El sacre querríale yo largo de alas y de cola, el pescueso grueso, los ojos enconados, el pico pequeño y derecho, y que comiese de la manera que ya he dicho en el capítulo 11 , desalado como burniniego, y destos tales he fecho marauillosos milaneros.

\section{Capítulo vi.-Del borní.}

Estos bornís es buen linaje de falcones, porque son poco costosos para los fidalgos que no pueden caçar con otras aues, y avn ayúdales á la costa de la carne; aunque yo ya tuue borní garcero y buen lechucero, y ví otro á rui dias de mendoça que mataua quebranta hueso.

Capítulo viı.-De los alfaneques.

Con estos alfaneques nunca curé de caçar mucho, porque con viento buelan poco, y con sol rodean mucho, aunque algunos dellos son buenos lebreros y perdigueros y picaçeros, y yo ví vno al duque de alua, que era garcero.

\section{Capítulo vili.-De cómo se a de regir y gouernar el falcon neblí.}

Como yo mando faser los neblíes, es en esta manera: traémele el redero cosidos los ojos, y así le fago muy bien guarnecer, cortar el pico y las vñas y poner el capirote sobre los ojos cosidos, y ponérsele y quitárscle tantas veses á que él se fase al dicho capirote y pierde la congoja dél; y desque abaxa el pico á comer en la mano, 


\section{3}

fágole descoser los ojos y rociárselos con vino blanco fino, y mando que el caçador traya vn sainete y se aparte con él á lo oscuro en cábo de una sala, y le quite el capirote y le dé de aquel sainete, por manera que pierda el miedo del rostro del caçador. Y desque esto tengo fecho y ya el falcon come sin capirote, si es pollo de las rocinas, ó del campo de sanctaren, ó del monte de la cabeça quando he de cenar, mando que se ponga el caçador de piés en el vanco donde yo estoi asentado, $y$ tenga el falcon sin capirote con un rocdero en la mano, porque rea el bollicio del seruir de la mesa y los pajes y hachas que á la mesa llegan, y despues mándole madrugar no más de quanto quiere rreir el alua, y que todo aquel tiempo fasta que es claro el caçador esté en el campo ó á rentana fasia do viene el alua, porque el falcon dé á las alas y reconosca el campo, y reconosca que está en la mano del caçador. Y luego que esto fase, fágole muy manero, faciéndole saltar de rna mano á otra, porque aún esto es muy bueno para asegurarle más, y tambien póngole en el suelo y yo en pié fágole subir á la mano, porque aun esto es muy bueno, porque cada rezque tu falcon cae con prision ó al señuelo cae en el suclo, y si el falcon es resabioso, si te ue venir en pié al coger, ó por bien que te abaxes, siempre toma más resabio, y desque está vsado de subir del suelo á la mano, pierde toda la sombra y resabio que puede tener. Y despues desto fágole saltar sobre el senuelo encarnado, y despues más alargo con cordel, y desque ya va bien, fágole degollar gallinas, que mientras las degüella ande el caçador con vn guante dándole vozes en derredor y golpes en su pierna, encendiéndolo y enritándolo. Esto há dos prouechos: la una (sic) que pierde el miedo del caçador y se aseguran; la otra, que reconoce la ros quando alguna ves se pierde ó anda en el aire, y piensa que le quieren dar de comer, y do quicra que le oye sale al caçador, y cae al señuelo ó á gallina. Y desque veo que mi neblí está ya desta manera, y que desque le quita el caçador el capirote non le mira al rrostro, ni al que anda, si no á la mano, si este falcon quiero faser garcero, échole vna garça muerta caliente, de la mano al suclo, y menéogela, y pela é céuole en ella, y dendeá 
dos dias échole otra á la boca de la noche con buena hambre, cosidos los ojos, é céuole bien en ella de cañadas, é fásele plaser. Y no le doi más á comer de la garça de quanto puedo pensar quel papo le llegará fasta la media noche, y dende á tercero dia lánçole en compañía del maestro á otra garça, de que anda de caida en caida. E á la tercera garça échole más alto, é de allí adelante sólo por sí, porque se.... I sobir á lo alto fasta que sepa matar rremontado. Es marauilla de los falcones de la cabeça, que vna gentilesa fallé más en ellos que en ninguno de otra parte, que sin le templar, dándole oy vn miembro y miembro y medio de gallina mañana, mata la garça, ó qualquiera otra prision por alta que sea. A mí me acontesió con el neblí milanero que he dicho en el capítulo II, que le mandé dar vn dia de mañana en mi cámara vna tetilla de gallina, é de que fué medio dia, teníala gastada, é desque su caçador vino á la tarde non le dixo mi camarero que auia comido, y entró en la cosina y dióle dies y ocho coraçones de gallina, y otro dia de mañana mató vn milano de los más altos que nunca ví. Digo esto, por la gentilesa de los falcones de la cabeça. E si le quiero faser altanero, mando rebolarle é darle vina buclta por cima de la laguna, y dalle señuelo, y que degüelle vna gallina encima dél, y le den allí de comer vn miembro della y el coraçon. Otro dia mando tomar vn lauanco biuo aguado, é mándole rebolar con el maestro vna buelta y lançarle el dicho lauanco biuo debaxo; y céuole en los pechos y el coraçon y la lengua por sainete despues que se sacude ó tulle en la mano, é otro dia que tome el agua, y de allí adelante que buele con el maestro, puesto que en la cetrería ponen estos dos buelos de garça y altanería por reales, y yo por tales los tengo; mas en muy poco tengo faser vn neblí garcero ni altanero, que son viandas dulces y fechas á comer dellas á su naturalesa. En lo que yo doi gracias á mi caçador es quando face que mi neblí mate milano, lechusa ó darda vasin, ó buarro açoreno ó grua, ó abutardas, que las vnas destas raleas de grana-

I Parece decir vese. 


\section{5}

das las otras que rescuñan mucho, é son fuera de la naturaleza del seuarse del neblí, fasérselas matar el caçador, aquel tal merece gracias. Si mi falcon toma cuerua ó corneja, y troca la prision por ella, quítagela, como dise en el libro. Dende á vn ora lánçole de mi voluntad á otra, y sácogela, poniéndole el capirote sin le dar picada en ella y luego lánçole á otra, y sei cierto que las aborrecerá para que nunca más vaya á ellas. Otra experiencia muy cierta para los falcones que se toman me dixo don luis de yxar, fijo del conde de aliaga en aragon, que de que sus falcones se tomauan, que los tomaua por anbos los çancos juntos, y los metia quatro ó cinco veses debaxo del agua, y nunca más se tomauan: yo así lo fago siempre á mis falcones despues acá, y nunca más se toman. La costumbre que yo tengo es mandar dar bien de comer á mis falcones de que se fazen, y algunos caçadores veo que los abaxan por fasellos señoleros. Veo éste yerro, que despues que lo suben en las prisiones y volando yerra la prision, desaman el señuelo, no conoscen el caçador, son muy malos de coger, ó se pierden; y por esto con la carne que traen del campo los mando faser al señuelo, y quantos regalos yo puedo sobre el señuelo, porque sean querenciosos dél y de su caçador; y antes te digo que me atreuo á baxallos vn poco para el matar de las prisiones que no al facerlos señoleros, aunque mi costumbre es caçar con aues muy gruesas, porque buelan con furia y resio, y suben á do los mandais por las prisiones, $\mathrm{y}$ aún sufre mejor qualquier grande temple que les querais dar que si andan baxas: y en conclusion, yo quiero más que se pierda mi falcon gordo, que non que no alcance la prision por flaqueza, ó se muera en poder del caçador. Hago que mi falcon, desque se toma fasta que vuela, no aya más de reinte ó veinticinco dias, porque de allí adelante todo es enbobecerse y perderse el falcon. $\mathrm{Y}$ en esto que dise en el libro que esté toda la noche candela con su falcon, yo lo proué y estoi cierto el falcon non gasta tanto con vela toda la noche como ascuras. Basta tener á vn falcon despues de puesto en su vara dos ó tres oras vna vela ó candela delante ardiendo, porque se pueda á ella curar y alçar si quiere, y quítensela despues, 
que cierto soi que gastará más el papo que si la tuviese fasta la mañana, porque ya lo experimenté. La manera que mando tener con el falcon maestro mio, es ponelle en anochesiendo en su vara, y non le madrugar más de quanto enpieça á esclarecer, y que entonces lo tome el caçador en la mano y le traiga fasta que faga la pluma y la babada, y se ponga vn rrato en rna piedra al sol, ó en prado, ó campo, ó en verja, que vea el cielo fasta que faga la babada, y si aquel dia ha de caçar á la tarde, que le dé de roer y picadas, y si ha de caçar luego, que no le dé nada, no sea si quisiere roer en pico ala de gallina, $y$ no en cola de carnero, esto por la costumbre de la pluma, que por la codicia del roer, ó esperando que les ha de dar del roer en la mañana la fase luego temprano. Toda el administracion del falcon, así para amansalle, como para facerle caçar, ó para le melecinar y atajar dolencias, va en el buen caçador, que los caçadores son de dos maneras: la vna que caçan por complaser á los señores, y porque les dan por allí de comer, y á estos tales les adoiecen los falcones, y los tienen desabridos y destemplados, y, nunca para bien caçar: ay otros caçadores que caçan á calidad y á condicion; estos son muy querenciosos de las aues, trauajan mucho con ellas, así en caçar en mal tiempo ó en buen tiempo, y en viandar su falcon y en milicinalle y regille con mucho amor; que caçador tube yo que si se le moria ó perdia su falcon, asílloraua por él como si se le muriera vn hijo. Deue conoçer el señor la condicion de los cacadores, y así facerles honra, y darles de comer, y fiar dellos los falcones fermosos de que se espera que lo an de faser bien. Ca sei cierto que si el buen falcon toma caçador de condicion, que sea caçador, que muy más ayna fará que mate su falcon, y mejor que no el otro caçador que á naturaleza no es caçador, y guarda que el caçador sea paciente y non mal enconioso ni soberbio con su falcon, que muy grande defecto es al caçador ser desta condicion, que ser vn falcon quexoso ó mal capirotero, mira que es aquella su condicion, porque no entienden más, y la discrecion del caçador que entiende le ha de sofrir aquello, y halagar y comportar aquello, porque mientra más soberbiamente el caçador le trata- 


\section{7}

re, tanto más brauo le fará. Ca yo tube caçador desta condicion soberbia que cada vez que yua á coger su falcon, se quexaua como vn niño de que su maestro le faze mal, y con otro qualquier que le cogia se halagaua y esperaua y se dexaua tomar. Para el falcon esquivo de poner el capirote ví faser vna experiencia á vin caçador del rey de francia, que se llamaua felipe delcon, que colgaua vn jarro de agua encima de sí y del falcon, y fora dábale por el suelo, de manera que salia gota á gota el agua, é poníase debaxo por vía que diesen aquellas gotas en la cabeça é pico del falcon, y así como le dauan las gotas del agua encogia el falcon la cabeça, é poníale y quitábale el capirote. Era vn girifalte muy fermoso que traia, y sin dubda le esperaua el capirote quantas vesesquerria, teniéndole de esta manera. Muchas opiniones hay en los caçadores, y pues que los que son caçadores las vsan, no dúdo ser buenas; mas yo lo que fago á mi falcon, de que es mal capirotero, es mansamente con sainete y roedero halagalle, y quitársele y ponérsele lo más mansamente que puedo, y aún es bueno ponelle vn capirote ancho, blando y de cerraderos, por manera que al poner y quitar no sienta enojo alguno, y así se asegura mucho, y despues que esté bien asegurado tórnalle el capirote que ha de traer para caçar; y asimismo tengo esta manera al salir mi falcon de la muda, que es acabado de sainar y, es recordado en el señuelo; ó desque le saco del arco ó de poder del redero y es fecho señolero, por muy seguro y rrepreso que le tengan el señuelo en degollar gallinas, el primer lançe que le he dechar á prision échole con maestro, como he dicho, que non la yerre, que el muy señolero maestro sea, porque á dos veses que viene á la prision, si non pega con ella, mándoles dar señuelo, y que estén los caçadores muy aperseuidos de gallinas y señuelos, porque si yerra la prision, en especial si es sacre, de que reconoscen el campo y se encienden en el buelo, muy malos son de coger, y así he perdido algunos falcones, y contentome con dos cosas: la vna en prouar que no toma, la otra en que torna al señuelo, que desque estas dos cosas tengo conocidas de mi falcon, él fáselle matar, he yo por lo de menos. Tengo esta manera di- 
cha porque yo auenturo mucho las aues en los buclos vistosos, no siendo tanto quando las pierdo, así como quando se pierde al empieço del salir del señuclo á la prision. E cata que mires en esto que mucho experimentándolo tengo por perdidas de falcones que he auido. E por esto administra tu falcon en los primeros buelos de la manera que aquí he dicho, porque en especial los falcones que vienen bouos del arco, y se rreconoseen en el primer buelo, muy malamente desconocen, y por esto ha de ser el maestro muy señolero, como he dicho, porque en dando al señuelo dexe la prision y caiga, y el aprendiz de que le uee caer con aquella codicia, cae tambien, y desta manera se asegura el perder de los falcones.

Caŕt́rulo 1x.-De cómo los deuen vañar del piojo.

Como yo mando vañar a mis alcones es echar onça y media de pimienta cernida y molida en seis azunbres de agua y medio azunbre de vino blanco, rrebuclta la dicha pimienta con esta agua y vino, y así los mando vañar. Pero si es falcon fermoso y aluo de plumaje, porque no se enturbie la pluma mándole dar el raño sacada la leche de la pimienta en el agua y vino, como en el capítulo lo dice; pero si el falcon está flaco, mándole dar el vaño desta manera : tomar dos onças de azogue y matallo con saliua de honbre en ayunas, y tomar de çumo de fojas de pristos ó de çumo de acelgas tanto como cabrá en medio casco de nuez, y rreboluerlo todo, y con aquello sotilmente vintar el alcon por todas las partes y debaxo de las plumas mientra el alcon come, porque lo esperará mejor, y despues rrocíalle con vino blanco fino caliente cuanto se pueda so fin en la boca, y tenello al sol ó á buena calor de brasero, y esto les matará y sacará el piojo, y es vaño seguro que non se atormenta ni se fatiga al falcon. El rey de francia me dixo que á sus falcones los mandaua dar el vaño de pimienta y ceniza de carrizo molido y cernido, cuatro partes de pimienta y vna de la 
dicha ceniza, y que con vna aguatocho ó seringa de platero los fasia poluorear mucho debaxo de las plumas por todas las partes de que le tenia en la mano del caçador su compañero bien poluorisa, de que lo fasia rrociar por ensima de la pluma, y por debaxo de las alas y por todo cabo con vino blanco fino al sol. E que esto fallaua él muy buen vaño, porque escusaba de derribar el falcon y de congoxalle rrecibiendo el raño de artesa. Ya he dicho en esta ğlosa quán dañoso y peligroso es á los alcones derriballos, y por esto me parece que llenarás con esto que el rey de francia me dixo, aunque yo no le he mandado prouar con seringa, saluo á los alcones que han enpesado á derribar y á nacer los cuchillos, y es necesario darles el vaño. Para asentar en la muda mando tomar el agua y vino con la leche de pimienta al caçador con la boca, aunque reciba trauajo, y mándagelo rrociar fasta que la pluma y el floxel todo esté empapado, y mándole despues poluorear con pimienta cernida por toda la pluma y rrociar por sima con lo ya dicho en la mano del caçador: y sin duda basta tanto para sacalle y matalle el piojo como en el artesa, y escúsase que non le derriba. En especial es muy buen vaño este para sacres y girifaltes, porque están acostumbrados á rrociarse con agua, y aunque los rrocian con el dicho vino y agua y pimienta, piensa que es con lo mismo que les suclen rrociar, y sufrenlo muy bien y aprouéchanles mucho.

Capítulo x.-Cómo se deue melesinar del agua.

Antes se deue dar á tirar y rroer porque traya el agua á las ventanas, y luego chuparlos y despues rrociarlos con agua aseda y ponelle en su vara y en la candela delante que se piense. Espique y flor de canela y canela es muy caliente, y láuale la carne en ello como dise en el capítulo. Si el agua es congelada de frialdad del buche deuésele iauar la carne con el agua destas cosas calientes, y si conociere el caçador que es de fenchimiento del buche y es calentamiento de la boca, aprouecharle á lavarle la 
carne que ha de comer con agua de la saragatona y agua rosada.

Capítulo xı.-Cómose deue melesinar del agua del brandimiento que desimos vedriada.

En donde dise del mijo ayúdale con rna parte de sal molida y ocho de mijo tostado ello y la sal, y la mayor parte désto cárgagelo en el colodrillo de medio atrás de la cabeça; y donde dise el talengonsillo de las rrosas sea capirote forrado en grana en valdrés muy blando y aún de cuernos, como los que traen en el arco. I entre la grana y el cuero échale las rrosas molidas bueltas con vnos granos de almisque molido y vn poco de linalve, y faser por otro cabo vn cosimiento de rrosas en muy fino vino blanco, y con esto tibio quanto lo pueda sofrir en la boca y rrociarle los ojos y la cabeça con este cosimiento de vino y rrosas, y un poco el capirote, y ponérgelo has muy caliente y en buena vara y cámara caliente si non viniere sol y si fisiere sol. Pero si fisiere sol y dia siguro, tenerlo has la sol en corredor abrigado donde no dé ayre, porque ponelle el saquete mojado en el cosimiento de las rrosas ya yo lo proué á alcones mios, en quanto duraua la calor del cosimiento aprouecháuale, y despues que aquel calor pasaua esfriáuanse. I aunque el cosimiento fuese de cosas calientes de causa de la vmidad de lo mojado del agua, esfriáles las cabecas y aún es causa de bedriárseles más el agua; yo aquello del capirote fallé mejor. I en esto que fabla de la píldora, bueno es, porque el acíbar tiene rrespeto contra el àgua. E la agua del finojo aclara la vista, mas lo que yo mando dar á mis falcones es la píldora que ya dixe en el capítulo 11 , por más ayudar y faser mejor obra que estas píldoras vidar y aprouechar por mucho loables y experimentadas á vn muy gran caçador que se llamaua lúcas alfonso, que era de esclauonia, de que fué criado en rroma del cardenal viçe canceller, que fué gran caçador con el rey don Alfon de nápoles, y despues vino en portugal y fué del rey de portugal. Estos materiales destas píldoras han de ser tres partes 
de acíbar y dos de almodaciles y dos de tornique y menos de vna parte de gengibre, y parte y media de garico y vnas hebras de açafran y un poco de açúcar piedra, esto todo amasado con triaca fina. I estas nueue píldoras que dise que sean de tres en tres dadas, se puede faser de la cantidad de cada tres vna y dárgela has en los dichos nueue dias, porque auiéndole de dar tres píldoras vna tras otra, auias de derribar el falcon, y auiéndole de dar vna píldora sola, puedes como que le alimpias el pico abrírsele con los dedos y echárgelo dentro. Estas píldoras es harto como vna auellana pequeña, y si la primera $y$ sigunda píldora viere el caçador que no descarga su alcon de la dicha agua, ayúdale á la otra píldora con peso de seis granos de trigo de ruibaruo y con peso de dos granos de trigo de espique rrebuelto con la masa de las dichas píldoras que dicho es. I si viere el caçador que esto no aprouecha, á la noche, teniendo gastado el falcon, dele bien de rroer y tirar, tórnelo á rrociar con el agua aseda otra ues, y otro dia dele de sacudir con fauarrás á buen sol, ó si non fisiere sol á buena calor de brasero, y así curarás tu falcon de manera que sea sano: por estas cosas yo las he mandado prouar en mis falcones y tengo dellas muchos experimentos, pero has de mirar que estas melesinas que le dieres que las des cuerdamente mirando tu falcon, qué es lo que cada dia muestra en la dicha dolencia, y así le rregirás y darle as en este tiempo de la cura cada dia de vna pierna de polla, segun fuere tu falcon ó vieres que la gasta, ó si la ha menester toda ó parte della, quitándole en este tiempo el escudete que junto con la cadera, que es carne muy dura de gastar. E cada ues que dieres vna de las dichas tres píldoras en los nueue dias, mirarás que desque el alcon aya tullido quatro ó cinco veses como le eches tanto açúcar piedra como vna aluellana ansí mansamente sin derribarle. E despues que tullere dos reses el açúcar, pruénle el agua y beua della quanta quisiere, y si la quisiere tomar dégengela tomar y non le den de comer fasta que tullere de lo suyo blanco. Entonces le darás de la dicha pierna de polla como dicho es. El dia de la purga non le des pluma, y otro dia por la mañana darle has rna pierna de gallina ca- 
liente para que tenga sustancia para conportar las dichas melesinas, y á la noche darle la pluma mojada en agua de sargatona y agua de endibia: esta sargatona se ha de echar desde la mañana á rremojar en el agua de endibia para mojarle la pluma á la noche, porque para el escalentamiento del buche es muy buena cosa, é si uieres que la complicion de tu falcon está flaca y déuilitada, dale la dicha píldora cosida en vn lensesico doblado que esto basta para le faser purgar seguramente.

Cipítulo xir.-Cómo se deuen faser las purgas para purgar los cuerpos de los falcones, y açores, y gauilanes.

En este capítulo deueis mucho mirar, porque en esto está mucho la salud de los alcones, y los más creo que se mueren dándoles purgas rresias, mayormente donde entra colocunda y esclamonia y diagrid, que esta tal medecina, aunque vaya muy preparada, nunca le quitarás su daño. I lo que principalmente haze es destruir el buche de todo punto y el fígado, y así enflaquecido y destruido luego sobrevienen muchas enfermedades de que mueren, y filomeras en especial, y porque esto yo tengo mucho mandado á mis caçadores que non den á mis falcones las tales purgas, sino que sean muy seguras, y estas no muchas veses, ni en mucha cantidad, porque aunque sean tales y alimpian, son como quien muchas veces laua vn paño, que aunque le tiene limpio muy ayna se rrompe, $y$ así fase á los falcones, aunque les alimpia enflaquecen la virtud, por donde vienen otras enfermedades peores. I por esto yo mando que los conceruen desta manera; aun podiamos dezir que es muy ympropio á la calidad del agua esta forma de melesinar, por cuanto él es engendrado en hueuo y criado á carnes crudas. Todas estas melesinas son las que vemos que los físicos naturalmente curan los hombres que son nacidos y criados de otra propiedad que los alcones. Pero como ya dixe, los caçadores apasionadamente como yo soi, quisieron tomar vin consuelo de medecinar, que es tener alguna esperança fasta 
la muerte del falcon, y tambien non es de dudar en las melesinas, porque como las fallaron experimentaron los sábios pasados para curar los hombres, así me consuelo yo como por los honrrados caçadores pasados y presentes se han fallado tales experimentos, que aplicándolos bien y mansamente preparados los materiales aprouechen á los falcones, y por eso digo que ningun caçador desespere de curar su alcon por grande enfermedad que le venga, que aunque á mí se me han muerto algunos falcones, marauillosas curas he fecho en otros, y por escusar de no venir á este término con el alcon, darle as de comer de buenas viandas, en especial de pluma, así gallinas como palomas, lauanco, cerceta, garça, lechusa gorda, mesurándole el papo, como ya te dixe en esta glosa, que le llegue fasta las diez antes de la media noche, ó quando más á la media noche, porque desde allí fasta que le des otro dia de comer tenga tullido lo del buche y las tripas, que muy sano le será, como te dixe que no alcançe lo crudo á lo indixesto. E mando madrugar mi alcon quando quiere empesar á rreir el alua, y traelle en la mano y ponelle en vna piedra ó palo en el campo, de la manera de que él fase quando toma el atalaya en el campo. E cuando ha fecho la pluma y la bauada mándole dar á rroer, y si ese dia non ha de caçar, darle señuelo y dalle de comer, pero si niebla fase mando que non le saque á la niebla y que el caçador le traya en la mano dentro en casa, y mando ponerle despues que anochese media ora en vara, porque esto es lo natural de que él vsa en el campo, aluergarse temprano y madrugar de mañana. Esi el dicho alcon viene de caça mojado ó con nicbla ó yelo, mándole enxugar ó escalentar á una chimenea ó brasero, ó poner en buena vara firme y vn poco de vela delante á que se piense. Ha menester ser el caçador ser pasiente, como dixe, y creed que si el falcon' es bien tratado con paciencia de su caçador y gouernado y rregido de la manera que dicho hé, que pocas veces le habrás de melesinar, y esto es lo más sano para tu falcon. Cierto es que de todo lo que se come no puede así natura conuertir, mayormente si es algo demasiado, sin que dé algunas superfluidades que natura no las puede así rre- 
boluer y gastar; y por eso se dan las medecinas purgatiuas, porque el artificio ayude á la natura para lo así espeler, y si tu quieres conseruar bien tu alcon, mira la causa, y si la podieres rremediar ó que estas materias así demasiadas que ya dixe en este capítulo, non se alleguen, esto es lo mejor, lo qual puedes faser desta manera. Lo primero darle muy rregladamente de comer al alcon y madrugarle de contínuo, y despues de fecha la pluma fasle que rroya y tire con mucha fambre. E nota esto mucho que si bien lo sabes faser así cada dia, no ha menester otra cosa, pero si todavía fuere menester purgarle algo, mando yo á mis caçadores que non le den si non está; quando le quisieres purgar dale vn dia antes granos de gallo cresta así enteros, y dende arrato dale de comer, $\mathrm{y}$ despues dale vna píldora destas que se siguen: acibar çicotri dos escúpulos, mirra vn escúpulo, que es peso de veinte granos de trigo, açafran peso de dies granos, ga rico fino vn escúpulo, anís, cortesa de mirabolanos cetrinos de cada rno peso de quince granos, ruy pontico tanto como la meytad del todo sea fecho poluos y amasado con çumo de açenjos ó de finojo, y sean fechas píldoras como garuanços, tomen dellas vna ó tres, como uieren que cumple. Nota asimesmo que vale más purgarle en tres veses ó en dos más que en vna, y esto tengo yo mucho prouado y siempre ví los falcones estar buenos con este rregimiento, y por escusar estas purgas á que como aquí digo fuí siempre mal deuoto en el dicho rregimiento de mis falcones, mando tener en esta manera si por causa de ceuar tarde non dan pluma á mi falcon y non se escusa que él non lleue algun floxel de la garça ó del milano aunque el caçador lo quiera guardar, mándole echar en la mañana antes que coma tres troçicos de ciridueña mojado en aseite, porque con esto fase antes la bauada y echa el dicho floxel y alguna agua si en el buche le queda de causa de quedar sin pluma, y es muy bueno y muy seguro esto para alimpiar los alcones. I asimismo porque algunas vezes, así como en el paso ó en tierra que ay mucha caça, se ceuan cada dia los falcones y de causa de comer demasiado, finchen los buches y las tripas de que crian vmor demasiado, mando dar de dies á dies dias á 
mis falcones en pluma del pescueso de la gallina alquitira molida, saragatona en grano, partes yguales y volver con ellos tanto $\mathrm{y}$ medio de alholuas, y quando lleua la pluma mojada en la carnasa del pescueso, mándogelo dar á mi falcon, esto desde el mes de noviembre fasta mediado febrero, y de mediado febrero fasta que dan nudo mándole quitar de la parte y media de alholuas de la ina parte y que quede la media con la dicha alquitira y zargatona; $\mathrm{y}$ aún si fase mucha calor, como suele faser en abril y mayo, mándole mojar la pluma en agua de endivia; esto es muy seguro para desbuchar los alcones, y se puede dar esta noche y caçar otro'dia. O otra cosa mando dar á mis falcones; de quinse á quinse dias fago tomar rnos poluos de turbique y armodatil y alquitira molida y acíbar çicotri y garico y açúcar piedra y espiquenarde, de todo partes yguales $y$ vn grano de rruibaruo y vn poco de açafran y tanto gengifre como vn grano de trigo, y todo molido y revuelto, y mando tomar tantos poluos destos quantos cabe en tres dedos y que los echen en vna pluma de lienço, y cosella por manera que lion se pueda desatar y que non tenga más de in doblés de lienço, y mira que sea bien envuelta y cosida, porque los poluos non salgan del lienço, que le haria purgar demasiado, que los humos y virtud destas especias son suaues. E dárgela al alcon y sobre ella çinco ó seis picadas en vna pierna de gallina y con aquella pluma abaxa el agua de la cabeça y le esfuerça y alimpia el buche y corre las tripas y tiene mucho limpios los alcones y fázeles gana de comer. E otro dia fásela muy bien, y quando la fisiere dalle otras tres ó quatro picadas y bolar á la ora con él. E non has de dar esta pluma cl dia que seuares, sino el dia que dieres de comer de huelga, y non le darás menos de lo que acostumbras dar á tu alcon, saluo que ge lo des á tiempo, que quando le vengas á dar la pluma aya gastado antes in ora ó dos, lo que como y con estas cosas ya dichas, que yo tengo muy experimentadas, se escusa de dar purga ni píldora á mis falcones. 
C.apítulo xvir.-De cómo se deue melesinar de la enfermedad que tiene el papo lleno de viento.

Este palomo que dixe experimenté yo en paloma de las asules del palomar, porque son de complision más caliente, y has de dar con la dicha paloma estando ella biua vn gran golpe con ella de pechos en el suelo, por manera que se le venga allí la sangre y derrame por los pechos, y desta manera se la darás con su pluma y hueso, como en el capítulo dise.

Capítulo xvin.-De cómo los has de melesinar de las plumadas viejas.

Lo que yo trayo muy experimentado es echar vn palico de rrais de ciridueña del tamaño de vn piñon con cáscara mojado en ascite, que esté media ora en cl aseite, y échale tres pedaçuelos de aquello juntos, y esto les fase faser la pluma. I si esto no quisieres, vn grano de acíuar çicotri, y por esto no dexan de caçar, y para la pluma, que ya es algo gastada en las tripas, dale en dos dias tanta manteca fresca y lauada como vna nues, y dárgela as en ayunas y á la tarde vna pierna de polla.

\section{Capítulo xx.-De las lombrizes.}

Esta leche se da para convidar las lombrices que suelen venir á lo dulce para despues darles medecina que las mate ó las eche. E las medecinas que en esta tienen propriedad despues de auer tomado la leche, son las siguientes: tomen poluos de ajenxos vna parte y poluo de garisco media parte, farina de altramuses dos partes, y sea amasado y séale dado en forma de píldora. Asimismo es cosa muy prouechosa, toma la pluma de lançaron de la menuda y ponerla en horno á tostar fasta que se pue- 
da moler, de aquel poluo tomar media onça simiente de versas y verdulagas, de cada vno vna quarta, açafran media ochaua, sea todo mesclado y amasado con miel $y$ dado en forma de píldora, de manera que aya en esto quatro píldoras.

\section{Capítulo xxi.-De las filomeras.}

Desta enfermedad lo que yo tengo experimentado es el altemisa y enciencio verde y cudeso tanto de vno como de otro, y molido y sacado el sumo dello y echado en vna tripa de polla bien limpia y dado al alcon por la manana en ayunas. Este experimento hé yo por muy prouado que las mortifica. E antes dale vn coraçon de gallina envuelto en hebras de açafran, porque las filomeras salgan al olor y les tome más la melesina ya dicha. E si esta melesina no aprouechare, toma harina de alholuas y farina de altramuses y fojas de pristo molidas dos partes de las harinas y vna del poluo del pristo, y desfaserlas has con triaca y dárgelas as en manera de píldoras quatro ueses de tercero á tercero dia vna ves. E asimismo estas filomeras se suelen engendrar dexado de ser de su naturaleza y tracllas del campo, se suelen acrecentaró abiuar con los grandes temples que da el caçador á su falcon en tiempos frios ó de noches largas, y por esto te guardarás de dexar el falcon sin buenas picadas y pluma $\mathrm{y}$ gueso. E quando en las señas ya dichas vieres que tu falcon las tiene abiuadas, guárdate de purgarle mucho y con purga rresia, porque tanto quanto más se les saca el vmor más aina llegan las filomeras al coraçon y matan.

Capítulo xxir.-De la piedra que se cria en el buche.

A esto darle al falcon tres ó quatro dias de comer en carne de gallina ó en coraçon de puerco caliente, con la simiente de perexil en grano, y si esto no aprouechare toma 
centeno grana y simiente de perexil y pinpanilla partes yguales y de açúcar piedra tanto como la meitad de todo, muélelo todo junto y ciérnelo y amásalo con agua de abrojos ó de hortigas y fas tres píldoras tamañas como garuanços, $y$ dáselas de tercero en tercero dia en ayu-nas. I si esto no aprouechare, toma vn güevo fresco y apártale muy bien la clara de la yema y bate muy bien la dicha clara muchas ueses en vna escudilla con vina cuchara de plata y alímpiale siempre el espuma y fase ensima fasta que quede en agua sin faser espuma, y moja la carne que le han de dar de comer, y desto le darás á comer tres dias. I si con esto no se les desatare la piedra y la lançara, derriba muy mansamente el alcon y láuale con agua tiuia el cieço y sácale aquella piedra lo más mansamente que podieres con los dedos, y poncrle as por el cieço tres mechuelas de tosino aniejo muy lauadas del tamaño de vna almendra pequeña, y pónganselo dentro con vnas pinsas y así sanará deste mal, que yo lo he experimentado y es cosa muy cierta. Asimismo es muy buen experimento vntarles el cieço con aseite de alacranes caliente, cada dia dos veses. Éste derribar de los falcones es cosa que mucho les congoxa, el que los tiene como tenga dies dedos en las manos algunas veses aprieta más in dedo que otro, en especial si es sobre las costillas; por poco que se suma vna costilla fasia dentro trae á la muerte al falcon, y, por esto derribarle has teniéndole en la mano rrevoluiéndole vnas fasalejas de lienço, porque el alcon rreciba menos congoxa, y así se deué de faser en todas las otras curas en que cumpla estar derribado el falcon algun rrato.

\section{Capítulo xxin. - De la llaga afistolada.}

Lo que yo mando faser es cauterios atuales, como en el libro dise, porque esta cura esfuerça el miembro y cura la fístola, y todas las otras medisinas fuertes así como cáusticos potenciales enflaquecen y atraen más, pero despues de dado el fuego mando que non pongan aseite si- 
non manteca de vacas, porque esto derriba la escara y' mitiga dolores. I á otro dia ponle vna yema de hueuo batida con otro tanto de manteca de vacas, y esto puesto dos veses al dia. I despues de caida el escara ponle este vngüiento en vn panesico, toma miel rrosado y trementina, de cada vno vna onça, mirra y poluo de acenjos y encienso y arrostologra redonda de cada vno peso de vn quartillo de plata, sea todo encorporado á fuego manso, y cúralo con esto dos veses al dia y con esto se rremediará mucho y sanará muy ayna. Otro vngüento que tiene yntencion más á mundificar primero por quatro ó cinco dias despues de cayda la escara : toma miel rrosada tres onças, harina de ceuada muy sotilmente molida y cernida dos onças, harina de yeros onça y media; sean encorporadas las harinas con la miel y espesado al fuego manso á forma de vngüento. Con este vngüento lo curarás los cinco dias primeros. Despues séale añadido mirra, encienso menudo, sangre de drago, sarquecola de cada vno peso de in real sean molidos y cernidos y encorporado con la ya dicha. Laua primero la llaga con vna poca de agua ardiente, $y$ así se ha curado por esta forma y sanará.

Capítulo xxvi.-De los clauos que les nacen en meytad de las palmas.

Muchas ueses he auido esta platica con muy honrados caçadores del rey nuestro señor y con diego loarte, caçador mayor mio, y con mis caçadores que ellos tienen y dicen que estos clauos nacen de lás cosas dıchas en este capítulo de causas de los posos duros y cargamiento de carnes que les mastrujan las manos y les viene por esta causa clauos á ellas. Io estoy en que esto sea la menos causa, á lo qual me ayudaba manrreça, caçador del rey nuestro señor y el dicho lucas alfonso, que ya dixe en esta glosa. I la opinion que yo sostengo es que puesto que en las mudas pones poso duro al alcon, le pones sobre el tablado á lo menos tres dedos en alto el arena, y sierras la uentana y dexas ascuras tu falcon. Si el poso falla duro pó- 
nese en el arena, y aún si la quisiere échese en el poso ó en la dicha arena, y en su voluntad está del dicho falcon que á nadie non ve y nadie non le vea á él destar en el poso duro ó en el arena echado ó leuantado. I digo así que estos clauos se fasen de escalentamiento ó finchamiento del fígado ó de vmor malencónico en el buche, el qual se les causa que tú lleuas tu falcon en la mano, y porque él quiere bolar á prision que ve con el capirote, ó porque fase viento ó porque fase sol, ó porque el caçador corre con él en la mano á socorrer otro falcon ó ua perdido, y como el falcon quiere salir á qualquiera destas cosas de la mano, y el caçador pone todas sus fuerzas en la deuatida, y el caçador tiene y tira por las piguelas, de que rrescibe el falcón mucho enojo y quebrantamiento. Este derramamiento tórnasele en vmor malencónico, y desto fínchansele los piés y nácenle los clauos y más loueras en los girifaltes, porque son aues delicadas y muy congoxosas y aún porque sufren mal el capirote; y todas estas cosas ayudan al vmor malencónico. I quieres ver si es así, toma vn alcon brauo de seis mudas ó dende arriba del campo, que non duermen en poso lleno de borra ni de cuero, no trae las manos finchadas ni clauos en ellas, que si algo trae en las manos es andando en pos de las presiones, en especial, si es como cuerua ó tal que cosa que se les rrinde en espina ó garça, rrónpele las manos algun espina y de aquella le uerás mal, mas no clauos ni finchason como los que están en nuestro poder. I quicres más claro ver esto, pues que vn hombre gordo duerme en cama de colchones, y no está todo siempre sobre los piés, que es causa por qué á estos les viene gota ó piedra ó podraga en los dedos, y por aquí verás que es del mal vmor del estómago y del fígado por donde te conuiene purgar tu falcon en los tiempos que vieres que lo ha menester. I á tu girifalte darle as desde mediado março adelante vn poco de agua de endibia desatado en ello vn grano de rruibarbo y unas hebras de espique. I asimismo tratarás muy mansamente tu alcon, non dándole de batidas ni fasiendo con él soberuias, en especial guardarte as de correr con él trayendo el papo, que es cosa que mucho le dañará á la dicha enfermedad, porque 
acaece que este vmor non se purga así en el ticmpo deuido, como porque el caçador con su girifalte buela muchas liebras, y como los girifaltes dan grandes golpes y torpes á las liebras, viéneles ynchamiento á las manos, desta causa con lo ya dicho se pueden faser clauos, curárgelo as desta guisa. Darle as rna píldora de las ya dichas en la glosa del capítulo $1 \mathrm{v}$ del libro segundo, y despues para la jnchason de las manos tomarás rrosas secas y cáscaras de granadas anejas agallas de acipués, rn poco de cumaque en rasimo, cohollos de xara, simiente de arraigán. Esto todo cosido en vino tinto muy fino, $y$ lauarle as con este lauatorio, $y$ ponelle as de manos sobre vn patio mojado, y esto le gastará la dicha ynchason. $\mathrm{Y}$ si touiere soletas pónganle al henen del fecho en el vino del dicho lauatorio puesto debaxo y por sima de las manos, y con esto se les desfincharán las manos y caerse an las solctas por sí, y si touiere clauos toma goma armuyaca, serapi, galua, apopana, que de cada vno partes yguales, y echado en rremojo en vinagre muy fuerte de vn dia para otro. E despues derrama aquel vinagre $y$ échale otro vinagre muy fuerte tanta cantidad que se faga rngüento y cuega fasta que se faga espeso, y esto ponérselo as encima de los clauos tendido en vin valdrés ó vn cuero de vn guante y ponérselo as en las manos atado así como el capítulo dise, y esta melisina le sacará los clauos continuándose y bollirle as el clauo con la rña, porque la melisina aya logar de penetrarantes y sacárgelos. $\mathrm{E}$ despues de sacados los dichos clauos tomarás las dichas gomas y mesclarlas con poluo de lirio y di aquilon mayor tanto como cada rna de las partes de las dichas gomas, y ponérgelo as en las dichas llagas caliente quanto pueda sofrir el falcon, y con esto sanará. Asimismo es bueno para sacar los clauos las vaquillas vermégicas que se fasen en los maluares y májalas con sal, y ponérģelas as calientes sobre los dichos clauos y sacárgelos as en dos ó en tres dias que las tengan, poniéndoselas cada dia rna ves. Cada cosa desto mandé yo experimentar en alcones mios y es muy prouado. $\mathrm{E}$ porque muchas veses vemos alcones ser muy quexosos con papo, en especial con viento, $\mathrm{y}$ asimismo acontece ceuando, dar gran papo el caça- 
dor, y al sacar el alcon de la prision dale de batidas con el papo, y asimismo quedar perdido con la garça ó la prision y fállale con grande papo labrador ó quien no le sabe tratar. De cualquiera destas causas, el falcon rrecibe quebrantamiento, y gasta mal, y se les ynchan las tripas y queda con poca gana de comer. E de causa del quebrantamiento aquello que gasta mal conuiértesele en mal vmor. E desque el caçador ve que su alcon no quiere comer y piensa que es sólo de enbuchado, dale píldora, ó por ventura si piensa que es quebrantamiento dale sueldas. I si cuando le da la píldora cs más el quebrantamiento non le aprouecha y mátale. E si quando le da suelda es mal vmor, tanbien le fase poco prouecho. I en tal caso lo que yo mando dar á mis alcones es esto. Tomar alquitira molida y açúcar piedra molido y arsolla molida y saragatona en grano y mastuerço en grano, de todo partes yguales, todo mesclado y rrevuelto vno con otro. E si veo que la disposicion y conplision del alcon está resia, mándole dar aquesto en pluma de gallina tanto como se toma en los tres dedos. I si me parece que la conplision del falcon está develitada, mándogele dar en vna pluma de lienço sensillo cosida y elo experimentado muchas veses en mis alcones y fallo muy prouechoso, porque el alquitira y la saragatona tiene rrespeto á purgar y faser correr de las tripas, y el mastuerço y la arsolla á soldar y faser purgar sangre quebrada y quitar dolor. I por esto en tales casos lo mando administrar á mis falcones, y lo fallo muy prouechoso y seguro para cllos.

Capítulo xxxi.-De cómo los han de melesinar de la edropesía.

Este abrir de los falcones yo lo abria por muy peligroso, así porque coger las aues como es dicho quan peligroso es por la mucha congoxa que rrescibe y despues desto auerse de abrir tan cerca de las tripas, por muy poco que el falcon se bulla puede ser que obre más la lanceta de lo que querrias, rronperia las tripas. E como yo mandé curar vn falcon mio que fué tan grande gar-. 


\section{$19^{3}$}

cero, fué con vna yerua que se llama cardo vendito y con la yerua bretónica, tanto de rno como de otro, fecho en poluo amasado con triaca, $\mathrm{y}$ dale de tres en tres dias vna píldora, por manera que sea en nueue dias tres, $\mathrm{y}$ désele en ayunas, $\mathrm{y}$ esto le fará salir el agua, y dalle despues vn poco de açúcar y proualle su agua y dalle bien de comer de gallina tierna y caliente, y esto le sanará. I si esto non le aprouechare, tomarás cl sumo de rrais de lirio clarificado quantía de media auellana, y mesclarás con ello vnas hebritas de espiquenarde y otro poco de poluo de yerua buena y vn poco de alquetira molida, y desto poco fecho vna masa y fechas tres píldoras, cada vna tamaño como media auellana, y dárgelas has en ayunas de tercero á tercero dia, y dalle despues su acúcar y proualle su agua, y tres oras despues de dada la píldora dale de comer. I cuando esto les fisieres trasquílales como dise en este capítulo del libro, úntaselo con miel tiuia y polvoréale con flor de mançanilla y estiércol de cabras y de palomas, tanto de vno como de otro, vna ues cada dia mientras así le curares, y esto le sanará. I en cuanto á lo del beuer de los falcones, yo lo fallo muy prouechoso en esta guisa; que el dia que templan un falcon matar prision gruesa en que es por fuerça de darle bien de comer, y si non se falla la dicha prision aquel dia para bolar, es por fuerça así por el tiempo frio como por el tenple rresio de dalle bien de comer; y como el alcon tiene el buche encogido y ensangustido, y despues entra en él mucha vianda, árdele y cuese de manera como la olla desque se desmengua; aquellos vapores del buche súbenle á la cabeça y á la boca y escaliéntasele y fácenseles güermeses, $y$ por esto digo que es muy necesario si matan prision á la noche, dalle las cañas en agua despues que aya pelado vn poco en el ala de la dicha prision para que tuerça y dele al papo, $\mathrm{y}$ luego beua quantas veses quisiere con las cañas. É si non matare prision y le dieres bien de comer, así como he dicho, pele en un ala de gallina y échale las coradillas de la dicha gallina muy lauadas y desmenusadas en el agua, porque por leuallas beua con ellas y beua quantas veses quisiere, ca te digo cierto que esta agua le rrefresca y ensancha el buche y le 
quita aquellos vapores y le ayuda á gastar y á correr más presto las tripas. E aún es esto muy bueno, que la pluma que entonces le ayas de dar sea mojada en el agua tibia. A los otros falcones que comen de huelga ó á sus oras ciertas bien es no dalles más á beuer de quanto le pruevas que el agua que entonces él beuerá si la quisiere ó ouiere gana.

Capítulo xxxir.-Del que rregita la vianda que le dan.

Este rregitar de falcones es una mala dolencia. Auemos dicho en la glosa pasada que cumple que el caçador vea si viene de frio ó de filomeras y lombrises, porque así le aplique las melesinas, ó de cordero. Algunos falcones mios he mandado yo curar rremojando cuajo de cabrito ó de cordero en agua de llantel y mojarle en aquello vnas picadas de pierna de pollo ó de pierna de palomino ó en coraçon de paloma ó de gallina, y si esto regita y no sufre ningunas picaduras de carne, mándole dar manteca fresca lauada en nueue aguas, buelta con rna yema de hueuo asado, tanto de manteca como dos vezes la yema, $\mathrm{y}$ todo mojado $\mathrm{y}$ mesclado $\mathrm{y}$ metido en pelotillas de rrato en rrato, como se conociere auer tollido la cantidad que se le dió. I si esto regitare, darle la manteca amasada con dos partes de poluo de yerua buena y una parte de poluo de almástiga, y así aprouechándole qualquier destas cosas dichas, yrle ayudando con picaduras de sangre ó coraçon de paloma ó pierna de pollo chiquito, de manera que torne á cobrar su sustancia y desistion. I creo que si alguna cosa le ha de aprouechar, esto ha de ser, porque por experimento lo tengo visto. Pero si el rregitar acaesciere de rremanescer con papo, pruéuale el agua y dale el sol que vieres que ha menester y ponle en vna cámara que non sea vmida, y á la noche darle as de vna pierna de polla ó de rn coraçon de carnero desollado y desvenado, porque el buche pueda gastarlo y tornar á su natural. 


\section{$19^{5}$}

Capítulo xxxvi. - De cómo se deuen de curar quando se les salen las tripas.

Lo que en esto yo mando faser á mis alcones es la costura que sea como aquí dice, y sobre ella que pongan vn paño de trementina caliente y le vnten con el aseite de lonbrises muchas veses al dia. Pero deues mirar si en alguna parte tiene la tripa rrompida, y si tal es, toma la llaga en los dedos muy junto, como quien lo quiere coser, y toma hormigas que sean grandes y apriétalas por medio demanera que abran la boca y muerdan en aquellos lávrios que tienes así juntos. E desque la hormiga aya apretado, córtala por medio de guisa que la cabeça quede allí, y así pornas destas cabeças quantas vieres que cumple y ponlas bien espeças y mételas dentro y cose con aguja y filo de seda la llaga de fuera, como aquí dise. Asimismo deues mirar que si el falcon há rrato que tiene las tripas fuera que se ynchan mucho por el ayre que rrescibe, y despues non puede tornar por donde salieron, que non caben. E para esto conuiene que fagas así: toma vn puño de anis y otro de cominos y otro de flor de mançanilla y cuésello en vino tinto y tiuio en buena manera, caldéagelas muchas vezes y enxúgalas con vn paño, y luego tornarán á entrar. I en el otro caso que dise de quando las tripas salen sin ser rrompido el cuero de fuera, yo la hé por grave cura, y lo que yo mando faser es esto: que le trasquilen aquel lugar muy mansamente y le pongan allí en un parche vn poco de enplasto que se dize contra rotura. I si esto non bastare, corta el cuero muy sotilmente, que non penetre adentro, y metidas bien las tripas cósele la carne y cuero todo junto, y porque mejor encarne toma vna lanceta $y$ desuéllales los labros de aquella rrotura, de manera que faga sangre no más, y despues pasarle as

la cura como es dicho: esta es cura buena y prouada.

FIN. 



\section{TABLA DE LAS GLOSAS}

DEL

\section{DUQUE DE ALBURQUERQUE.}

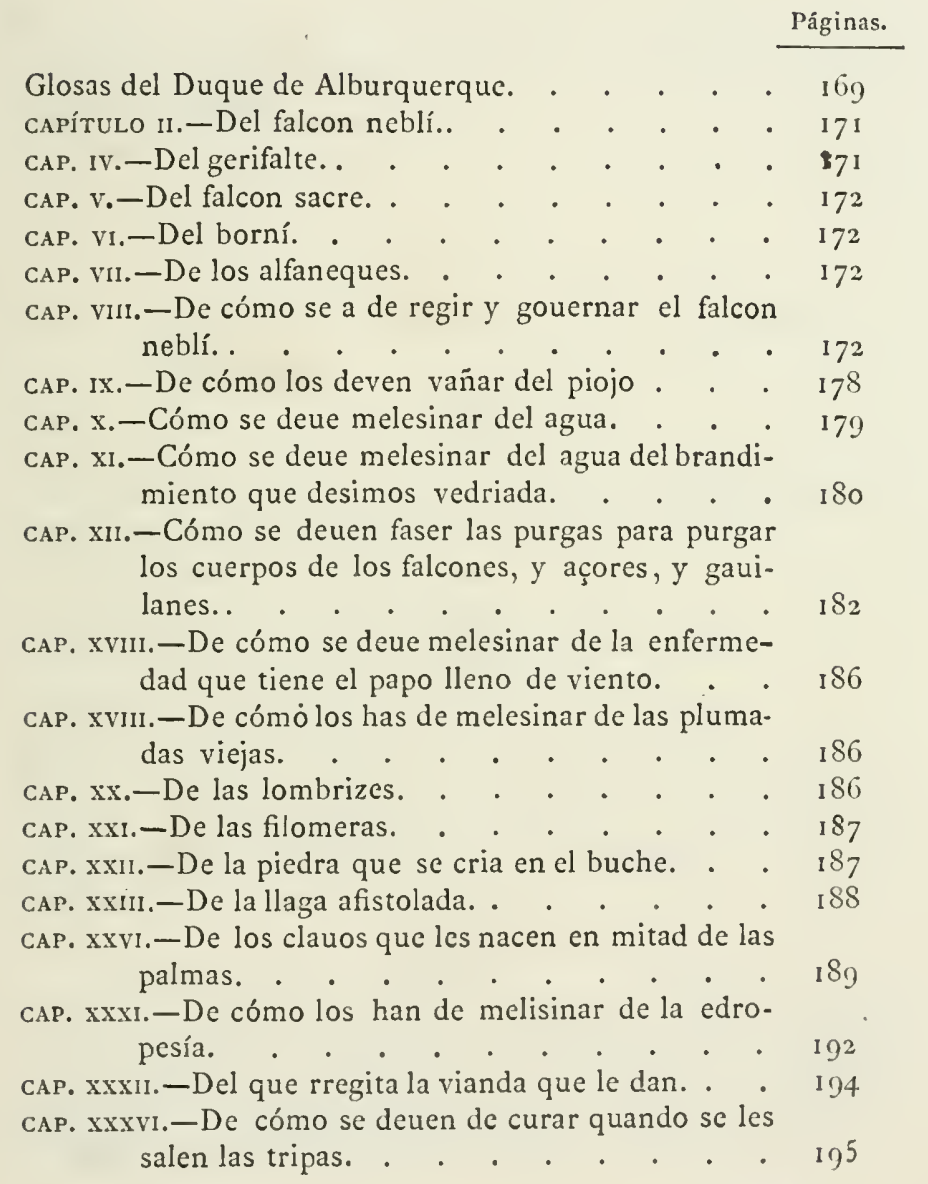





\section{INDICE ALFABÉTICO}

DE NOMBRES PROPIOS Y GEOgRÁficos CITADOS EN EL. LIBRO DE LAS AVES det, CANGILler PERo l.opez dE ayala, y GLOSAS del dUQUe DE ALBURQUERQUE.

A.

Aifonso (Lucas), gran cazador de Esclavonia; criado del viccCanciller en Roma-180, I89.

Alfonso Virey de Nápoles-18o.

Alhabíba-isla de, en Africa- 35 .

Arrle-Arlés, ciudad de la Provenza-32.

Asuéga-Suecia-16, 142 .

Aybor-el valle por donde corre el lbor, rio que entra en el Tajo á una legua de Valdeuncar. El capítuloxiv del Libro de cetrevía de D. Fadrique de Zúniga Sotomayor trata de los "açores de Ibor, que es cabe Guadalupe do son los montes que llaman de Toledon.-147.

B.

Bergoñia.-Está por Borgoña, y su duque no pudo ser otro al tiempo que escribia el Canciller, sino Felipe el Atrevido (Philippe le Hardi), hijo del rey de Francia Juan I, llamado el Póstumo. Nació en 1342 , murió en $1404-12,148$. 
Bramante-es Brabante, antiguo ducado del imperio germánı co en el círculo ó circunscripcion de Borgońa $\rightarrow 12$.

$$
\text { C. }
$$

Calahorra-halcon neblí del rey D. Pedro-68.

Crao (el) de Arrle.-Es La Crau, llanura pedregosa junto á Arlés en la Provenza-3z.

D.

Die z de Mendoça (Ruy). Es Ruy Diaz de Mendoza, vigésimocuarto almirante de Castilla en tiempo de Enrique III. Fué hijo y sucesor en el cargo de Juan Hurtado de Mendoza, seńor de Mendivil-12, 172 .

$$
\text { E. }
$$

Enriquez (D. Enrique), hijo de D. Pedro Enriquez y nieto de D. Fadrique el maestre de Santiago, hijo natural de Alonso $\mathrm{Xl}-12$.

$$
\text { F. }
$$

Fernande Burriello (Juan), halconero del rey D. Pedro-12, 56,68 .

Flandes (conde de). Eralo por este tiempo Luis de Male por herencia de Margarita, hija de Juana II-12.

$$
\text { G. }
$$

García, el Romo (Ferrand), halconero del rey D. Pedro-68. Come de Alborno $\tilde{z}$, comendador de Montalvan-p. 12.

Goñale đe diliescas (Ruy), comendador de Santiago, halconerodel rey D. Pedro-22, 114 .

Gužman (D. Johan Alfonso de), el primer conde de Niebla-p. 12.

I.

Illa (Vizconde de), gran cazador-93, 14.8, 
Jordan Durres (Pedro), mayordomo mayor del rey de Aragon; es Pedro Jordan de Urríes.

\section{L.}

Lenguadoc-El Languedoc, provincia de Francia-32.

Lipũ̃coa-Guipúzcoa-144.

Loarte (Diego), cazador mayor del duque de Alburquerque -189 .

Lorenço (Ramir), comendador de Calatrava, gran halconero-52, 56 .

M.

Manrreça-Manresa, cazador mayor del rey D. Enrique IV -189 .

Manuel (D. Juan), hijo del infante D. Manuel, y señor de Villena-12.

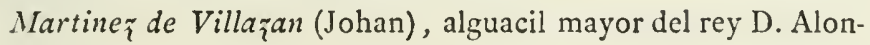
so $\mathrm{XI}-\mathrm{I} 2$.

Mena (D. Gonzalo de), obispo de Burgos-1, 12.

Mendez (Alfonso), halconero del rey D. Pedro-22.

Meniño (Pero), halconero mayor del rey D. Fernando de Portugal-12. Parece ser el mismo citado por S. Fagund.

Milana-El ducado de Milan-164.

\section{N.}

Nuruega-Noruega-18.

O.

Orejon, capitan de una galera del rey D. Pedro-154.

$\mathrm{P}$.

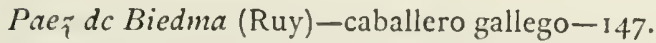

Pristalejo-halcon torcuelo de Garci Laso de la Vega-32. 
Poca-ropa-nombre de un halcon nebli del duque de Alburquerque -154 .

Pruça-Prusia-I8.

R.

Ramirę̆ de Guそ̄man (D. Diego)-obispo de Leon-32.

S.

Sant Exidro-San Isidro ó Isidoro.

T.

Tangravilla (conde de)-es Juan, vizconde de Melun, y conde de Tancarille, en Normandia, que murió en $1382-12$.

$\mathrm{V}$.

Vega (Garci Alfonso de la) caballero de Toledo-12.

Y.

Yxar (don Luide), hijo del conde de Aliaga en Aragon-1 75 . 


\section{GLOSARIO}

\section{DE VOGES ANTIGUADAS.}

Aberramia.-Averamia, especie de ánade. César Oudin en su Diccionario trilingiie escribe Avertamia. -51 .

Abocasta.-Avucasta, por otro nombre avetarda ó abotarda. - I 8 .

Aceuar cecotrí.-El acibar, ó linaloe socotrino, asi llamado por criarse en la isla de Socotra. -70 .

Aceuar pátigo.-El acibar llamado hepático por parecerse al hígado en el color. -81 .

ACEtrero.-El físico ó cirujano de aves, halconero, el que se ejercita en la cetreria ó accipitraria.-56.

Acerner.-Cerner, separar con cedazo.-105.

ACUC1A.-Diligencia, solicitud. -49 .

Afeytarse.-Componerse, esmerarse.-48.

Afogadizo, adj.-El que tiene propension á ahogarse.-117.

Agua vedriada.-Humor congelado, materia, moquillo que padecen los halcones y otras aves de rapiña. -7 .

Aguada, adj.-El ánade que de miedo del halcon se mete y zabulle dentro del agua. -49 .

Aguatocha.--Jeringa que usaban antiguamente los plateros para polvorear las soldaduras. -179 . 
Alambor.-V. Atanbór.

Alcahaz, jaula.-Es voz arábiga de cafaz.-147.

Alcambor.-V. Atanbór.

Alcandara. - Voz arábiga con que se designaba antiguamente la percha ó varal en que se ponian los halcones. - I 5 .

Alcatraz.-Especie de ave acuática.-10.

Alcotan.-Especie de halcon mayor que el gavilan y menor que el esmerejon. Es voz arábiga de al-cottám.-8.

Alcaruan.-Es voz arábiga al-carrán.-23.

Alçadera. - Cierta ave acuática de la especie de los ánades. $-48-5 \mathrm{r}$.

Alesna.-Lezna, instrumento que usan los zapateros. - 67 .

AlFaneque.-Especie de halcon blanquecino con pintas pardas que se cria principalmente en Tunez. Viene del árabe al-foneye. -7 .

Alfayate.-Sastre; es voz de orígen arábigo, de jayyát, usada aún en Portugal.-94.

Alholuas. - La planta llamada en latin foenum groecum; es voz árabe al-holba.-185.

Aliviamiento.-Alivio, descanso, desahogo.-2.

Almástica. - La resina llamada por otro nombre Almáciga.-123.

Almodacil.-V. Armodátil.

Alosna.-Encenso, amargo, ajenjos.-I 19.-I 20.

Aloya.-Especie de calandria sin cresta, en latin alauda.-149.

Alquitira.-La goma llamada por otro nombre goma dragante (tragacanthum); es voz arábiga.

Altemisa. - La planta llamada artemisia.-i 87.

Anade genta.-Anade gentil.-5 I.

Apopana.-El opoponac, especie de goma resinosa.-I9I.

ARÁvigo, adj.-El halcon zahareño ó salvaje. -18.

Armodátil.-Hermo dactylus, raíz tuberosa, suavementc purgante. Hállase tambien cscrito Almodácil.-185.

ArmuYaca. - La goma amoniaco, llamada en latin bárbaro armoniacum. $-19 \mathrm{I}$.

Arraigan.-Arrayan.-Igl.

ARREDRAR.-Volver hácia atrás. - I 3 .

Arrexaca.-Instrumento de hierro con tres puntas; es árabe, de Arraxaca. -50 .

Arrincado, adj.-Arrancado.-101. 
Arrostolagra.-Aristoloquia, yerba medicinal.-18g.

Arsolla.-Arzolla, la centaurea paniculata 6 cardo lecherO.-I92.

Asañar. - Ensañar, encolerizar.-20.

Asombrado, adj.-Atemorizado, espantado.-7.

Atahorma.-Ave de rapiña, llamada por los portugueses altaforma.-10.

Atanbór. - Tamborcete que se usaba antiguamente en la caza de cercetas y otras aves acuáticas. Hállase tambien escrito Alanbor, Alcambor y Latambor.-147.-164.

Atibiar.--Entibiar.-64.

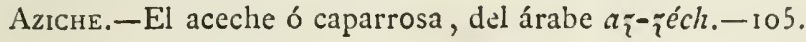

B.

BAUADA.-Baba, espuma.-69.

Baharí, Bahary.-Especie de halcon llamado tambien gentily tagarote, y que por criarse en Cerdeña, Mallorca y otras islas era designado con el nombre de Baharí ó el Ultramarino; en portugués bafarí. $-2 \mathrm{I}$.

BALDRÉs.-Valdés, piel curtida y suave que sirve para guantes.-102.

Bermesiço, adj.-Lo que tira á bermejo.-191.

Bitor.-Especie de alcaravan; en francés butor. -57 .

Blanchante.-Especie de halcon nebli, asíllamado en Francia. Blanchard?-19.

Bolar menique. - Está por bolarmenico, ó bolo arméniCO.-102.

Bolería.-Vuelo, voladura.-20.

Boltura.-Bulto, tamaño, vuelta. -35 .

BoRNY.-El halcon llamado por otro nombre lanero. $-3 \mathrm{I}$.

Brandimiento.-Blandimiento, movimiento. - i 80 .

Bretónica.-Betónica, yerba medicinal.-193.

Brozno, A, adj.-Bronco, tosco, áspero.-I9.

BuArRo açoreño.-Buharro, ave de rapiña parecida al azor.

-174 .

Bubilla.-Abubilla; en latin upupa.-15 I.

BuÉtago.-Bofe.-I I 9 .

BUetre.-Buitre; de vultur. 


\section{6}

Burniniego.-El borní niego ó sacado del nido.- 19 r. BuYEs. - Bueyes. -132 .

C.

Canin,-Lo mismo que canino.-I7I.

Canino, A, adj.-El que come á la manera del can ó perro.- I01.

Caniuete.-Lo mismo que Gañiuete.

Cañada. - El tuétano de los huesos. - 57.

Capil veneris.-Culantrillo de pozo; en latin capillus veneris. -95 .

Capjrotero, adj.-El halcon que se acostumbra fácilmente al capirote. -74 .

Capusada. - La cugujada. - 36.

Carniças. - La carne muerta.-9.

Carrellada. - La carrillada ó carrillar q. v.-108.

Carrillar. - Las quijadas del ave. -134 .

Casca.-Cáscara.-105.

Caxa. - Lo mismo qne vara, ó varal para llevar halcones.-i 55.

Cecotrí.-V. Aceuar.

Ceraça.-Ungüento compuesto de cera, aceyte y otros ingredientes, por otro nombre cerato. -45 .

Cerrenicalo.-El cernícalo, ave de rapiña.-155.

Cieço.-Sieso. - 188 .

Ciguńela. - Dim. de cigüeña.-147.

Ciridueña. - La yerba llamada por otro nombre celidonia ó celidueńa.-I 84 .

Clavo.-Tumor ó hinchazon en los piés.-26.-103.-104.

Coca.-Especie de embarcacion muy usada en la edad media. Tambien se dijo conca del latin concha. - I43.

СоноцLo.-Cogollo, lo interior de ciertas hortalizas y plantas, latin cucullus.-I91.

Colocunda. - La yerba llamada coloquíntida. -183 .

Conca, - V. Coca.-143.

Cornesiso.-El depósito que se forma en el buche del ave. -85 .

Conbeso. - Mata cuya hoja es parecida á ia del trébol.-90.-167 .

ConTrés.-Del francés contrée, territorio, país.-i 6 .

Copla.-Par, conjunto de dos cosas iguales; copula. -33 .

Coradillas. - Las asaduras de la gallina.- 193 . 
Cornejal. - El ángulo, esquina ó punta de la boca. -134

Coronado, adj.-Especie de halcon.-ig.

CRUA. - Lo mismo que grua ó grulla.-I 24.

Cuchillos. - Las plumas largas en el ala del halcon. - 137 .

Cuneso.- La mata llamada en latin cytisus. -187 .

Cuega. - Está por cuezca, ó cuezga del verbo cocer.-191.

Cueros de abadía. - Piel de becerro adobada para los capirotes de los halcones. -163 .

Cuxa.-Muslo del ave, fr. cuisse. -20 .

\section{Ç.}

Caboque.-Pájaro pequeño. $-15 \mathrm{r}$.

ÇAHARA. - Bravura, esquivez. -40.

Çaharex̃o, A., adj. -El falcon salvaje, ó bravo; en portugués çafaro. -18 .

ÇANCo.-La zanca ó pierna del ave, desde la garra hasta la juntura del muslo. -110.

\section{D.}

DapNarse. -Dañarse, hacerse daño. -53.

Dardavasin. - Dardabasí, especie de milano.-174.

Departir.-Altercar, discutir, dando diferentes pareceres. - 3

Derramadamente.-Esparcidamente, por do quiera. -46 .

Desalarse.-Arrojarse el halcon sobre la presa con precipitacion y con ánsia, como si no tuviera alas.

DESAYNar. - Rebajar la grosura ó sain al halcon.-141.

Desecar. - Enflaquecer, secarse, consumirse. 72 .

Desenpulgar. - Soltar las pihuelas ó correas del halcon.-ro2.

Desí, adv.-Compuesto de des, y $h i$ ó $i$, desde allí, despues. -110 .

Desistion.-Digestion.-194.

Deslanado, adj.-Aplícase al plumaje de los halcones, cuando ha perdido la pelusa.-17.

Destilla. - Las destiladuras ó gotas de sangre que manan de una herida. -122 .

Diagrid.-Preparacion de la escamonéa.-185.

Diaquillon.-Emplasto ó ungüento desecativo.-105.

Donzella. - Especie de halcon nebli, así llamado.-19.

Dudalon.-Cierta ave de rapiña.-10, 144 . 


\section{8}

E.

EnçEnco.-La yerba llamada por otro nombre encienso ó ajenjo. -98 .

Ençenso amargo.-V. Alosna.

Entecado, adj._Enteco, débil.-38.

Entrecelo. - Especie de halcòn de tamaño medio entre tagarote y alfaneque. -35 .

ENTRECELY, adj.-El halcon mixto de tagarote y alfaneque.-36.

Escalfado, adj._-Calentado, hecho caliente, excalefactus.-119.

EsCARA. - La telilla ó costra formada del humor de una llaga, schara. -189 .

Esclamonia. - La escamonea, sustancia medicinal purgante extraida de la yerba del mismo nombre. -185 .

Esclavo.-El halcon procedente de Esclavonia.

Escudete.-Las asperezas, á manera de escamas, en la pierna del azor; cierta parte de la pierna de la gallina.-I ig.

EsMerejon.-Ave de rapiña, llamada por otro nombre "esparavan $n .-9$.

Esparuel.-Especie de gavilan, del fr. espervier.-I 48 .

Espeluzarse.-Espeluznarse, erizarse los cabellos de miedo ó espanto.-I7.

Espic.-El espique ó espicanardo.-64.

Espirencia.-Experiencia.-3.

Esquivada, adj.-La garza ú otra ave que huye delante del halcon y le evita por miedo que de él tiene. -57 .

\section{F.}

Fasaleja.-Fazaleja, paño de cara, toalla, del lat. facies. -188 . FaUarrás. - Habarráz ó yerba piojera; es voz árabe que significa "yerba de la cabeza".-6o.

FAYA.-Haya. -154 .

FEBLE, adj.-Delicado, débil, del fr. faible.-38.

Filandra.-Especie de lombriz que se cria en el intestino de los halcones. -92 .

Filomeras. - Lo mismo que Filandra, q. r.

Fincar.-Quedar.-II.

Fistolarse.-Convertirse la llaga en fístola. -97 . 
Floxel.-El pelillo del ave, cuando no llega aún á ser pluma. $-39,179$.

$\rightarrow$ Fluche. - Laguna del flamenco fluys. -44 .

FoJa PENCA.-La hoja de ciertas hortalizas como el cardo, la col, etc. $-\mathrm{I} 62$.

Fornecino, adj.-El halcon bastardo.- 15 .

Fuelgo.-Huelgo, aliento, resuello. -45 .

\section{G.}

Galua.-Así escrito en el códice $A$ puede leerse Galia ó Gal-' $v a$, y si el escribiente omitió una tilde sobre la a Galvan, en cuyo caso podrá ser el gálvano ó gálbano, cierta resina gomosa y me. dicinal.- I 9 I.

Gax́ıuete.-Lo mismo que Canivete, q. v.-I 4,45 .

Gargantada.-Buchada, bocanada, la porcion de líquido que cabe en la garganta. -8 I.

Gargantero, adj.-Gloton.-77.

Garçota.-Garza real.-i8.

Garico.-El agárico ú hongo que se cria en el tronco de los alerces. $-\mathrm{I} 8 \mathrm{I}$.

Garisco.-Agarico?-186.

Gánia.-La vara ó palo largo para llevar halcones.- I 58.

Gengifre.-Jengibre, raíz medicinal que se cria en la isla de Zangibar.- 185 .

Gentil, adj.-Fijo dalgo, y tambien el halcon llamado neblí.-I 5.

Gento, adj.-Ánade genta, ánade gentil, graciosa.-5.

Gineta-Especie de ánade, 51 .

Girifalte.-Gerifalte, especie de halcon de color pardo oscuro, con listas cenicientas y patas rojas; Gyrfalco en fr. gerfalt y gerfaut. $\mathrm{I} 4$.

GOLPADA, adj.-El ave que ha recibido un golpe.-49.

Golpar.-Caer de golpe sobre una cosa; dícese del halcon cuando cae sobre la presa. -47 .

GorGA.-Gorja, garganta; el alimento que cabe en la gorja de un halcon, en fr. gorgée. -7 .

Grisa.-Especie de ardilla, así llamada por el color de su piel. -25 .

GruA.-Grulla.- - I0.

GRUERO.-El halcon que ataca ó se hace á gruas ó grullas.-20. 


\section{$\mathrm{H}$.}

Huélfago.-Enfermedad de los halcones que les hace respirar con dificultad. -56 .

\section{L.}

LABRo. - Labio. - 195.

LANERo, adj.-Halcon cuyo plumaje parece lana: falco lanarius. -14 .

LARDon.-Lonja de tocino, tira de gordura. -70 .

Litambor. - V. Atanbór.

LAVRIO. - Lo mismo que LABro. - 195.

LAYDo, adj.-Feo del fr. laid. -6 .

Lechuela.-Lechuza, 5 I.

Lensesıco.-Diminutivo de lienzo, paño.- $\mathbf{I} 8 \mathbf{2}$.

Letrado.-Especie de gerifalte así llamado por el plumaje. -28 .

LiJARSE, LiJiARSE.-Lisiarse, herirse, hacerse daño.-48.

Linjavera. - La bolsa de lienzo que el falconero debe traer al costado. $-41,164$.

Livor.-Quebrantadura ó rotura de hueso, herida.

Lixo.-Suciedad, inmundicia.- -125.

Lonja.-La correa larga que se ata á las pihuelas del hal. con. -42 , 114 .

LuA.-Guante.-42.

\section{M.}

Maçlo.-Maslo, la raíz de las uñas.

Marrotarse.-Moverse con violencia, sacudirse.-158.

Mastrujar. - Cargar sobre una cosa comprimiéndola.-I89.

Mechuela.-Diminutivo de mecha.

Melisina.-Medicina, medicamento.-I9I.

Mesar.-Caerse la pluma ó pelo.-63.

Milaña. - Cascabeles de los que se hacian en Milan. - 53.

Mirasolis.-La simiente del cáñamo silvestre ó montesino.-95.

Mochina, adj.-La carne que es de difícil digestion y pesada para el estómago. -50 .

Momia.-Cuerpo embalsamado de los antiguos egipcios que reducido á polvo se usaba como medicamento.- I 10 . 
Monterí, adj.-Montés, nombre dado en Aragon al halcon baharí.-23.

Muermo.-El humor viscoso que el halcon arroja por las narices. -65 .

Múmia.-Lo mismo que momia, q. v.

N.

NeBí.-El halcon gentil, y por otro nombre neblí.- 15.

Neblí.-Especie de halcon llamado por otro nombre gentil y pelegrin.-15.-Aunque el autor deriva esta voz de Nebí, parece más natural etimología la de Neblí que señala Johan de Sant Fagund (cap. I.) cuando dice: "Estos falcones llaman en Castilla neblis, porque los primeros que en España ovo fuéron tomados en Niebla. En Aragon los llaman pelegrines, porque pasan la mar cada año. Uvolos un cavallero que decian Florendos, el Gordo, que era señor de aquella tierra, y era gran cazador de aves, y esto fué en tiempo del rey Bamba."

NIEGo, adj.- El azor ó halcon cogido en el nido nidiego del lat. nidicus; los portugueses le llaman ninhego. V. Burniniego.

Niso.-Esforzado, valiente del lat. nixus. El portugués Diego Fernandez Ferreira, en su Arte de caça da Altanería (Lisboa, I $\left.6 \mathrm{r} 6,4 .^{\circ}\right)$, fólio 6 , dice á propósito de este vocablo: "Estes gaviaés se chamáo en latin Nisos, que quer dizer esforçados. -1 .

0.

Obero.-La overa del ave.-I I8, I7 7 .

Orinescer.-Enmohecerse, cubrirse de orin.-162.

OrRura.-Horrura, vascosidad, suciedad, malos humores en el cuerpo. -50

$$
\text { P. }
$$

PARARSE.-Prepararse, prevenirse.

Pátıgo, adj.-Hepático, lo perteneciente al hígado. V. Aceuar.

Pelegrin.-Peregrino; nombre que en Aragon y Cataluña dahan al halcon nebli. -15 .

Pelezilla.-Diminutivo de piel.

Pelligero.-Pellejero, el que adereza pellejos para vino, accite, etc.

Pex̃ola.-Pluma, pennula de penna.-I7. 
Pepttorta, adj.-La gallina que está con pepita.-5o.

Pescoçudo, adj.-El que tiene mucho pescuezo.

Pıcaçero, adj.-El halcon alfaneque que se ataca á las picazas ó urracas.

PlCADA.-La carne que el cazador da de comer á su halcon para tenerle "contento.--195.

PlHuela.-Pihuela, la correa con que se aseguran los piés de los halcones; pedicuela, del latin pedica.-108.

Pimpinella. - La yerba llamada por otro nombre bursa pastoris ó bolsa de pastor. -115 .

Pinpanillat.-Pimpinella?-ISS.

Plunid.-Lo mismo que Plumada.-7.

Plumada.-Curalle ó pelotilla de plumas blandas, algodon ó hilas que mezclada con sustancias medicinales se daba á los halcones para purgarlos. El conjunto de plumas viejas y"no digeridas que se les forma en el buche.- I92.

Premir.-Apretar, oprimir.-95.

Prestor.-Prision, todo género de aves ó animales que son presa del halcon.-3.

Preto, adj.-Negro, oscuro, prieto.

Pristo.-Prisco?-178.-187.

Provincial, adj.-El oriundo de Provenza. Nombre que se daba en Castilla al halcon lanero traido de aquella region. -148 .

Puño.-Puñado.- I 95.

Psalmista. - Psalterio.-4.

R.

RaPeLA.-Falcon que se coge en Febrero; del francés rappel-17.

Rayllo.-Especie de ánade.-5 I .

Recreaniento.-Recreacion, recreo.-1.

Regitar, Regrtar. - Vomitar, vaciar, arrojar; del fr. rejetter. -122 .

RemaneçER.-Quedar.-7.

Remondar.-Dejar una cosa enteramente limpia, mondarla segunda vez. -56 .

REPreso, adj.-Reprimido, contenido. -177 .

Resuelgo.-Resuello, aliento, respiracion.-26.

Roçrs.-La tierra rozada ó limpia de matas y yerbas, preparada para la siembra.- -18 .

RoEdero.-El hueso que se da á roer á los halcones. -26 . 


\section{I 3}

Roquez. - Especie de halcon de plumaje oscuro y casi negro.-20-23-25-33.

RuY Pontico.-Ruypóntico vulgar; centaurea major. $-18_{4}$.

S.

SARDo, adj.-El halcon que viene de Cerdeña.-143.

Sarquecola,_Sarcacola, especie de goma.-iso.

SAYN.-Sain, gordura de cualquier animal.-140.

Señolar. - Hacer uso del señuelo en la caza con halcon. -42.

Sex́olero, adj.-El halcon que responde y acude bien al señuelo. -18 .

Señuelo.-Señuelo, el cojinillo de cuero con que se hacia scñas ' al halcon, signolum.- -42 .

SERaP1.-Serapea, especie de goma llamada por otro nombre sagapeno y serapino.-191.

Sobejanía.-Exceso, demasía.-81.

Sobrado, adj.-Lo que está de sobra ó de muda. -54 .

Sostra.-Costra?-io5.

Suadorio. -Sudorífico, medicamento para hacer sudar á un enfermo. -66 .

Suelda.-Soldadura, ungüento que se les daba á los halcones por la boca para curarles ciertas heridas. - I 10.

Suelda MENor. - La simiente de cierta yerba menuda que sirve para sueldas de halcones. -110 .

Suelda Raca. - En Johan de Sant Fagund, suelda de rata, cspecie de purga para los halcones. - i ir.

T.

TAGarote.-Especie de halcon más pequeño que el neblí, aunque del mismo plumaje.-23.

TAGre. - La muda de cierto halcon neblí que se cria en Astúrias. Tagle? -32 .

Talantoso, adj.-El que tiene talante ó disposicion para hacer alguna cosa. -90 .

Taluo.-Ave parecida al cuerro.-51.

TÁrtago.-Purga compuesta principalmente de la yerba así llamada, -70 .

Testuço.-Testud, la union de la cabeza y pescuezo. -67 .

Tijeras. - Las primeras plumas del ala del halcon.- 45 .

TiRaR.-Sacar, quitar, arrancar. -100 . 
Tol.Leduras. - Excremento del ave,-45.-118.

Torcaza.-Paloma torcaz ó silvestre; columba torquata. $-1+4$.

Torondo.-Tolondro, bulto, chichon.- 108 .

Torquesas, Turquesas. - Tijeras turquesas, las tenazas ó alicates. $-101 .-1$ อั 8 .

Torulque.-V. Turbique.

Tragonía.-Glotonería.-9.

Trayna.-Cualquier pieza de caza con que se atrae al halcon para acostumbrarle al vuelo de altanería; del francés trainer, que es avezar ó acostumbrar. Treinar en portugués significa enseñar á un halcon á que ataque raleas que de otro modo no atacaria.-26.-144.

Trópico, Trópigo.-Hidropesía. -73-116.

Trullo.-Ave acuática parecida al ganso, aunque más pequena: latin trulio. -48 .

Tullir. - Lo mismo que Toller y Tolleduras q. v. -7o.

Tunizo, adj.--Tunecí, tunecino, el falcon procedente de Tunez en Africa. -35 .

Turbique. - El turbite, planta resinosa y purgante. -185 .

$$
\text { V. }
$$

VAquilla.-Dim. de vaca, por baca ó frutilla silvestre, en latin bacca. -191 .

\section{$\mathrm{X}$.}

XARA.-Jara.-191.

VAra. - Percha ó varal en que se llevan los halcones.-128.

Vedriarse. - Vidriarse el agua, es congelarse y ponerse á manera de vidrio. -61 .

$$
\text { Y. }
$$

YAGA.-Está por yazga del verbo yacer.-119.

YEGUADo, adj.-Igualado, a'quatus.-122.

Yuntura.-Coyuntura, juntura que forman dos huesos entrando el uno en el otro. -4 I.

\section{Z.}

- Zorzaleño, adj.-El halcon pintado como inr $\tilde{i}^{a l .-19}$ 


\section{ERRATAS.}

\begin{tabular}{|c|c|c|c|}
\hline Págs. & Lin. & Dice. & I.éase. \\
\hline 10 & 33 & Omiten........ & omite. \\
\hline 36 & 28 & todas que.. . . . . . & todas las veces que. \\
\hline $4^{6}$ & 28 & derrauiadamente.. . . & derramadamente. \\
\hline 56 & 7 & derrauiadamente.. . . & derramadamente. \\
\hline $8_{1}$ & 17 & saragotona..... & zaragatona. \\
\hline $9^{5}$ & 8 & todo......... & toda. \\
\hline 110 & 2 & déveles. . . . . . . & deveslos. \\
\hline II I & 9 & saquite. ...... & saquete. \\
\hline 127 & 5 & cartigo. . . . . . . & castigo. \\
\hline 144 & 32 & ca et mala.. ...... & ca es mala. \\
\hline 150 & 29 & fiendole........ & fiéndele. \\
\hline 161 & 8 & gañinete. . . . . . & gańiuete. \\
\hline 164 & 20 & caxeras........ & caxetas. \\
\hline 177 & 17 & de saynar...... & de desaynar. \\
\hline 178 & 33 & so fin. . . . . . . . & sofrir. \\
\hline 179 & 36 & provecharle á lavarle. & aprovecharle-a lavarle. \\
\hline I 80 & I 9 & la sol. . . . . . . . . & al sol. \\
\hline$"$ & $3 i$ & vidar. . . . . . & vi dar. \\
\hline${ }_{1} S_{2}$ & I & tornique. . . . . . & toruique. \\
\hline$"$ & 35 & prúenle.. .... & $\begin{array}{l}\text { pruebenle ó denle á pro- } \\
\text { bar. }\end{array}$ \\
\hline 183 & 33 & ser el caçador. . . . . & el caçador. \\
\hline 184 & 12 & si non está.. . . . . & sinon esta. \\
\hline 186 & 29 & de lançaron. ..... & del ançaron. \\
\hline 191 & 3 & liebras........ & liebres. \\
\hline$"$ & 9 & acipues....... & aciprés. \\
\hline$"$ & 13 & 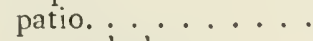 & pano. \\
\hline$"$ & 29 & y mezclarlas. . . . . & y mezclarlas-as. \\
\hline$"$ & 33 & vermégicas.. . . . & vermegícas. \\
\hline$"$ & 34 & y majalas ....... & y majárias. \\
\hline
\end{tabular}





\title{
$\operatorname{SOCIED} \Lambda \mathrm{D}$
}

\author{
$D E$

\section{BIBLIOFILOS ESPAÑOLES.}

1. Excmo, Sr. D. Juan Eugenio Hartzenbusch.

2. D. Pascual de Gayangos.

3. D. Cayetano Rosell.

4. Illmo. Sr. D. Braulio Anton Ramirez.

5. D. José Godoy Alcántara.

6. D. José Almirante.

7. D. Mariano Carderera.

8. D. José Fernandez Gimenez.

9. D. Mariano Vergara.

ı. D. José María Escudero de la Peña.

11. D. Francisco Asenjo Barbieri.

I 2. D. Santos de Isasa.

I3. D. Antonio Peñaranda.

I4. D. José García y García.

15. D. Vicente Vignau.

I6. Illmo. Sr. D. Miguel Colmeiro.

17. Lllmo. Sr. D. Manuel Colmeiro.

I8. D. Valentin Carderera.

19. D. Juan Facundo Riaño.

20. D. Jacinto Sarrasí.

21. D. José de Castro y Serrano.

22. D. Ramon Llorente y Lázaro.

23. D. Toribio del Campillo.

24. D. Gregorio Cruzada Villaamil. 


\section{18}

25. Excmo. Sr. D. Antonio Cánovas del Castillo.

26. D. Cándido Breton Orozco.

27. D. José María Octavio de Toledo.

28. D. Manuel Oliver y Hurtado.

29. D. Manuel Rivadeneyra.

3o. D. Manuel Rico y Sinobas.

31. D. Cárlos Castrobeza.

32. D. Genaro Alenda Mira de Percebal.

33. D. Anacleto Buelta.

34. D. Máximo de la Cantolla.

35. D. Fernando de Castro.

36. D. Jacobo Zobel.

37. D. Manuel Lasala.

38. D. Eugenio Maffei.

39. D. Feliciano Ramirez de Arellano.

40. D. Francisco Moya.

4 I. La Biblioteca Nacional.

42. D. Joaquin de Azpiazú y Cuenca.

43. D. Vicente Barrantes.

44. D. Julian Sanchez Ruano.

45. D. Raimundo Gonzalez Andrés.

46. D. Joaquin Cevallos Escalera.

47. D. Sebastian de Soto.

48. Excmo. Sr. Marqués de la Mesa de Asta.

49. D. Rafael Contreras.

5o. Excmo. Sr. D. José Gutierrez de la Vega.

51. Excmo. Sr. Marqués de la Vega de Armijo.

52. D. Francisco Escudero y Perosso.

53. D. Manuel Tovar Opacio.

54. D. Pedro Antonio Albeniz.

55. Excmo. Sr. D. Trinidad Sicilia.

56. Excmo. Sr. D. Manuel Silvela.

57. D. Fermin Hernandez Iglesias.

58. Sr. Marqués de Santa Marta.

59. D. José Perez de Guzman.

6o. D. Ricardo Heredia.

6I. D. Mariano de Zabálburu. 
62. Excmo. Sr. Marqués de Almaguer.

63. Excmo. Sr. D. José Posada Herrera.

64. D. Eduardo de Mariátegui.

65. La Biblioteca del Ministerio de Gracia y Justicia.

66. D. Emilio Ruiz de Salazar.

67. Excmo. Sr. D. Antonio Hurtado.

68. D. Rafael Blanco y Alcalde.

69. D. Isidro Autran.

70. D. Francisco Cutanda.

71. D. Luis Vidart.

72. Excmo. Sr. Conde de Villanueva de Perales.

73. D. Mariano Aguado.

74. Illmo. Sr. D. Félix Garcia Gomez.

75. Sr. Marqués de la Torrecilla.

76. D. Francisco M. Tubino.

77. D. Manuel Ruiz Higuero.

78. D. Manuel Pastor y Polo.

79. D. Tomás María Mosquera.

8o. D. Ricardo Chacon.

81. Excmo. Sr. Marqués de Sardoal,

82. Excmo. Sr. D. Manuel Maria Hazañas.

83. D. Emilio Castelar.

84. Illmo. Sr. Vizconde del Ponton.

85. D. Cárlos G. de Abaurrea.

86. Excmo. Sr. Marqués de Corvera.

87. D. Nilo María Fabra.

88. Excmo. Sr. D. Luis de Estrada.

89. D. Ricardo Jover.

9o. D. Ángel Echalecu.

91. D. Diego Lopez de Morla.

92. D. Julian de Zugasti y Saenz.

93. Excmo. Sr. Marqués de Aranda.

94. Excmo. Sr. Marqués de Heredia.

95. D. José Carranza y Valle.

96. D. Justo Pelayo Cuesta.

97. D. Ramon Lopez Cano.

98. Excmo. Sr. D. Joaquin Salafranca. 
99. D. Fermin Lasala.

100. Excmo. Sr.Conde de Placencia.

Iо . Excmo. Sr. Duque de Alburquerque.

I02. D. Ramon Miranda.

Io3. Illmo. Sr. D. José Ribero.

104. D. Amós de Escalante.

105. D. Francisco de Paula Acedo.

106. D. Ramon de Campoamor.

107. D. Antonio Cabanilles.

I 08. Sr. Conde de San Julian.

rog. Sr. Conde del Valle de San Juan.

I I 0 . D. Juan Uña.

II . D. Joaquin Maldonado Macanaz.

I I 2. D. Federico Fernandez San Roman.

I 3. D. Lope Gisbert.

114. D. Juan Vilanova.

I 15. D. Manuel Goicoechea.

116. Excmo. Sr. Marqués de Cabriñana.

117. El Ateneo de Madrid.

I 8 . D. Juan Mañé y Flaquer.

I 19. D. Patricio Aguirte de Tejada.

I 20. Excmo. Sr. D. José de Entrala y Perales.

121. D. Fernando de Sola.

122. $111 \mathrm{mo}$. Sr. D. Francisco Barca.

I 23. Excmo. Sr. D. Leopoldo Augusto de Cueto.

124. D. Mariano Vazquez.

125. D. Juan Federico Muntadas.

1 26 . Sr. Conde de Villaverde la Alta.

I 27. Excmo. Sr. D. Eugenio Moreno Lopez.

I 28. D. Cayetano Alberto de la Barrera.

129. Excmo. Sr. D. Manuel Bermudez de Castro

I3o. D. Gerónimo de la Gándara.

I 3 I. D. Cárlos de Haes.

132. D. Antonio Terreros.

I33. D. Cárlos Ramirez de Arellano.

134. D. Manuel Jontoya.

135. La Biblioteca Colombina. 
I36. D. Ricardo de la Vega.

I37. D. Juan de Dios de la Rada y Delgado.

138. D. Eduardo Sanchez y Rubio.

139. La Biblioteca del Senado.

I40. D. Vicente de Soliveres y Miera.

I 41. D. Ramon Sanjuanena y Nadal.

142. D. José de Garnica.

143. La Biblioteca del Ministerio de Ultramar.

144. Excmo. Sr. D. Bonifacio Cortés Llanos.

145. Illmo. Sr. D. Manuel Merelo.

146. Sr. Conde de Alcoy.

147. D. Fernando Nuñez Arenas.

148. D. Adolfo Mentaberri.

149. D. Joaquin Aguado.

I 5o. D. Eduardo Gasset y Mateu.

I5I. D. Manuel Cañete.

152. D. Francisco de Borja Pabon.

153. Excmo. Sr. Marqués de Molins.

154. D. Francisco Bermudez de Sotomayor.

155. D. Eleuterio Gonzalez de la Mota.

I56. D. Francisco Millan y Caro.

157. Excmo. Sr. Marqués de la Merced.

158. D. Manuel R. Zarco del Valle.

159. D. Isidoro Urzaiz.

I6o. D. Fernando Fulgosio.

I6r. D. Rafael Blanco y Criado.

162. Excmo. Sr. Marqués de Vallejo.

163. D. Pedro Gadeo.

I64. D. Lucio Dominguez.

165. Excmo. Sr. D. Luis Gonzalez Brabo.

166. D. José María Cláros.

167. Illmo. Sr. D. Fermin de la Puente Apezechea.

I68. D. Justo Gonzalez Molada.

I69. D. Severo Catalina.

I 7o. D. José Jover y Paroldo.

I 7 . D. Angel Laso de la Vega y Argüelles.

I 72. D. Rafael Jover. 
173. D. Vicente Galiana.

174. D. Salvador de Torres y Aguilar.

175. La Biblioteca de la Real Academia Española.

176. D. Fernando Fernandez de Velasco.

177. D. Ramon Rua Figueroa.

I 78. D. Joaquin Ruiz Cańabate.

179. D. Amalio Ayllon.

I 8o. D. José Sehneidre y Reyes.

181. D. Francisco Morcillo y Leon.

182. D. Juan José Diaz.

I 83. D. Pedro N. Oseñalde.

184. D. Cárlos Susbielas.

I 85. Illmo. Sr. D. Federico Hoppe.

186. D. Manuel Galiano.

I 87. D. José Plazaola.

I88. D. Bonifacio Montejo.

189. D. Damian Menendez Rayon.

19o. D. Antonio Enrique Gomez.

I9r. D. Francisco de Paula Canalejas.

I92. George Ticknor. Esq.

193. Frederic. W. Cosens. Esq.

I 94 . Robert S. Turner. Esq.

195. Sr. Marqués de Pidal

196. Sr. Vizconde de Manzanera.

197. D. Juan de Tro y Ortolano.

198. D. Rafael Sierra.

199. D. José María de Alava.

200. Excmo. Sr. Marqués de Barzanallana.

20I. Excmo. Sr. Conde de Valencia de Don Juan.

202. D. Cárlos Baylly-Bailliére.

203. D. José María Asensio.

204. Real Academia de la Historia.

205. IIlmo. Sr. D. Fernando Balsalobre.

206. Illmo. Sr. D. Salvador de Albacete.

207. Illmo. Sr. D. Juan Valera.

208. Excmo. Sr. D. Gabriel Enriquez.

209. Sr. Conde de Torrepando. 


\section{3}

210. Excmo. Sr. Duque de Gor.

211 . D. Vicente de Lafuente.

2 2. D. Félix María de Urcullu y Zulucta.

213 . D. Francisco de Borja Palomo.

2 I 4. Sr. Marqués de Valdueza.

215. Excmo. Sr. D. José Fariñas.

216 . D. Luis de la Escosura.

217 . D. Jesus Muñoz y Romero.

2 I 8 . Sr. Conde de Agramonte.

2 I9. D. Manuel Cerdá.

220. Biblioteca del Ministerio de Fomento.

221. D. Mariano Bosch y Arroyo.

222. D. José Sancho Rayon.

223. D. Cayetano Manrique.

224. D. Antonio Martin Gamero.

225. Excmo. Sr. Marqués de Casa Loring.

226. Excmo. Sr. D. Adelardo Lopez de Ayala.

227. D. Fernando Arias Saavedra.

228. D. Juan Nepomuceno Jaspe.

229. D. Alfonso Durán.

230. Biblioteca provincial de Toledo.

23 . D. José Santucho y Marcuyo.

232. D. Enrique Suender y Rodriguez.

233. Doctor E. Thebussem.

234. D. Victoriano Palacios. 


\section{JUNTA DE GOBIERNO.}

Presidente. . . . Excmo. Sr, D. Juan Eugenio Hartzenbusch.

Vicepresidente. . D. Cayetano Rosell.

Tesorero. . . . D. Feliciano Ramirez de Arellano.

Contador. . . . . D. Eduardo de Mariátegui.

Secretario primero. D. Gregorio Cruzada Villaamil.

Secretario segundo. D. José María Octavio de Toledo. 



$x$ A

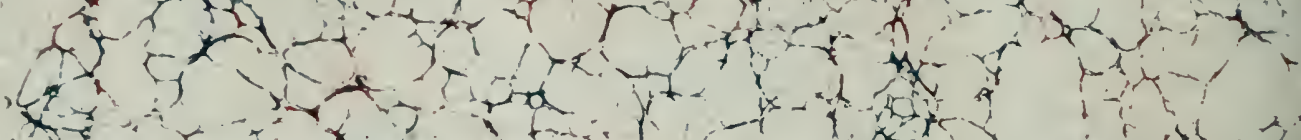

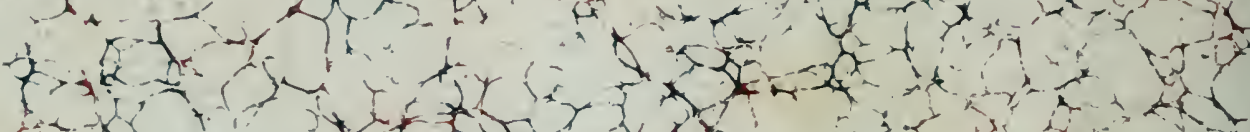

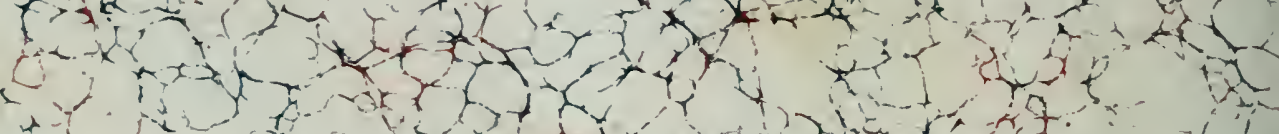

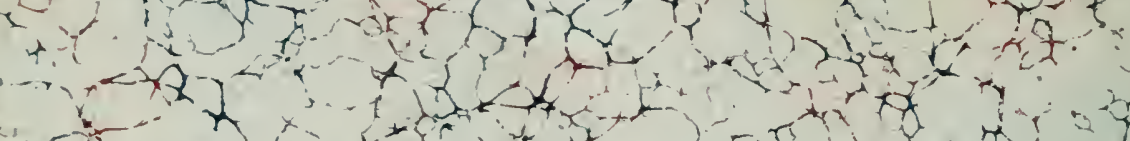

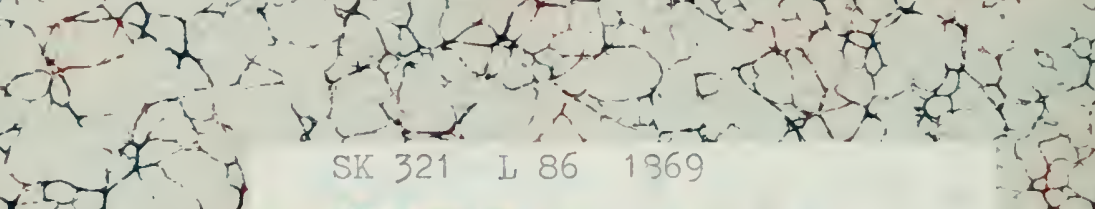

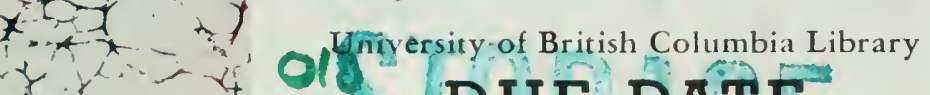
Bollo DUE DATE

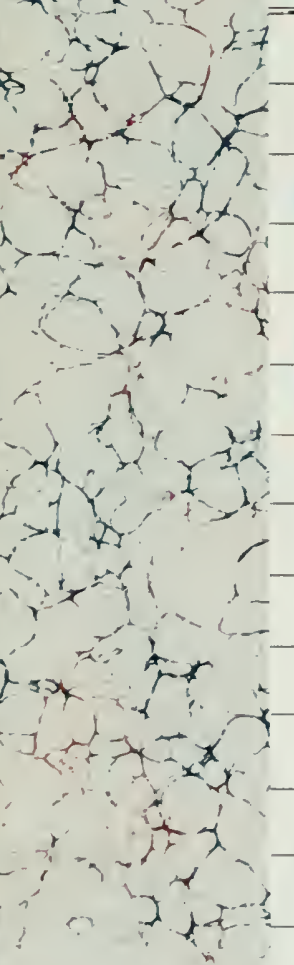

$\therefore x+5$ 6.Y \& \& 52963

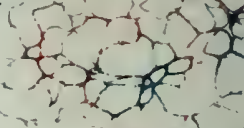
$\rightarrow-1+x$ $+2 x+3$ $x+x, y=$ (7) $+x+2$ 然 - $x+2$ $x+2$ $3+4$ fot 7 torte

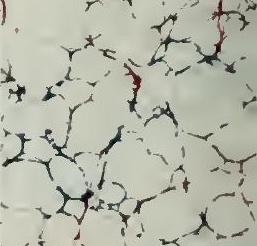

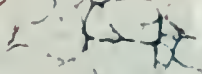
(1)

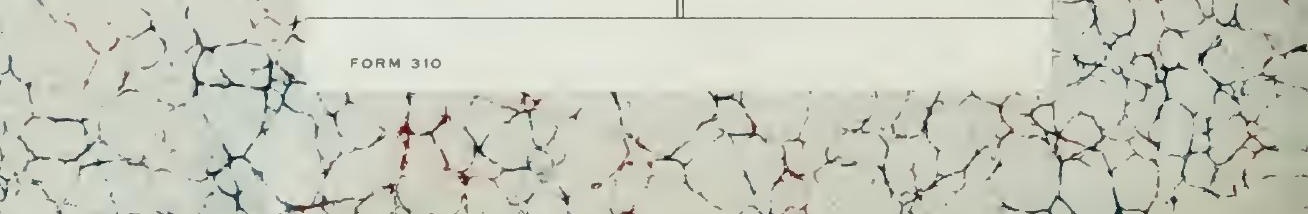

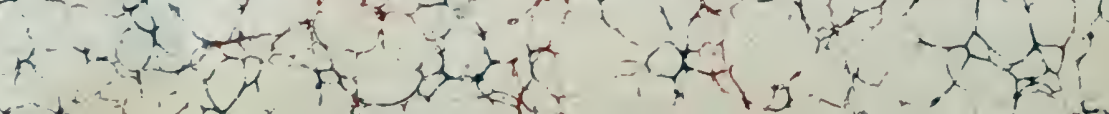


$\frac{x}{4}+4=6$

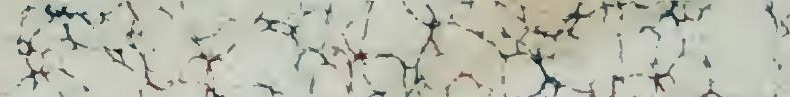
(3) (n)

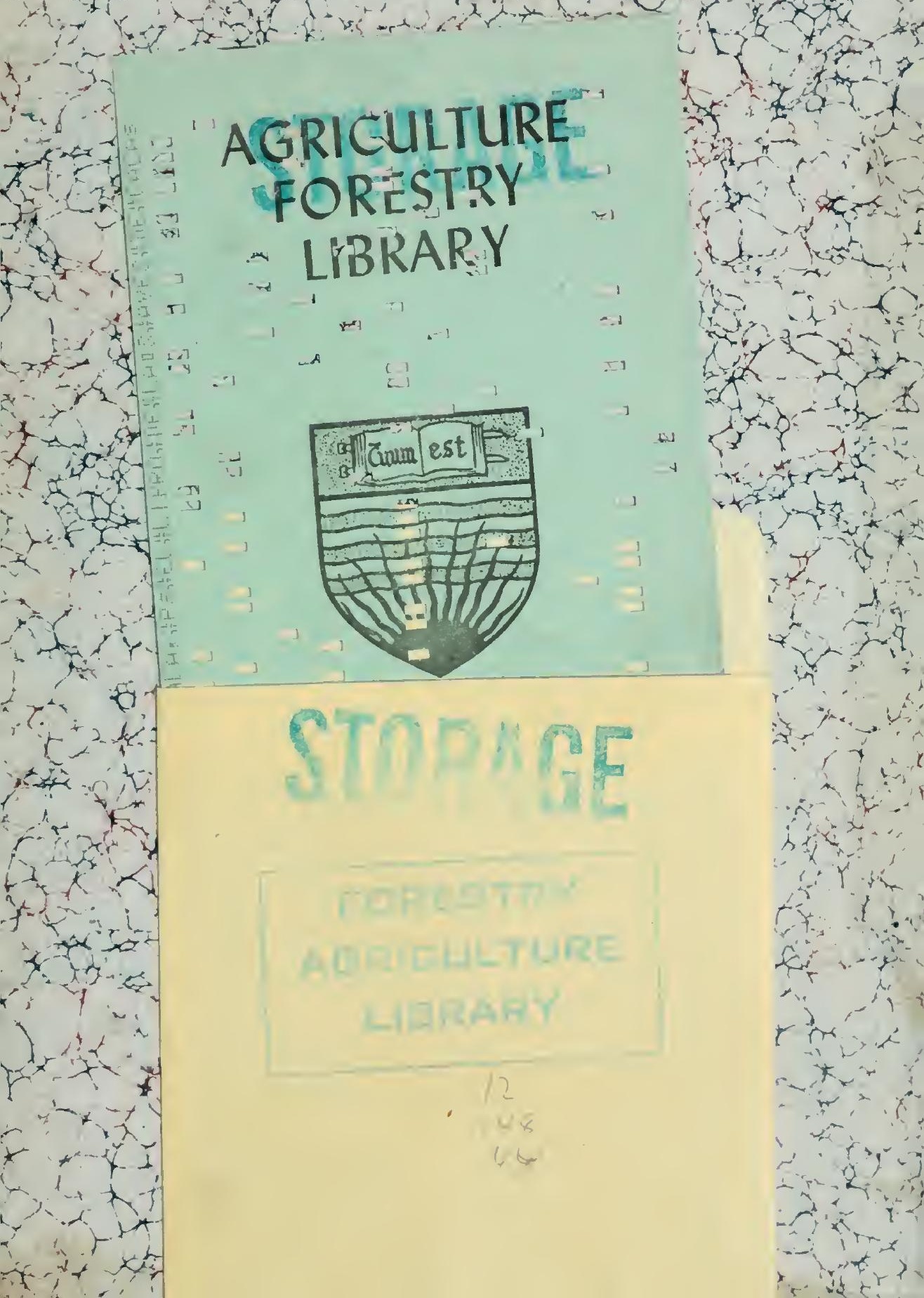


